\title{
Do corporate depositors risk everything for nothing? The importance of deposit relationships, interest rates and bank risk
}

\author{
Daniel Friedmann $^{\#} \quad$ Björn Imbierowicz ${ }^{\ddagger} \quad$ Anthony Saunders* ${ }^{*} \quad$ Sascha Steffen $^{\circ}$
}

\begin{abstract}
We analyze more than 75,000 auctions in which banks bid for firm deposits. In each of these auctions, only the firm observes the banks and their bids and decides where to deposit its funds. Our results show that a bank's risk is irrelevant to firms in their decision, irrespective of its measurement and the economic period. In many cases, firms simply select the highest bidding bank. Our data show that this implies on average the risk of losing $€ 74$ million for a maximum higher interest income of only $€ 1,300$, that is, 0.18 basis points, compared with the worst bid in the auction. Firms only diversify extraordinarily large deposit amounts but also in this case do not account for the individual banks' risk. Our findings argue for moral hazard of firms, which seem to rely on government bailouts of banks and/or central bank interventions. We further observe that also in rather impersonal electronic markets, relationships are an important decision criterion for firms. A stronger deposit relationship with a firm increases a bank's probability to be selected in an auction. Furthermore, it also increases a bank's access to more unsecured deposits from the firm in future periods, including severe crises. Our results reveal that also in markets with high transparency and no switching costs firms base the decision of where to deposit their money on bank relationships as well as the interest rate, but largely disregard bank risk. This has important implications for banks' access to unsecured corporate funding.
\end{abstract}

Keywords: Auctions, Corporate Deposits, Financial Crisis, Banking Crisis, Relationship. JEL classification: D44, G01, G21, G32, L14.

Imbierowicz gratefully acknowledges support from the Center for Financial Frictions (FRIC), grant no. DNRF102.

\# Goethe University Frankfurt, House of Finance, Theodor-W.-Adorno-Platz 3, 60323 Frankfurt (Germany), Email: danielfriedmann@hotmail.com, Tel.: +496979833700.

+ Copenhagen Business School, Finance Department and Center for Financial Frictions (FRIC), Solbjerg Plads 3 , 2000 Frederiksberg (Denmark), Email: bi.fi@cbs.dk, Tel: +45 38153736.

* New York University, Stern School of Business, Department of Finance, John M. Schiff Professor of Finance, 44 West 4th St., New York, NY 10012 (USA), Email: asaunder@stern.nyu.edu, Tel: +1-212-998-0711.

${ }^{\circ}$ University of Mannheim \& ZEW, L7, 1, 68161 Mannheim (Germany), Email: steffen@ @ew.de, Tel: +49 (0)621 1235-140. 


\section{Introduction}

Little is known about how firms select the banks where they deposit their funds, especially their short-term liquidity. This is important from both the firm's and the bank's perspective. Today's continuous liquidity management of firms implies that many firms deposit high amounts of their daily liquidity with differing banks to earn interest income and let it not just sit idle. The postponement of access to this liquidity for only a few days due to for example financial difficulties of a bank could already cause substantial problems to a firm. Most banks rely on continuously obtaining short-term funding. The daily, unsecured, funds from firms' liquidity management are especially interesting for banks because these are often cheaper than in the interbank market. ${ }^{1}$ Additionally, they are especially useful in times when the interbank or secured (repurchase) funding markets are in stress (e.g.; Afonso, Kovner, and Schoar, 2011; Ashcraft, McAndrews, and Skeie, 2011; Gorton and Metrick, 2012; Krishnamurthy, Nagel, and Orlov, 2014; Heider, Hoerova, and Holthausen, 2015). A large strand of literature investigates the matching of banks and firms when a firm applies for a loan at a bank. However, to our knowledge, no study to date investigates if the same patterns also apply in the opposite direction - firms lending money to banks, that is, firm deposits. ${ }^{2}$ Our study tries to fill this gap.

The literature on firm loans shows that the most important determinants for contract characteristics, credit availability and eventually firm real effects are the risk of the firm and the

\footnotetext{
${ }^{1}$ In the following section, we provide more institutional details, which show that in case of bank default the (uninsured) deposits in our study are treated equally to claims of bondholders, while they have the same seniority as long-term and but lower seniority than short-term unsecured interbank transactions. Note that this is in contrast to the US, where uninsured depositors have first claim over other non-deposit claim holders in the event of bank failure, as regulated in the 1993 Depositor Preference Act.

${ }^{2}$ Maybe related the most to our study are Mester et al. (2007) and Gatev et al. (2009) who investigate transaction accounts. However, they focus on the relation between assets and liabilities within banks and less on the matching between firms and banks.
} 
relationship of the firm to the bank. ${ }^{3}$ However, today's daily management of firm liquidity also implies that large amounts of cash are transferred from the firm each day to reduce the cost of holding liquidity (Duchin et al., 2016). Furthermore, especially in crises, firms hoard liquidity to be able to address (potential) shortages in bank loans, with strong effects on investment (Bates, Kahle, and Stulz, 2009; Duchin, Ozbas, and Sensoy, 2009; Bolton, Chen, and Wang, 2013; Campello et al., 2011; Bolton, Wang, and Yang, 2016). These short-term amounts can be very substantial. To preview some of our results, firms offer on average $€ 69$ million in a transaction while the median European non-financial firm in Compustat in 2008 had current assets of $€ 79.1$ million, total liabilities of $€ 91.5$ million and total assets of $€ 165$ million. We do not know the firms' but the banks' identities in our data and observe that our deposit data correspond to about $15 \%$ of banks' current assets. ${ }^{4}$ Given these substantial amounts we hypothesize that comparable patterns as in the loan market should be observable for the matching between banks and firms in the deposit market. In other words, the most important factors, besides the interest rate, should be the risk of the bank and the bank-firm relationship. Especially since the events in the recent financial crisis we expect firms to account for bank risk when depositing large amounts of their liquidity, at least after the default of Lehman Brothers (e.g.; Brunnermeier, 2009; Acharya and Richardson, 2009; Cecchetti, 2009; Kacperczyk, and Schnabl, 2010; Covitz, Liang, and Suarez, 2013).

Our data allow us to investigate why and how firms match with banks in the deposit

\footnotetext{
${ }^{3}$ Bharath et al. (2011) for example show that repeated borrowing from the same lender implies better loan terms such that the loan spread and collateral requirements are lower and the loan amount is larger. Elysiani and Goldberg (2005) and Degryse, Kim, and Ongena (2009) provide nice overviews on the effects of relationship on loan contract characteristics and credit availability.

${ }^{4}$ The data are calculated as the average of the daily assumed deposit amount of each bank using all trading days (including zeros). This average is divided by the bank's end of year current assets as reported on the balance sheet. Regarding firms, we do not know their identity but we know if it is a non-financial firm.
} 
market in a very clean set up. We use data from a trading platform since its initiation. ${ }^{5}$ On this platform, firms are able to offer funds over a certain period at a maturity of their choice. The general offer period is 2 minutes. All banks on the platform observe the deposit offer of the firm and have the possibility to bid an interest rate for it. The firm has the choice to select a bank bid or to select no bid at all. We observe all offers and the corresponding bids together with the outcome. As mentioned before, we do not know firms' identities. However, we have a numerical identifier for each of the firms available and are thereby able to track these and their matching with banks over time. We know the identities of banks and observe the timestamp and information of each of their bids. Our data run from 2005 until mid-2010 with 250,607 observations overall. It includes 61 banks bidding in 75,246 auctions initiated by 192 firms. The average offered deposit amount per auction is $€ 69$ million with a maturity of 7.9 days. In all auctions, only the firm observes the bidding information over the auction period and makes a choice based on it, that is, a bank does not observe the other banks' bids in an auction. Note that the setup of an electronic trading platform implies high transparency and no switching costs and allows us to investigate the selection of banks by firms with sufficient statistical power. Furthermore, the short maturity of deposits implies that our findings are largely independent of interest rate expectations. $^{6}$

Our results show that a very important determinant for a bank bid to be selected by a firm is the price. In more than $84 \%$ of all auctions, firms simply select the highest bidding bank. This is also strongly confirmed in multivariate analyses. In line with our hypotheses, relationships are also an important determinant for bank-firm matching. Our results show that a stronger deposit

\footnotetext{
${ }^{5}$ We provide a detailed explanation of the auction format on the platform in the next section.

${ }^{6} \mathrm{We}$ acknowledge that firms may have more short-term deposits when they expect increasing interest rates in the near future. However, a potentially higher number of auctions in these periods has no direct influence per se on the actual selection of a bank in an auction. Nevertheless, we provide many results where we split the data between different periods implying presumably very different interest rate expectations.
} 
relationship with the bank implies a higher probability that a bank's bid is selected. However, we observe that firms do not base the decision on where to deposit their funds on bank risk. This applies in non-crisis as well as crisis times and even in the immediate aftermath of the default of Lehman Brothers. This might be surprising especially in light of an average amount of $€ 74$ million in auctions where a bank bid is selected and an interest income differential between the highest and the lowest bid in an auction (with an executed trade) of $€ 1,300$. Note that the average CDS spread of the five riskiest banks on the intensive margin in our sample is 100 basis points (bps) with an average value of 259 bps in 2009:Q1. This implies that firms risk the loss of large amounts of their daily liquidity for an economically insignificant higher interest income. This strongly suggests that firms seem to rely on government bailouts of banks and/or central bank interventions in crisis conditions.

We investigate our result regarding firms' disregard of bank risk in more detail below. Our findings show that often not cleanly observable but constant factors between a firm and a bank, such as the firm and bank headquarters being very close to each other, or executives in the bank and the firm having close relationships, do not affect our results. ${ }^{7}$ In addition, we control for specific bank related actions such as a capital increase or a government intervention, by including bank-time fixed effects. Furthermore, we do not observe any effects of a potential interrelation between the bank-firm relationship and a bank's risk. In addition, we also detect no evidence that riskier banks bid higher in auctions or receive lower amounts in subsequent periods in contrast to the findings in the US for brokered deposits (FDIC, 2011).

We verify our findings in various robustness tests. In our main analyses, we measure

\footnotetext{
7 Khan et al. (2015) provide empirical evidence that relations between individual managers affect lending relationships. Furthermore, Degryse, and Ongena (2005) show that loan rates decrease with the distance between the firm and the bank and Giannetti and Laeven (2012) confirm a home bias of lenders especially in crises. Adding a time component to our bank-firm fixed effects leaves our results unchanged.
} 
bank risk by bank CDS spreads over time as well by ranking banks by their CDS spread at the time of an auction within this auction. In a first set of robustness tests, we also employ other measures of bank risk such as bank ratings, non-performing loans, bank leverage or the Z-score of a bank. Furthermore, we differentiate between banks from the GIIPS region (Greece, Ireland, Italy, Portugal and Spain) and those headquartered in other European countries. Additionally, we investigate banks on the intensive margin only, that is, banks that assume deposits both in noncrisis and in crisis times. Finally, we control for banks with a substantial increase in risk in the immediate period prior to the auction. All of our tests confirm that firms disregard bank risk when they select a bank to deposit their funds in doing an auction.

In a second set of robustness tests, we investigate if specific auction and deposit characteristics could be responsible for our findings. We observe that neither extraordinarily high bids in an auction nor differences in deposit maturity or deposit notional amounts change our result of firms' disregard of bank risk in auctions. ${ }^{8}$ However, we find that firms deposit with several banks on days when they have extraordinarily high amounts of liquidity available. A detailed analysis reveals that although funds are split between several banks, the amount per transaction is still almost double the amount of non-split transactions (€87 vs. €50 million). Our previous result of firms' disregard of individual bank risk is again confirmed also when distinguishing between split and non-split transactions. In sum, firms seem to diversify when liquidity is extraordinarily high but disregard individual bank risk.

In a third set of robustness tests, we remove all auctions where the highest bid is selected. Our goal is to specifically investigate firms with a potentially lower price-sensitivity. Also this subsample confirms that bank risk has no impact on the decision of a firm to deposit its funds with a bank while a stronger deposit relationship significantly increases the probability that this

\footnotetext{
${ }^{8}$ Note that we only include deposits with a maturity ranging from overnight to up to 2 years.
} 
bank is chosen. Note that our findings also hold when we differentiate between the frequency of firms entering the deposit trading platform. In addition, we observe that the average strength of the relationship between a bank and a firm does not significantly differ by bank risk as well as not by deposit notional, a natural proxy for firm size. ${ }^{9}$

In the last part of our analysis, we investigate the deposit relationship between a bank and a firm in more detail. We first examine if relationship banks bid higher in auctions. We find that relationship banks often do not bid the highest in an auction. Our results indicate that banks are often able to win auctions while bidding lower, when they have had a prior relationship with the firm. We also analyze the potential relationship benefits of banks. We find that if the average relationship level is higher within an auction, calculated by using all banks' deposit relationship to the firm in this auction, the probability that a deposit is made is higher. Furthermore, we observe that a stronger relationship results in a bank being able to obtain a greater amount of deposit funding from a relationship firm in the subsequent period. Importantly, this is true both in non-crisis and in crisis times. Thus, our results reveal that the availability of unsecured funds increases for a bank when it builds a stronger relationship with a firm.

Our findings are in contrast to the literature on depositor discipline, which argues that depositors discipline banks by requiring higher interest rates for deposits and reducing deposit amounts (e.g.; Park and Peristiani, 1998; Jagtiani and Lemieux, 2000; Martinez Peria and Schmukler, 2001; Goldberg and Hudgins, 2002; Maechler and McDill, 2003; Acharya and Mora, 2015; Bennett, Hwa, and Kwast, 2015; Lamers, 2015). Our data, however, imply that riskier banks do not obtain less unsecured firm deposits and do not have to pay higher interest rates. This suggests that firms rely on bank bailouts and monetary policy interventions as implicit

\footnotetext{
${ }^{9}$ In the loan market, Cole, Goldberg, and White (2004) for example show that large lenders grant larger loans while Khwaja and Mian (2008) provide empirical evidence that $30 \%$ of all banks account for $94 \%$ of total lending.
} 
security for their unsecured short-term deposits. This is in line with the findings of DemirgüçKunt and Huizinga (2004), Cubillas, Fonseca, and Gonzáles (2012), and Berger and Turk-Ariss (2015). Finally, our results in the deposit market are comparable to the relationship literature using firm loans (e.g.; Diamond, 1984, 1991; Haubrich, 1989; Petersen and Rajan, 1994; Cole, 1998; Bharath et al., 2007; Puri, Rocholl, and Steffen, 2011; Bolton, Freixas, and Gambacorta, 2016). We observe that a stronger bank-firm relationship increases the availability of unsecured funding for banks.

The paper proceeds as follows. In the section 2, we describe the trading platform and the deposit auction format in more detail and provide institutional details on claim priority in European banks. In Section 3, we describe the data and provide some descriptive statistics. In Section 4, we investigate selection criteria for firms in auctions, with a special focus on bank risk. The results for the deposit auction related relationship effects between a firm and a bank are discussed in section 5. Section 6 concludes.

\section{Institutional Details}

\subsection{The auction format}

We use data from a European trading platform, which ranks among the three largest platforms in Europe by volume. It was founded in the early 2000's as a multi-product platform and grew substantially over time. Prior to trading, banks and firms agree on a framework agreement. This agreement applies to all of their future trades on the platform.

Firms are able to offer any deposit amount with any maturity on the platform. All banks with a framework agreement with the firm observe that the firm offers a deposit and can bid for the funds. The maximum bidding time in general is two minutes but can be adjusted by the firm prior to the start of the auction. Until the end of this period and briefly afterwards, the firm can 
select a bid based on its preferences. Banks do not observe other banks' bids but can adjust their offer during the bidding period. This implies that banks adjust their bid during the bidding process only idiosyncratically due to e.g. changes in the market interest rate but not in response to other banks' bids. Important to note is that the platform uses so-called "nice quotation". This implies that for every $€ 1$ million that a bank bids for, it has to wait one third of a second. Accordingly, if a bank bids for $€ 30$ million it has to wait for 10 seconds $(30 * 1 / 3)$ before it is allowed to adjust its previous bid. In our analysis, we only include the last bid of a bank in an auction because this is the latest information available to a firm when accepting (or rejecting) an offer.

Appendix A2 shows an example of a deposit auction. This auction is executed on November 14, 2005 at 12:35:58 p.m. The maturity is one day, the notional is $€ 76,200,000$ and six banks bid in this auction. The executed bid is the bank bid where "Status" and "Status of bank bid" both indicate "EXEC", that is, the bid of $2.08 \%$ of Bank2 which is provided on November 14, 2005 at 12:35:34 p.m. is the actual transaction. The bids of the other five banks are not selected by the firm indicated by "LCAN" (list cancel) in the column "Status of Bank Bid”. Interest rates on the platform are quoted using an actual/360 day count convention and transactions are settled on the same day. This implies that the amount of $€ 76,200,000$ in the example in Appendix A2 is transferred on November 14, 2005 to Bank2 and repaid to the firm on November 15, 2005. Note that the numerical firm identifier, which is of course the same for all observations in this auction, is removed from the example.

\subsection{Claim Priority of Deposits in Europe}

It is important for the interpretation of our results to understand the priority of the deposits we include in our analyses in case of default. For this purpose, we discuss in this section 
in more detail the concept of "insured", "collateralized" and "secured" in relation to the deposits in our study. We exclude all deposit transactions below a notional value of $€ 100,000$ in our analyses, that is, our data include only uninsured deposits, which are not covered by deposit insurance. Furthermore, these deposits are also not collateralized by specific assets of the bank. However, the explanation if the funds are unsecured is less straightforward as the assets of a bank will be liquidated in case of default and distributed to creditors according to a given priority structure. Accordingly, the bank's assets secure the deposits, however, the deposits' claim priority in case of default matters for this.

In the US, the 1993 Depositor Preference Act (called "Omnibus Budget Reconciliation Act") gives uninsured domestic depositors first claim on the assets of a failed bank over other bank claim holders in the event of bank failure. Thus, these depositors have priority over foreign deposits (that is, deposits payable outside the US), bondholders and interbank funds. In short, uninsured depositors hold "more secured" funds than other claim holders do.

The regulation in Europe regarding claim priority is becoming consistent among countries only since 2015, when the Bank Recovery and Resolution Directive (2014/59/EU) was initiated to secure a minimum harmonization of rules and powers for the recovery and resolution of financial institutions. For an illustration of claim priority in the period before, especially the period 2005 to 2010, which is our observation period, we use the case of Germany as an example. For a German bank, the cascade of losses, and therefore the "inverted claim priority", in this period is as follows:

i. $\quad$ shares and other instruments of Common Equity Tier 1

ii. additional Tier 1 instruments, such as unsecured unlimited subordinated bonds or silent participations with a conversion clause 
iii. instruments of Tier 2, such as subordinated loans or participation rights

iv. unsecured subordinated liabilities that do not meet the requirements of additional Tier 1 and Tier 2 instruments

v. unsecured senior liabilities, such as loans from other banks, bonds, and corporate deposits greater than $€ 100,000$

vi. preferential deposits, such as deposits of private individuals as well as small and medium sized enterprises (SME) greater than $€ 100,000$

Accordingly, the deposits analyzed in our study are included in v. While i. to iii. are considered to be regulatory capital, the remainder is used for bail-in in case of a default of a bank following the ranking above. Accordingly, the corporate deposits that are analyzed in this paper are junior to deposits of SME firms ${ }^{10}$ while they have the same seniority as bank loans. It is important to note that the latter only applies to bank loans with a maturity of at least one week because refinancing interbank loans, that is, interbank liabilities with an initial maturity of less than 7 days, are excluded from this loss cascade. Accordingly, the uninsured and uncollateralized deposits we investigate in our analyses have the same priority as bondholders and longer-term interbank deposits but are junior to short-term interbank deposits and deposits of SMEs.

The claim priority of the relevant corporate deposits is rather comparable among countries in the European Union during the respective timeframe. Briefly investigating also the creditor hierarchy in the UK we observe that losses are incurred first by shareholders, then by any interest incurred post insolvency, followed by unsecured subordinated creditors, such as subordinated bondholders, and finally by unsecured senior creditors, such as bondholders and

\footnotetext{
${ }^{10}$ Note that we are not able to exactly classify the deposits in our study without restriction because we do not have the firms' identities. The average notional amount of $€ 74$ million per actual transaction, however, provides us with confidence that the firms in our sample are rather large.
} 
corporate deposits greater than $£ 85,000$. Accordingly, the rank of corporate deposits is rather similar across European countries.

\section{Data}

\subsection{Sample Selection}

We investigate data from a deposit trading platform on the transaction-level from 2005 until mid-2010 where banks bid for offered deposits of firms. The maturity of these deposits ranges from 1 day to 2 years. We include only Euro-denominated deposits and eliminate all auctions with a notional below $€ 100,000$ and above $€ 500$ million. ${ }^{11}$ We exclude all transactions where only one bank bids for a firm deposit.

The data include a unique numerical identifier for each depositing firm that allows us to distinguish between depositors and track these over time. We know the bidding banks' names and collect annual bank-specific accounting variables from Bankscope and match these (with a one year lag) to each deposit transaction.

We use two measures for banks' risk, which are both based on banks' credit default swap (CDS) spreads with a five-year maturity from Credit Market Analysis (CMA). The first measure bank risk includes a bank's CDS spread at the end of the previous trading day. The second measure bank risk - within auction ranks all banks in an auction according to their CDS spread from low to high risk. An example of this is provided in Appendix A3. The measure is calculated

\footnotetext{
${ }^{11}$ Both of these extreme cases are very uncommon on the platform. We also eliminate all "special" cases regarding interest rates from our analyses. One example of these might be auctions where banks bid a negative interest rate. This can happen when a bank provides quotes automatically - in this case, the bank program might use the interest rate from the interbank market and deduct a margin for the bank which is the final quote provided to the firm. Another example for a "special" case are highly irregular bank quotes within an auction such as $1 \mathrm{bps}$. A reason for this might be that the bank is able to chat with the firm only after having provided a bid to this firm. Note that our data ends in mid-2010 and includes only Euro-denominated transactions, that is, an interest rate of 1 bps or even negative interest rates are very unlikely. We also do not observe one case where any of these "special" bids is accepted by a firm.
} 
as one plus the logarithm of the rank of the bank when ranking banks from low risk to high risk using their CDS spread at the end of the previous trading day. For this measure, we require that we have a CDS spread available for all banks in the auction. This measure allows us to control for the bank risk choice which is actually available to a firm within an auction.

All variables are described in Appendix A1. The final dataset includes 61 banks bidding in 75,246 auctions initiated by 193 firms with overall 250,607 observations.

\subsection{Descriptive Statistics}

The data run from January 3, 2005 until June 30, 2010. Table 1 reports in Panel A descriptive statistics on the deposit transactions. It shows that the 192 firms included in our data on average initiate 3,420 auctions per quarter, of which $64.9 \%$ result in an actual deposit transaction and where in $15.9 \%$ of these the firm does not select the highest bid. This implies that in $84.1 \%$ of all auctions the highest bid is selected and Table 1 shows that there is only a small variation over time. The average firm in our data sample initiates 61 auctions in a quarter and offers $€ 69$ million per auction with a maturity of 7.9 days. Table 1 shows that actual transactions, i.e. auctions where a bank bid is selected by the firm, have a slightly higher notional amount of $€ 74$ million with a maturity of 6 days.

Panel A also shows that the 61 banks in our data set bid together 11,391 times per quarter, with an individual bank bidding on average 325 times in a quarter. ${ }^{12}$ Firms can in general select between 3.3 banks' bids. The average deposit interest rate paid by a bank is 229 bps. Table 1 Panel A shows that this rate strongly decreased towards the end of our sample period. Panel A also shows the growth of the trading platform over time reflected in the increase

\footnotetext{
${ }^{12}$ Note that the actual number of bank bids is much higher in our initial data set but we only include the last bid of a bank in each auction, as explained earlier.
} 
of the number of firms and banks and the corresponding quarterly number of auctions and bank bids.

Panel B of Table 1 reports bank characteristics measured in real terms with 2005 as the base year. It shows that the average bank in our sample has an asset size of $€ 571$ billion, with a book leverage of $95.9 \%$, a return on equity of $7.0 \%$ and a negative asset growth over our sample period of $1.6 \%$. It also has an interest rate margin of $1.1 \%, 2.7 \%$ non-performing loans, and $18.8 \%$ off-balance sheet exposure. The average 5-year bank CDS spread is 78 bps over our sample period.

[Insert Table 1 near here]

Figure 1 depicts information on the deposit volume. It shows in Figure 1A the strong growth of the deposit platform in general with traded deposits increasing from $€ 128$ billion per quarter in 2005 to about $€ 330$ billion per quarter in 2010 . Remember that the platform was founded only in the early 2000's. As mentioned earlier, we do not know the firms' but the banks' identities in our data and observe that our deposit data correspond to about $15 \%$ of banks' current assets. Figure 1B reveals that the average deposit amount per transaction slightly decreases from 2005 until 2008 but remains stable since then at about $€ 64$ million.

[Insert Figure 1 near here]

To ensure that our data reflect a standard market, which allows us to draw general conclusions, we compare the interest rate paid for the deposits on our trading platform with the 1-week EURIBOR (Euro InterBank Offered Rate). The latter is calculated by the European Money Markets Institute (EMMI) as the average of the reported interbank interest rate of several (currently 21) banks, after winsorizing at the $15^{\text {th }}$ and $85^{\text {th }}$ percentile. Figure 2 shows that both rates are comparable, with firm deposit rates in most periods being slightly below the interbank 
interest rate.

[Insert Figure 2 near here]

\section{Selection Criteria in Auctions}

\subsection{General Selection Criteria in Auctions}

In this sub-section, we analyze firm selection criteria in auctions. For this purpose, we define an indicator variable which is one when a bank is selected in an auction. ${ }^{13}$ We regress this variable on bank risk, a variable indicating the highest bid in an auction, relationship as well as further transaction and bank characteristics, the latter measured via accounting variables. The relationship between a bank and a firm is calculated on the trading platform-level by the number of trades (deposited amount) between the firm and the bank over the last year divided by the total number of trades (total deposited amount) of this firm over the last year, following for example Bosch and Steffen (2011), Bharath et al. (2011), and Adam and Streitz (2016). We furthermore include a dummy variable for the first bank bid in an auction to control for a potential impatience of firms' and the log of the number of bidding banks in the auction. ${ }^{14}$ In all regressions, we use heteroscedasticity-robust standard errors clustered at the bank level.

[Insert Table 2 near here]

Panel A of Table 2 confirms our earlier descriptive finding that firms are more likely to

\footnotetext{
${ }^{13}$ In general, this would argue for non-linear regression models. However, in a second step we include several fixed effects for identification. We are concerned about the incidental parameters problem in non-linear regressions in the latter case (e.g.; Greene, 2004) and therefore use OLS regressions in all analyses. In further robustness tests, we also implement an alternative approach comparable to Drucker and Puri (2005) or Bharath et al. (2007) in their analysis of firm loans which they introduce because of the unavailability of all actual bank offers to the firms. Here, we include all banks in an auction which are potentially available to a firm. While this procedure substantially increases the total number of observations it does not change any of our results.

${ }^{14}$ Note that this variable is the same for all observations in an auction and proxies for a purely technical effect, that is, the more banks are bidding in an auction the less likely it is on average that an individual offer is selected. In simple words, this variable is a sanity check of the regression model. In robustness tests, we run all regressions excluding the variable. The results are the same.
} 
select the highest bid in an auction. The coefficient indicates that the highest bidding bank in a deposit auction has an about 45 percentage points higher probability to be selected. Furthermore, Panel A shows that bank risk has no effect on the probability of a bank to be selected by a firm. This holds for bank risk in general, measured via bank CDS spreads, as well as for bank risk with auction, ranking banks in the auction according to their risk, as shown in our illustrative example in Appendix A3. Note that the number of observations decreases by roughly $50 \%$ in the latter case because we require all banks in an auction to have a CDS spread available for our ranking. ${ }^{15}$ Table 2 Panel A also shows that a stronger deposit relationship of a bank with a firm increases the probability that the firm selects the bid of this bank. Bank-specific accounting variables do not appear to have a significant and consistent effect on the selection decision.

The next part of our analyses addresses further factors which might have an influence on our results. Besides idiosyncratic specifics of banks and firms, it might also be the case that longterm factors, such as the headquarters being very close to each other, or executives in the bank and the firm having a close relationship, have an effect on our results. We therefore incorporate bank-firm fixed effects. ${ }^{16}$ Furthermore, we address the potential impact of specific actions of and for a bank in certain periods, such as capital increases or government interventions, by including bank-time fixed effects. ${ }^{17}$ Panel B of Table 2 shows the results. It confirms our prior findings. The likelihood to be selected by a firm increases for a bank in a deposit auction when it bids highest and when it has a stronger relationship with the firm. In contrast, firms disregard bank

\footnotetext{
${ }^{15}$ In further tests, not shown for brevity, we also run all regressions using our general bank risk variable and including only auctions where all banks in an auction have a CDS spread available. The results are very comparable. ${ }^{16}$ Note that these fixed effects to some extent also control for a long-term lending relationship between the firm and the bank, for which we cannot account directly because we do not have the identities of firms. Loans are often rolled-over between firms and banks. This suggests a rather stable lending relationship between a firm and a bank over long periods. For example, Bharath et al. (2011) find that the probability of roll-over is $42 \%$ for relationship lenders.

${ }^{17}$ In these regressions, we include the quarter as the time variable. In our Online Appendix, we also provide results for all tables which include fixed effects in our analyses with month as the measure of time. It shows that results are virtually the same.
} 
risk, in general as well as on the auction-level.

In addition to these effects, it might be that only the events of the financial crisis increased the awareness of firms that some banks bidding in the auctions face financial difficulties. This might explain firms' disregard for bank risk (as measured by CDS spreads) when we investigate the entire sample period. We therefore include in Panel C only the period of the financial crisis, that is, data from August 8, 2007 until the end of our sample in 2010:Q2. This subsample provides further empirical evidence that firms have a higher likelihood to select the highest bidding bank in an auction as well as a bank with a strong relationship with the firm, irrespective of the bank's risk. We investigate this further and include only the six months after September 15, 2008 until March 15, 2009, which is the immediate period after the default of Lehman Brothers. This default was intensely discussed in public worldwide and might have been a signal to firms that banks are not default-free. In other words, it might have increased firms' awareness of banks' risk especially when depositing unsecured deposits. The results in Panel D in Table 2 reveal that this is not the case. Bank risk remains insignificant in explaining bank selection. In this crisis period bidding highest and having a strong deposit relationship increases a bank's probability of being selected. A potential explanation for these findings is the government and central bank interventions in the immediate aftermath of the Lehman default with the intention to calm the markets again. ${ }^{18}$ Our results suggest that regulators were also supporting the risk taking of large corporations via implicit guarantees in the deposit market against large bank failures.

Figure $3 \mathrm{~A}$ shows the average difference between the best and the worst bid in an auction, using all auctions where a bid is selected. It reveals that the interest income lost by selecting a

\footnotetext{
${ }^{18}$ The examples are manifold. While some politicians and journalists called on the FED to allow for financial institutions to fail, central banks around the world immediately implemented rescue packages (e.g.; Bernanke, 2009; Cecchetti, 2009; Sarkar, 2009; European Central Bank, 2010; Kowalski and Shachmurove, 2014).
} 
worse than the highest bid is economically very small. Even at the height of the financial crisis in 2009 , the average interest income lost by not selecting the highest but the worst bid in an auction was only $€ 2,859$ or 0.39 bps. On average, firms would have a lower interest income of only $€ 1,300$ by selecting the lowest bid and not the highest bid in an auction. In other words, firms risk on average $€ 74$ million of their liquidity for an interest income differential of less than 1 basis point. ${ }^{19}$ In Figure $3 \mathrm{~B}$ we investigate the frequency of the highest bid being selected in an auction, the second highest bid being selected, etc. This figure confirms our result that firms have a very strong preference for selecting the highest interest rate in an auction. In addition, the frequency of selecting a lower bid monotonically decreases as interest rate decrease. These results strongly suggests that firms rely on government bailouts of banks and central bank interventions disregarding bank risk and focusing on the deposit interest rate.

[Insert Figure 3 near here]

In the final analysis in this sub-section, we investigate the potential joint influence on the firm's selection decision of the relationship between a firm and a bank and the bank's risk. We thus account for the possibility that a riskier bank might build a stronger deposit relationship with a firm. This could bias our results if our relationship variable proxies for the joint effect of deposit relationships and risk. In Table 3, we therefore include an interaction term for the bankfirm deposit relationship and a bank’s risk, together with bank fixed effects.

\section{[Insert Table 3 near here]}

Table 3 shows no potential joint influence of relationship and bank risk on the selection decision of firms. The interaction term is insignificant in all specifications. Table 3 provides

\footnotetext{
${ }^{19}$ As mentioned before, the platform uses a 30/360 day count convention. We calculate the potential interest income for each bid therefore by dividing the interest rate in our data by 360 and multiplying this with the maturity in days and the notional of the deposit. Note that the numbers here are still very conservative. Investigating the difference between the highest and the lowest bid assumes the extreme case of high-risk banks bidding highest and low-risk banks bidding low. We investigate if this is actually the case later on.
} 
further empirical evidence that banks which bid highest in an auction as well as having a deposit relationship have a higher probability to be selected in the auction. Bank risk is insignificant also in these specifications. Columns V to VIII provide further support that this holds also in financial crisis times.

\subsection{Robustness}

In this sub-section, we investigate the robustness of our results. We first focus on an alternative measurement of bank risk using different proxy variables and the geographical region of banks. Thereafter, we investigate banks on the intensive margin and those which experience a strong increase in risk over a short period of time. This is followed by a more detailed analysis of certain deposit characteristics, specifically the effects of extremely high bank bids, deposit maturity and deposit notional. Thereafter, we analyze if firms diversify their deposits. Finally, we investigate selection criteria of firms when they do not select the highest bid.

\subsubsection{Bank Risk}

In the previous section of the paper, we measured bank risk using banks' 5-year CDS spreads (with a one day lag). Although these are the timely indicators of banks' current risk, firms might base their decision on other variables, such as the accounting statements of banks or bank ratings. In addition, CDS spreads may be noisy indicators if they are infrequently traded. We therefore incorporate several other measures of bank risk. With respect to ratings, we use a bank's long-term issuer rating from Moody's as well as within an auction, resembling our ranking of banks by their risk as shown in Appendix A3. Accordingly, if three banks with a rating of Aaa, Aa2, and A1, respectively, bid in one auction they are ranked in the same order 
and the variable Bank risk - within auction (rating) includes their rank plus one logarithmized, that is the values $0.69,1.10$ and $1.39(\ln (\operatorname{rank}+1))$. For Bank risk (rating) we convert Moody's rating into numerical measures which range from zero to 21 , with 21 assigned to a Aaa rating. With respect to bank accounting information, we incorporate the ratio of a bank's nonperforming loans (NPL) to its total loan portfolio, the leverage of a bank measured by the ratio of liabilities to total assets, and the logarithm of the bank's Z-score. The latter is calculated as the sum of the bank's return on assets and the ratio of total equity to total assets divided by the standard deviation of the return on assets. We use the last 10 years for the derivation of the latter, that is, data starting in 1995. We take the logarithm due to its high skewness (e.g.; Laeven and Levine, 2009). Table 4 shows the results.

\section{[Insert Table 4 near here]}

Table 4 reveals that our prior results are robust to alternative measures of bank risk. Indeed, firms seem to be more likely to select a riskier bank when we use NPL as our measure of bank risk in columns VII to IX. All regression models in Table 4 also confirm that firms are more likely to select the highest bid in an auction. The results furthermore indicate that banks with stronger deposit relationships with a firm have a higher probability of being selected in an auction. These findings are robust to bank-firm as well as to time fixed effects.

We further differentiate between banks' risk using the geographical origin of banks. We define an indicator variable that is one if a bank's headquarter is in Greece, Ireland, Italy, Portugal and Spain (GIIPS bank) and zero otherwise and include it in our regressions. Furthermore, we also interact this variable with our two main bank risk measures based on bank CDS spreads. The interaction term of GIIPS and bank risk allows us to investigate if firms pay more attention to the risk of GIIPS banks only. Table 5 reports our findings. 


\section{[Insert Table 5 near here]}

Panel A of Table 5 shows that the geographical origin of the banks in our sample has no effect on the results over our sample period. If anything, we are able to observe that firms are more likely to select a GIIPS bank. In Panel B of Table 5 we include only the global financial crisis from August 2007 until mid-2010. It confirms the results for the overall sample period. Even in the crisis, firms were more likely to select the highest bid in an auction and to have a higher probability of selecting banks with a stronger deposit relationship. Note that in both Panels A and B of Table 5 GIIPS banks are neither more nor less likely to be selected by firms when they bid highest in an auction, as shown by the interaction term of GIIPS bank and the highest bid variable.

In the next set of our robustness tests, we investigate only banks that utilized the deposit platform over the whole sample period. We thus ensure that we are comparing the same set of banks over our entire sample period. Panel A in Table 6 displays that 37 out of our overall 61 banks participated in the trading platform in both the period prior to as well as during the financial crisis. It also shows that these 37 banks account for more than $96 \%$ of all observations. Using only these banks in our regression models, Panel B of Table 6 does not reveal any differences to our earlier results.

\section{[Insert Table 6 near here]}

Finally, we analyze whether firms become more aware of a strong increase in bank risk in certain periods. We calculate the median weekly (quarterly) percentage change of CDS spreads of all our sample banks. Based on this we define a dummy variable which is one when the percentage change of a bank's CDS spread is more than 5 percentage points above this median value and zero otherwise. Thus, the variable measures a bank's increase in risk relative to the 
banking market overall. We also define two additional dummy variables based on absolute CDS values, which are one when the weekly (quarterly) CDS spread of a bank increases by more than $20 \%$ and $70 \%$, respectively. Table 7 shows the results including each of these dummy variables in a separate regression over our entire sample period as well as for the global financial crisis only. It confirms our previous findings and reveals that also banks which experience a substantial increase in risk over a short period do not have a lower probability to be selected by firms.

\section{[Insert Table 7 near here]}

In all our robustness tests, we observe that firms do not incorporate the risk of banks when placing their uninsured and unsecured deposits. Instead, they only focus on the highest bid in an auction as well as the relationship to the bank. Our analyses indicate firms have enjoyed and exploit implicit guarantees from government bailouts and/or interventions irrespective of the bank risk measure used.

\subsubsection{Deposit Characteristics}

We are also interested if specific deposit characteristics have an influence on our results. It might be the case that our variable Highest bid of auction is driven by some extremely high bids. To test this, we only use auctions with at least three bidding banks and define an indicator variable which is one if the highest bank bid is $50 \%$ above the median interest rate of all bids in the auction. Table 8 Panel A shows the results.

\section{[Insert Table 8 near here]}

Table 8 Panel A reveals that firms focus on the highest bid in the auction in general, with the coefficient for the latter being again significant at the $1 \%$ level in all specifications. These results confirm that firms' preference for the highest interest rate in an auction applies in a 
general setting and is not only related to extraordinarily high bids of banks. Furthermore, our result of firms' disregard of banks' risk as well as a stronger relationship increasing the probability to be selected are also confirmed in this setup.

Another factor which might affect our findings is a deposit's maturity. While some firms might be insensitive to bank risk when depositing overnight it could be that bank risk is important for deposits of longer maturity. We therefore subdivide our sample into deposits with a maturity of only 1 day and those with a maturity of more than 5 days. Note that the maximum maturity we include in our sample is one year. Table 8 Panel B shows the results for both cases.

It illustrates that deposit maturity has no effect on our main results. Irrespective of whether firms deposit for only 1 day or longer than 5 days there is a higher probability of firm's selecting the highest bid in an auction as well as the bank with a stronger deposit relationship to the firm. In contrast, bank risk does not have an effect on the probability to be selected in a deposit auction for overnight deposits. When we investigate deposits with a maturity longer than 5 days we even observe in some specifications that firms seem to be more likely to select riskier banks. In addition, Panel $\mathrm{B}$ indicates that the highest bid in the auction is even more important to firms when depositing longer-term with a coefficient of about $67 \%$ compared with a value of only about $37 \%$ for overnight deposits. In contrast, relationships seem to be especially important to firms when depositing overnight where the coefficient has a value of about $65 \%$ compared with only $16 \%$ for deposits with longer maturity. These data suggest that many firms roll over their overnight deposits with the same bank while for longer maturities, the main variable driving selection is the most rate offered.

Finally, we investigate if effects differ according to deposit size. In Panel C of Table 8, we divide our data into auctions with a notional amount of up to $€ 100$ million and those larger 
than $€ 100$ million. Panel C shows no differences from our prior results, that is firms select banks based on relationships and the highest bid while disregarding bank risk, irrespective of the deposit size.

\subsubsection{Diversification of Deposits}

Our results in the previous sections indicate that firms disregard individual bank risk when placing their deposits. In this section, we investigate if firms manage risk through diversification. We do not know if firms deliberately diversify their liquidity and therefore have to rely on indications in our data. We define an auction as a split deposit when the same firm places a deposit with another bank on the same day. Panel A in Table 9 investigates differences between split and non-split deposits descriptively on the transaction level. It shows that with our definition two-thirds of our sample are split deposits. In $82 \%$ of these the firm selects the highest bid compared with $87.5 \%$ in non-split deposits. Panel A reveals that the notional amount per transaction is $€ 87.2$ million and therefore much larger than in non-split deposits although the total daily amount is split over several banks. We observe that on average firms split deposits over 3.45 different banks, that is, firms deposit in total $€ 300$ million $(=3.45 * € 87.2 \mathrm{mn}$.) on days when they split their liquidity. Thus, our data show that firms diversify only large deposit amounts. To puts the initial number of split deposits into perspective - we include 10,254 days when firms split deposits compared with 16,524 firm-days with no split. Panel A also reveals that while individual bank risk is the same between split and non-split deposits, the deposit relationship between the firm and the bank is much higher in non-split deposits. Furthermore, the number of banks bidding for a deposit is slightly higher and the average maturity about half a day shorter. 
[Insert Table 9 near here]

We investigate the probability to select a bank in an auction and divide our sample into split and non-split deposits. The results are shown in Panel B of Table 9. It confirms our previous findings. Firms disregard individual bank risk when placing their unsecured deposits and are more likely to select the highest bid in an auction as well as a bank with a higher deposit relationship. Thus, splitting liquidity on a given day does not change our results. Our variable Bank risk even indicates that riskier banks are in general more likely to be selected by firms in deposit auctions on days when they do not split their funds. Overall, firms seem to diversify when liquidity is very high but this potential diversification does not account for individual bank risk.

\subsubsection{Selection Criteria when the Highest Bid is Not Selected}

In this sub-section, we are interested if the selection criteria differ in auctions where the highest bid is not selected, which occurs in $15.9 \%$ of the sample. We hypothesize that these firms might be more sensitive to bank risk, that is, select the bids of riskier banks less often. Table 10 shows the results for the sub-sample of auctions where firms do not select the highest bid.

$$
\text { [Insert Table } 10 \text { near here] }
$$

Table 10 illustrates that even when firms do not select the highest bid they disregard bank risk. All coefficients for bank risk in general as well as within an auction are insignificant, irrespective if we investigate our entire sample period (column I to IV) or the financial crisis only (columns V to VIII). In contrast, the high coefficients for deposit relationships reveal that these firms seem to have an even stronger preference for depositing with relationship banks. 


\subsubsection{Further Robustness Tests}

In further robustness tests, we investigate whether there exists differences between auctions of firms which frequently utilize the trading platform and those that do not. For this purpose, we count the number of deposit offers on the platform of each firm in each quarter and split the sample using the median number of firm deposit offers in a quarter. We are interested if firms which enter the platform less frequently, have a lower number of bank interest rate bids available that they can choose from. Figure 4A shows a t-statistic of the number of bidding banks in auctions for frequently and less frequently depositing firms over time. It also shows the $95 \%$ interval of the difference in the number of bidding banks between these two groups. With the only exception of 2008:Q2, Figure 4A shows that the number of bidding banks is not significantly different between firms entering the deposit trading platform frequently and those that offer deposits less frequently. Figure 4B follows the same notion but with respect to the deposit interest rate. Both the t-statistic as well as the average difference of interest rates is statistically insignificant over our entire sample period between firms that often deposit on the platform and those that utilize the platform less frequently. These results suggest that neither bank competition nor the offered interest rate differ by depositing frequency of firms. ${ }^{20}$

[Insert Figure 4 near here]

Finally, we examine those bidding banks, which are often not selected. We observe that these banks are unsuccessful in the current quarter because they have a poor relationship with most of the depositing firms and often do not bid the highest in the auctions they participate in.

\footnotetext{
${ }^{20}$ In another set of tests, not shown for brevity, we also investigate if firms differ in their frequency of deposit offers or the number of banks they select on average in a quarter based on their platform age, that is, if they just enter the market, regularly use the market, or exit the deposit platform. We do this to observe if some firms build very strong relationships with banks over time such that they exit our data set and presumably thereafter deposit only directly with these relationship banks. We do neither observe statistical differences in the number of initiated auctions nor the number of selected banks in a quarter between firms of a different age on the platform.
} 
However, when we compare these banks in the subsequent quarter, we find that they become more comparable to the more successful banks on the platform regarding (i) the number of bids in a quarter, (ii) the number of auctions where they bid highest, (iii) the number of firms they provide bids for, and (iv) the amount they are bidding for. Accordingly, banks appear to learn over time with respect to their market behavior. ${ }^{21}$

\section{Deposit Relationships in Auctions}

The results in the previous section show that, besides the highest bid, the relationship between a firm and a bank is a very important factor for firms in their decision of where to deposit their funds. In this section, we investigate this relationship in more detail. First, we are interested if relationship banks differ in their bidding strategy in auctions. Thereafter, we examine potential benefits for banks when they build a relationship with a firm.

\subsection{Bidding of Relationship Banks}

Before we analyze further the effects of the relationship between a firm and a bank we first need to understand how relationships originate in deposit markets. We know from the loan market that banks initially charge lower rates which (often) further decrease for the following loan (Bodenhorn, 2003; Ioannidou and Ongena, 2010; López-Espinosa, Mayordomo, and Moreno, 2016). ${ }^{22}$ Our prior results show that bidding highest in an auction implies a higher probability of being selected. We therefore investigate if relationship banks have a greater probability of bidding highest in an auction, or alternatively whether banks with a low

\footnotetext{
${ }^{21}$ A further concern might be that a potential joint determination of the deposit volume and the interest rate affects results. Acharya et al. (2016) address this concern in deposit auction markets and do neither observe any such effect in subsamples nor in instrumental variable regressions.

${ }^{22}$ Ioannidou and Ongena (2010) show that banks eventually increase these loan rates again which relates to hold-up.
} 
relationship to the depositing firm bid higher so as to increase their relationships in future transactions. For this purpose, we use the sample of all executed bids, that is, actual deposit transactions, and regress an indicator variable, which is one when the highest bid is selected and zero otherwise, on our bank relationship measure, bank risk and further control variables. Table 11 Panel A shows the results without including any fixed effects.

\section{[Insert Table 11 near here]}

The table shows that the intensity of the bank-firm relationship is not related to the probability of bidding highest in an auction. We include bank-firm and bank-time fixed effects in Panel B of Table 11. When doing so, we observe that relationship banks appear to have a lower probability of bidding highest in an auction. The negative coefficient for relationship implies that an increase in the bank-firm relationship results in a higher probability of acceptance of a bank's bid, even though it is less likely to provide the highest bid.

We investigate this finding from another angle and regress a bidders' deposit interest rate spread over the risk-free rate on relationship and control variables. We calculate the spread by subtracting from the bid rate the ECB marginal deposit facility interest rate, in line with Acharya et al. (2016). If relationship banks are able to obtain funding at lower costs (spreads), we should observe this for banks which interact more frequently with a firm. We use all data from the trading platform since its initiation in the beginning of the 2000's and define three variables, indicating whether a bank has interacted with a particular firm between 1 to 100 times, between 101 to 300 times and between 301 to 600 times, and zero otherwise. ${ }^{23}$ Panel $\mathrm{C}$ of Table 11 displays the results. It shows that interacting frequently with a particular firm implies that a bank has a funding cost (spread) advantage when assuming short-term deposits compared with other

\footnotetext{
${ }^{23}$ We discard all observations above 600 interactions between a bank and a firm to avoid potential effects from outliers.
} 
banks. Banks which enter the deposit market on the platform for the first time have to pay 2.8 bps higher interest rates, while the interest rate is 2 bps higher for banks which have interacted with a firm 101 to 300 times. In sum, we observe in Table 11, that relationship banks tend to be able to profit by obtaining unsecured deposit funds from firms at a lower interest rate than nonrelationship banks.

Panels $\mathrm{A}$ to $\mathrm{C}$ in Table 11 also include our bank risk measures. Note that this is an important robustness check to our previous results as riskier banks might be willing to pay higher interest rates. However, all results in Table 11 show that riskier banks do not pay higher interest rates for deposits purchased from the platform. Note that this result is in contrast to the literature on depositor discipline in the U.S. and its effects on interest rates (e.g.; Park and Peristiani, 1998; Martinez Peria and Schmukler, 2001; Jagtiani and Lemieux, 2000; Acharya and Mora, 2015).

\subsection{The Funding Benefits of Relationships}

The last sub-section already shows that relationship banks have a lower probability of bidding highest and that banks which repeatedly interact with firms on the platform obtain funds at lower costs. In this sub-section, we investigate a further potential benefit of relationships, which is deposit fund availability. As has been established many banks faced short-term funding

problems in the financial crisis (e.g.; Kacperczyk and Schnabl, 2010; Acharya, Gale, and Yorulmazer, 2011; Acharya and Skeie, 2011; Afonso, Kovner, and Schoar, 2011; Acharya and Merrouche, 2013). Under such conditions unsecured, short-term, firm deposits are an alternative source of funding. We therefore investigate whether banks have more corporate deposits available when they have stronger relationships with firms.

In a first set of regressions, we investigate the general availability of funds for banks by 
aggregating our data at the auction level. We are interested in the difference between auctions where a bid is selected and those where all bids are discarded (i.e. funds are rationed). Accordingly, we calculate the average risk of all banks in an auction, the average relationship of all banks bidding in this auction, etc., and use these as explanatory variables in regressions of an indicator variable, which is one if an auction results in an accepted bid and zero otherwise. We also include firm and time fixed effects. The results are provided in Table 12 using heteroscedasticity-robust standard errors clustered at the time-level.

\section{[Insert Table 12 near here]}

Table 12 shows that firms are more likely to select a bank bid and make funds available in an auction when its average level of relationships with bidding banks is higher. This indicates that if one or more banks with a strong relationship with a firm participate in an auction, the firm is more likely to deposit its funds in the banking system thus increasing the supply of funds to banks. We furthermore observe that the average level of bank risk does not affect a firm's decision to discard all bids in an auction

In a second set of regressions, we aggregate our data to the bank-firm-quarter level. We are interested whether a bank is able to benefit from a stronger relationship with a firm by obtaining more funding in subsequent periods. For this purpose, we regress the logarithm of the total amount a bank receives from a firm in a quarter on the lagged value of its relationship with the firm and its average risk in the previous quarter (measured by its CDS spread). Panel A of Table 13 shows the results.

\section{[Insert Table 13 near here]}

We observe that building a stronger relationship with a firm results in a bank receiving more short-term funds from this firm in the subsequent quarter. Panel A also shows in columns 
V to VIII that this continues to hold when we only include the global financial crisis period. In addition, it also confirms that bank risk has no effect on a firm's future decision of how much in terms of size to deposit with a bank. ${ }^{24}$

\subsection{Further Robustness Tests}

In a final set of robustness tests, we examine whether relationship effects differ according to bank risk as well as deposit size, a natural proxy for firm size. We are first interested if riskier banks build stronger relationships. Note that this complements our multivariate results in Table 3 where we investigate the joint effect of bank risk and relationships on selection probability. For this purpose, we subdivide our sample into high-risk and low-risk banks using the median value of bank risk in a quarter as threshold. In Figure $5 \mathrm{~A}$, we plot the $25^{\text {th }}$ and the $75^{\text {th }}$ percentile of our relationship measure of these two risk groups over time. ${ }^{25}$ It shows that there are no substantial differences in relationships between high-risk and low-risk banks.

\section{[Insert Figure 5 near here]}

In a second step, we are interested if smaller firms build stronger relationships with banks, similar to the concept of bank-dependency in the loan literature (e.g.; Gertler and Gilchrist, 1994; Chodorow-Reich, 2014). Given that we do not know the identities of firms we use the notional deposit amount as a proxy for firm size. We follow the same notion as in Figure 5A and split firms into small and large firms using the median as threshold. We plot the $25^{\text {th }}$ and $75^{\text {th }}$ percentile of our relationship measure for both size groups in Figure 5B. It provides graphical evidence that firms of different sizes do not build differentially strong relationships

\footnotetext{
${ }^{24}$ We also re-run these regressions on the bank-firm-month level. Furthermore, we calculate the total amount as the sum of all individual deposited amounts times their respective maturity and use the logarithm of it as dependent variable. We show in our Online Appendix that the results are very comparable.

${ }^{25}$ We show results for our relationship measure based on the number of trades. We repeat the test using our relationship measure based on deposit amount, not shown for brevity. The results are the same.
} 
with banks. This suggests that deposit amount, implicitly a proxy for firm size, has no effect on the relationship between a firm and a bank on our deposit trading platform.

\section{Conclusion}

In this paper, we investigate auctions of unsecured short-term deposits where banks bid for funds offered by firms on a trading platform. Our main finding is that firms' disregard bank risk. Neither in good economic periods nor during severe crisis times do firms select banks in an auction based on bank's individual risk. The only indication of risk management is given by firms splitting very large amounts over several banks. However, individual bank risk is also disregarded in this case. In contrast, the most important criterion for firms is the highest bid in an auction. In addition, relationship banks have a higher probability to be selected.

Our results reveal that firms risk very large notional amounts of their liquidity for a negligible amount of higher interest return. However, this appears rational from the firms' perspective. While the financial crisis increased the general awareness of the risks in bank portfolios, politicians, regulators and central banks have intervened in market mechanisms numerous times, and as a result have produced inevitable implicit guarantees to large firms.

Our results also show that banks have incentives to build and maintain relationships to their corporate deposit customers. Although we investigate an electronic trading platform where deposits can be placed with any bidding bank, our data reveal a certain loyalty of firms to their relationship banks. These banks are able to benefit via a higher availability of funds at lower interest rates. Relationships accordingly affect a wide range of financial markets also in times of technological change and remain an exciting area for future research. 


\section{References}

Acharya, Viral V., Douglas Gale, and Tanju Yorulmazer, 2011, Rollover Risk and Market Freezes, The Journal of Finance 66 (4), 1177-1209.

Acharya, Viral V., Björn Imbierowicz, Sascha Steffen, and Daniel Teichmann, 2016, Does the Lack of Financial Stability Impair the Transmission of Monetary Policy?, Working Paper, New York University.

Acharya, Viral V., and Ouarda Merrouche, 2013, Precautionary Hoarding of Liquidity and Interbank Markets: Evidence from the Subprime Crisis, Review of Finance 17 (1), 107160.

Acharya, Viral V., and Nada Mora, 2015, A Crisis of Banks as Liquidity Providers, The Journal of Finance 70 (1), 1-43.

Acharya, Viral V., and Matthew P. Richardson, 2009, Causes of the Financial Crisis, Critical Review 21 (2 \& 3), 195-210.

Acharya, Viral V., and David Skeie, 2011, A model of liquidity hoarding and term premia in inter-bank markets, Journal of Monetary Economics 58 (5), 436-447.

Adam, Tim R., and Daniel Streitz, 2016, Hold-up and the use of performance-sensitive debt, Journal of Financial Intermediation 26, 47-67.

Afonso, Gara, Anna Kovner, and Antoinette Schoar, 2011, Stressed, Not Frozen: The Federal Funds Market in the Financial Crisis, The Journal of Finance 66 (4), 1109-1139.

Ashcraft, Adam, James McAndrews, David Skeie, 2011, Precautionary Reserves and the Interbank Market, Journal of Money, Credit and Banking 43 (2), 311-348.

Bates, Thomas W., Kathleen M. Kahle, and René M. Stulz, 2009, Why Do U.S. Firms Hold So Much More Cash than They Used To?, The Journal of Finance 64 (5), 1985-2021.

Bennett, Rosalind L., Vivian Hwa, and Myron L. Kwast, 2015, Market discipline by bank creditors during the 2008-2010 crisis, Journal of Financial Stability 20, 51-69.

Berger, Allen N., and Rima Turk-Ariss, 2015, Do Depositors Discipline Banks and Did Government Actions During the Recent Crisis Reduce this Discipline? An International Perspective, Journal of Financial Services Research 48 (2), 103-126.

Bernanke, Ben S., 2009, The Crisis and the Policy Response, Speech, Stamp Lecture at the London School of Economics, London, January 13, 2009.

Bharath, Sreedhar T., Sandeep Dahiya, Anthony Saunders, and Anand Srinivasan, 2007, So what do I get? The bank's view of lending relationships, Journal of Financial Economics 85 (2), 368-419.

Bharath, Sreedhar T., Sandeep Dahiya, Anthony Saunders, and Anand Srinivasan, 2011, Lending Relationships and Loan Contract Terms, The Review of Financial Studies 24 (4), 1141-1203.

Bodenhorn, Howard, 2003, Short-Term Loans and Long-Term Relationships: Relationship Lending in Early America, Journal of Money, Credit and Banking 35 (4), 485-505.

Bolton, Patrick, Hui Chen, and Neng Wang, 2013, Market timing, investment, and risk management, Journal of Financial Economics 109 (1), 40-62.

Bolton, Patrick, Xavier Freixas, and Leonardo Gambacorta, 2016, Relationship and Transaction Lending in a Crisis, The Review of Financial Studies.

Bolton, Patrick, Neng Wang, and Jinqiang Yang, 2016, Liquidity and Risk Management: Coordinating Investment and Compensation Policies, Working Paper, Columbia Business School. 
Bosch, Oliver, and Sascha Steffen, 2011, On syndicate composition, corporate structure and the certification effect of credit ratings, Journal of Banking \& Finance 35 (2), 290-299.

Brunnermeier, Markus K., 2009, Deciphering the Liquidity and Credit Crunch 2007-2008, Journal of Economic Perspectives 23 (1), 77-100.

Campello, Murillo, Erasmo Giambona, John R. Graham, and Campbell R. Harvey, 2011, Liquidity Management and Corporate Investment During a Financial Crisis, The Review of Financial Studies 24 (6), 1944-1979.

Cecchetti, Stephen G., 2009, Crisis and Responses: The Federal Reserve in the Early Stages of the Financial Crisis, Journal of Economic Perspectives 23 (1), 51-75.

Chodorow-Reich, Gabriel, 2014, The employment effects of credit market disruptions: Firmlevel evidence from the 2008-9 financial crisis, The Quarterly Journal of Economics 129 (1), 1-59.

Cole, Rebel A., 1998, The importance of relationships to the availability of credit, Journal of Banking \& Finance 22 (6-8), 959-977.

Cole, Rebel A., Lawrence G. Goldberg, and Lawrence J. White, 2004, Cookie Cutter vs. Character: The Micro Structure of Small Business Lending by Large and Small Banks, The Journal of Financial and Quantitative Analysis 39 (2), 227-251.

Covitz, Daniel, Nellie Lang, and Gustavo A. Suarez, 2013, The Evolution of a Financial Crisis: Collapse of the Asset-Backed Commercial Paper Market, The Journal of Finance 68 (3), 815-848.

Cubillas, Elena, Ana Rosa Fonseca, and Francisco González, 2012, Banking crises and market discipline: International evidence, Journal of Banking \& Finance 36 (8), 2285-2298.

Degryse, Hans, Moshe Kim, and Steven Ongena, 2009, Microeconometrics of Banking: Methods, Applications and Results, Oxford University Press.

Degryse, Hans, and Steven Ongena, 2005, Distance, Lending Relationships, and Competition, The Journal of Finance 60 (1), 231-266.

Demirgüç-Kunt, Asli, and Harry Huizinga, 2004, Market discipline and deposit insurance, Journal of Monetary Economics 51 (2), 375-399.

Diamond Douglas W., 1984, Financial Intermediation and Delegated Monitoring, The Review of Economic Studies 51 (3), 393-414.

Diamond, Douglas, 1991, Debt Maturity Structure and Liquidity Risk, The Quarterly Journal of Economics 106(3), 709-737.

Drucker, Steven, and Manju Puri, 2005, On the Benefits of Concurrent Lending and Underwriting, The Journal of Finance 60 (6), 2763-2799.

Duchin, Ran, Thomas Gilbert, Jarrad Harford and Christopher M. Hrdlicka, 2016, Precautionary Savings with Risky Assets: When Cash Is Not Cash, The Journal of Finance, forthcoming.

Duchin, Ran, Oguzhan Ozbas, and Berk A. Sensoy, 2009, Costly external finance, corporate investment, and the subprime mortgage credit crisis, Journal of Financial Economics 97 (3), 418-435.

Elyasiani, Elyas, and Lawrence G. Goldberg, 2005, Relationship lending: a survey of the literature, Journal of Economics and Business 56 (4), 315-330.

European Central Bank, 2010, The ECB's response to the financial crisis, Monthly Bulletin, October 2010, 59-74.

FDIC, 2011, Study on core deposits and brokered deposits - Submitted to Congress pursuant to the Dodd-Frank Wall Street Reform and Consumer Protection Act, www.fdic.gov. 
Gatev, Evan, Til Schuermann, and Philip E. Strahan, 2009, Managing Bank Liquidity Risk: How Deposit-Loan Synergies Vary with Market Conditions, Review of Financial Studies 22(3), 995-1020.

Gertler, Mark, and Simon Gilchrist, 1994, Monetary Policy, Business Cycles, and the Behavior of Small Manufacturing Firms, The Quarterly Journal of Economics 109 (2), 309-340.

Giannetti, Mariassunta, and Luc Laeven, 2012, The flight home effect: Evidence from the syndicated loan market during financial crises, Journal of Financial Economics 104 (1), 23-43.

Goldberg, Lawrence G., and Sylvia C. Hudgins, 2002, Depositor discipline and changing strategies for regulating thrift institutions, Journal of Financial Economics 63 (2), 263274.

Gorton, Gary, and Andrew Metrick, 2012, Who Ran on Repo?, Working Paper, Yale University.

Greene, William, 2004, Fixed effects and bias due to the incidental parameters problem in the tobit model, Econometric Reviews 23 (2), 125-147.

Haubrich, Joseph, 1989, Financial intermediation, delegated monitoring, and long-term relationships, Journal of Banking and Finance 13(1), 9-20.

Heider, Florian, Marie Hoerova, Cornelia Holthausen, 2015, Liquidity hoarding and interbank market spreads: the role of counterparty risk, Journal of Financial Economics 118, 336354.

Ioannidou, Vasso, and Steven Ongena, 2010, "Time for a Change": Loan Conditions and Bank Behavior when Firms Switch Banks, The Journal of Finance 65 (5), 1847-1877.

Jagtiani, Julapa, and Catharine Lemieux, 2000, Market discipline prior to bank failure, Journal of Economics and Business 53 (2-3), 313-324.

Kacperczyk, Marcin, and Philipp Schnabl, 2010, When Safe Proved Risky: Commercial Paper during the Financial Crisis of 2007-2009, Journal of Economic Perspectives 24 (1), 2950 .

Khan, Urooj, Xinlei Li, Christopher D. Williams, Regina Wittenberg Moerman, 2015, CoMigration and the Benefits of Relationships in Bank Lending, Working Paper, Columbia Business School.

Khwaja, Asim Ijaz, and Atif Mian, 2008, Tracing the Impact of Bank Liquidity Shocks: Evidence from an Emerging Market, The American Economic Review 98 (4), 14131442.

Kowalski, Tadeusz, and Yochanan Shachmurove, 2014, The reaction of the U.S. and the European Monetary Union to recent global financial crises, Global Finance Journal 251 (1), 27-47.

Krishnamurthy, Arvind, Stefan Nagel, and Dmitry Orlov, 2014, Sizing Up Repo, The Journal of Finance 69 (6), 2381-2417.

Laeven, Luc, and Ross Levine, 2009, Bank governance, regulation and risk taking, Journal of Financial Economics 93 (2), 259-275.

Lamers, Martien, 2015, Depositor discipline and bank failures in local markets during the financial crisis, SOM Research Reports 15007-EEF.

López-Espinosa, Germán, Sergio Mayordomo, and Antonio Moreno, 2016, When Does Relationship Lending Start to Pay?, Working Paper, Universidad de Navarra.

Maechler, Andrea M., and Kathleen M. McDill, 2003, Dynamic Depositor Discipline in US Banks, Journal of Banking \& Finance 30 (7), 1871-1898. 
Martinez Peria, Maria S., and Sergio S. Schmukler, 2001, Do depositors punish banks for bad behavior? Market discipline, deposit insurance, and banking crises, The Journal of Finance 56 (3), 1029-1051.

Mester, Loretta J, Leonard I. Nakamura, and Micheline Renault, 2007, Transactions Accounts and Loan Monitoring, Review of Financial Studies 20(3), 529-556.

Park, Sangkyun, and Stavros Peristiani, 1998, Market Discipline by Thrift Depositors, Journal of Money, Credit and Banking 30 (3), 347-364.

Petersen, Mitchell A., and Raghuram G. Rajan, The Benefits of Lending Relationships: Evidence from Small Business Data, The Journal of Finance 49 (1), 3-37.

Puri, Manju, Jörg Rocholl, and Sascha Steffen, 2011, Global retail lending in the aftermath of the US financial crisis: Distinguishing between supply and demand effects, Journal of Financial Economics 100 (3), 556-578.

Sarkar, Asani, 2009, Liquidity risk, credit risk, and the Federal Reserve's responses to the crisis, FRB of New York Staff Report No. 389. 


\section{Figure 1}

\section{Deposit Volume}

The figure shows the volume of deposits provided by firms on the platform from January 2005 to June 2010. Figure 1A depicts the total deposited amount per quarter using all deposit transactions. Figure 1B shows the average notional deposit amount on the auction-level using all auctions.

\section{Panel A: Notional deposit amount per quarter $(€$ bn)}

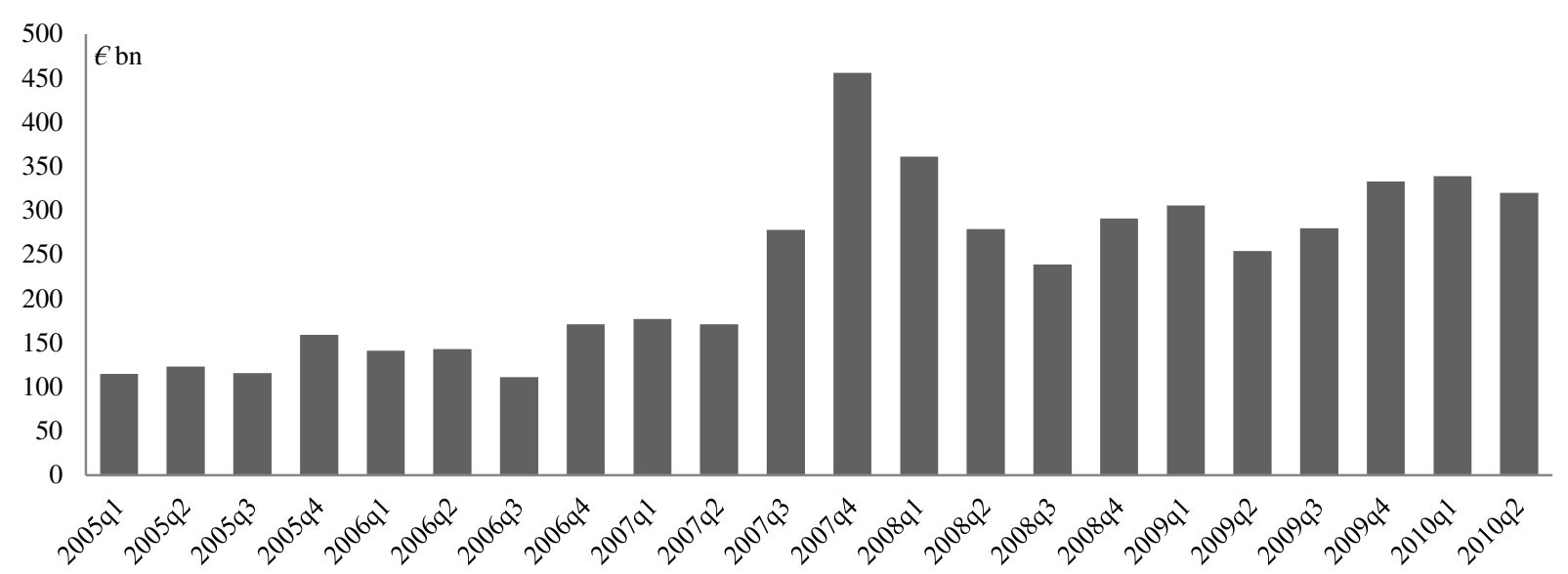

Panel B: Notional deposit amount per auction $(€ \mathrm{~m})$

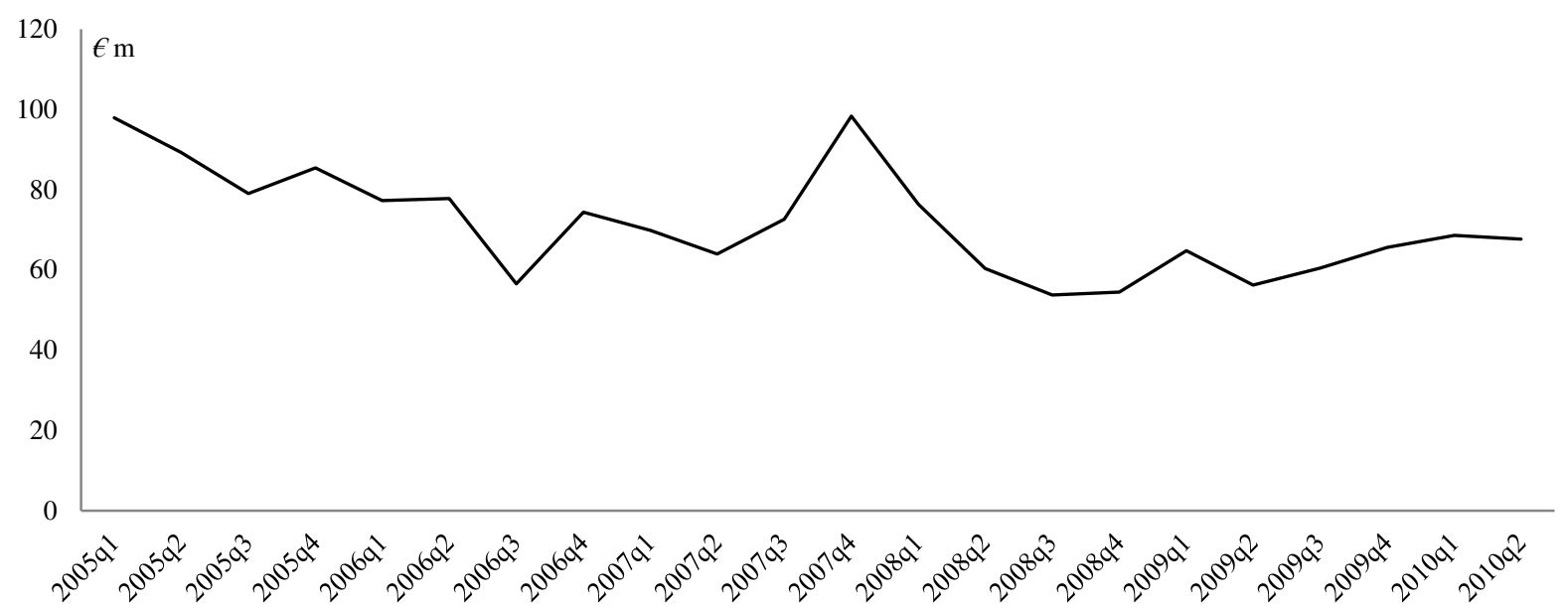




\section{Figure 2}

Deposit Rate and EURIBOR

The figure shows the average deposit rate on the platform using all bank bids together with the 1-week EURIBOR on a daily basis from January 2005 to June 2010 .

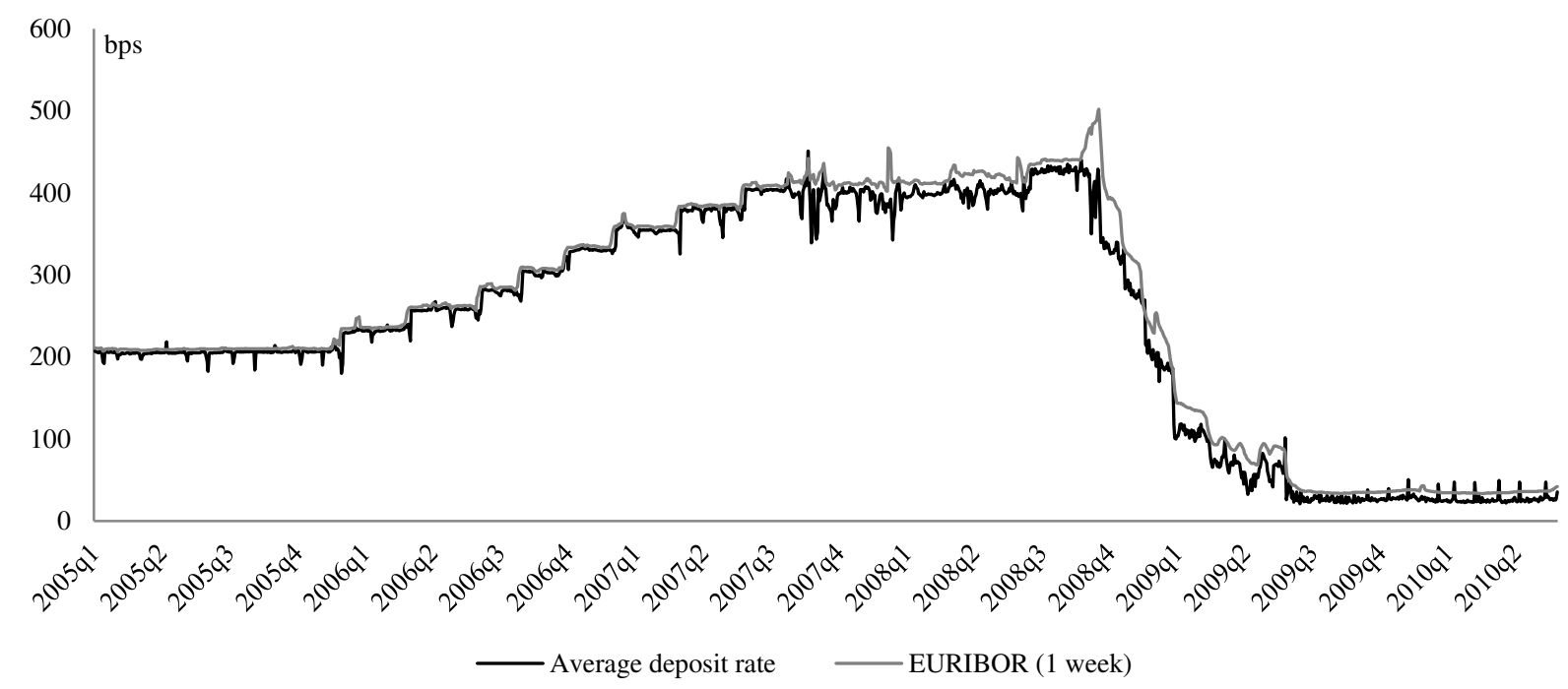




\section{Figure 3}

\section{Interest Income Differences and Bid Selection}

The figure shows the average difference in interest income of the highest to lower bids and the frequency of bids selected according to their rank in an auction by their interest rate using all auctions where a bid is selected from January 2005 to June 2010. Figure 3A displays the difference in interest income between the highest and the lowest bid in an auction. Figure 3B depicts the percentage of firms selecting the highest, second highest, third highest, fourth highest and fifth highest or lower bid in a transaction.

\section{Panel A: Interest income difference between highest and lowest bid in an auction (in $€$ )}

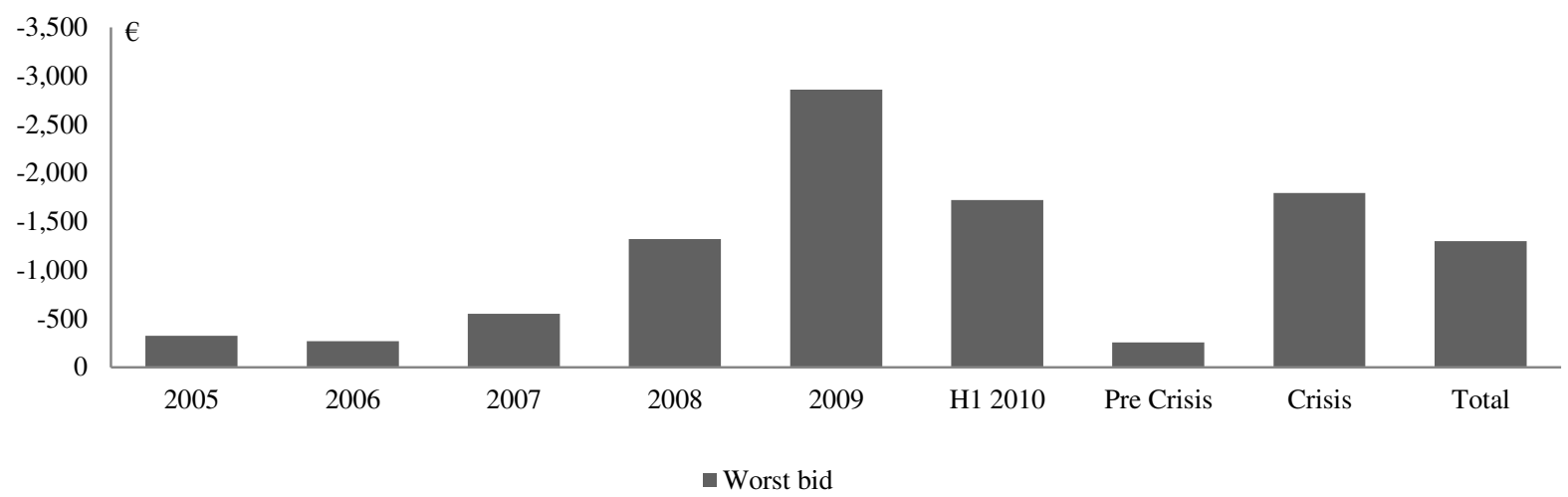

Panel B: Percentage of x-th highest bid selected by firm (\%)

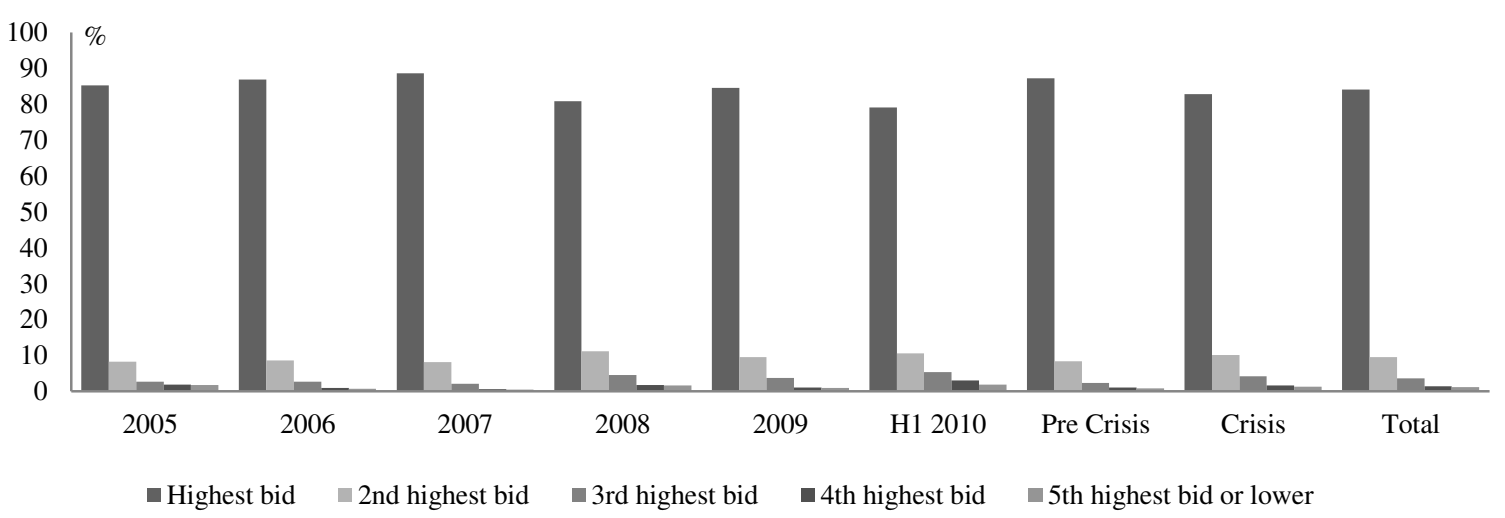




\section{Figure 4}

\section{Number of Bidding Banks and Interest Rate by Frequency of Firm Deposit Offers}

The figure shows statistics for the number of bidding banks (Fig. 4A) and the difference in deposit bid interest rate in bps (Fig. 4B) by the frequency of firms offering deposits on the trading platform. Firms that offer deposits frequently and those that offer deposits less frequently are determined via a threshold using the median number of deposit offers on the firm-level in each quarter. The first graph in Figure 4A (4B) shows the t-statistic of the difference between the number of bidding banks (difference in deposit bid interest rate) between both firm groups. The second graph in Figure 4A (4B) displays the $2.5^{\text {th }}$ and $97.5^{\text {th }}$ percentile of the difference of number of bidding banks (difference in deposit bid interest rate) between both firm groups.

\section{Panel A: Difference in number of bidding banks per auction}
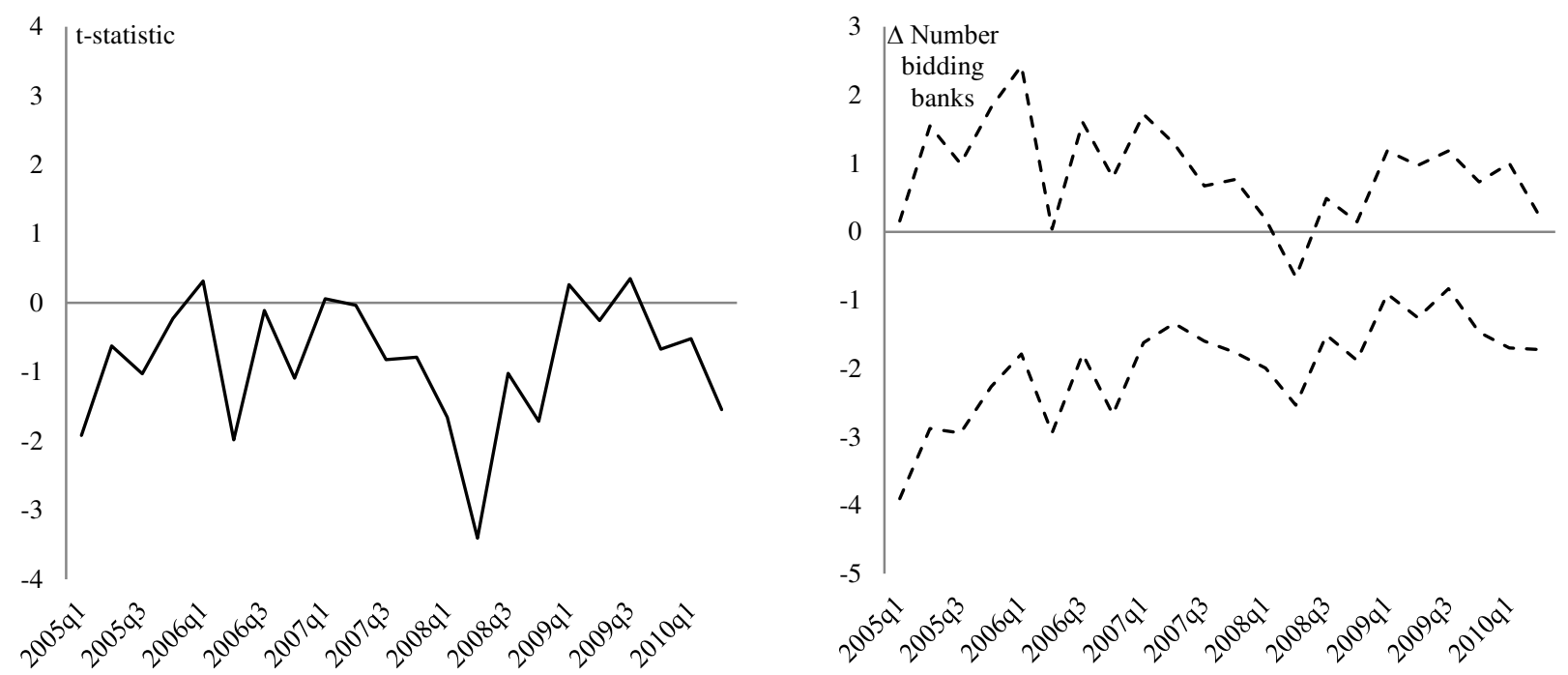

\section{Panel B: Difference in interest rate bid per auction}
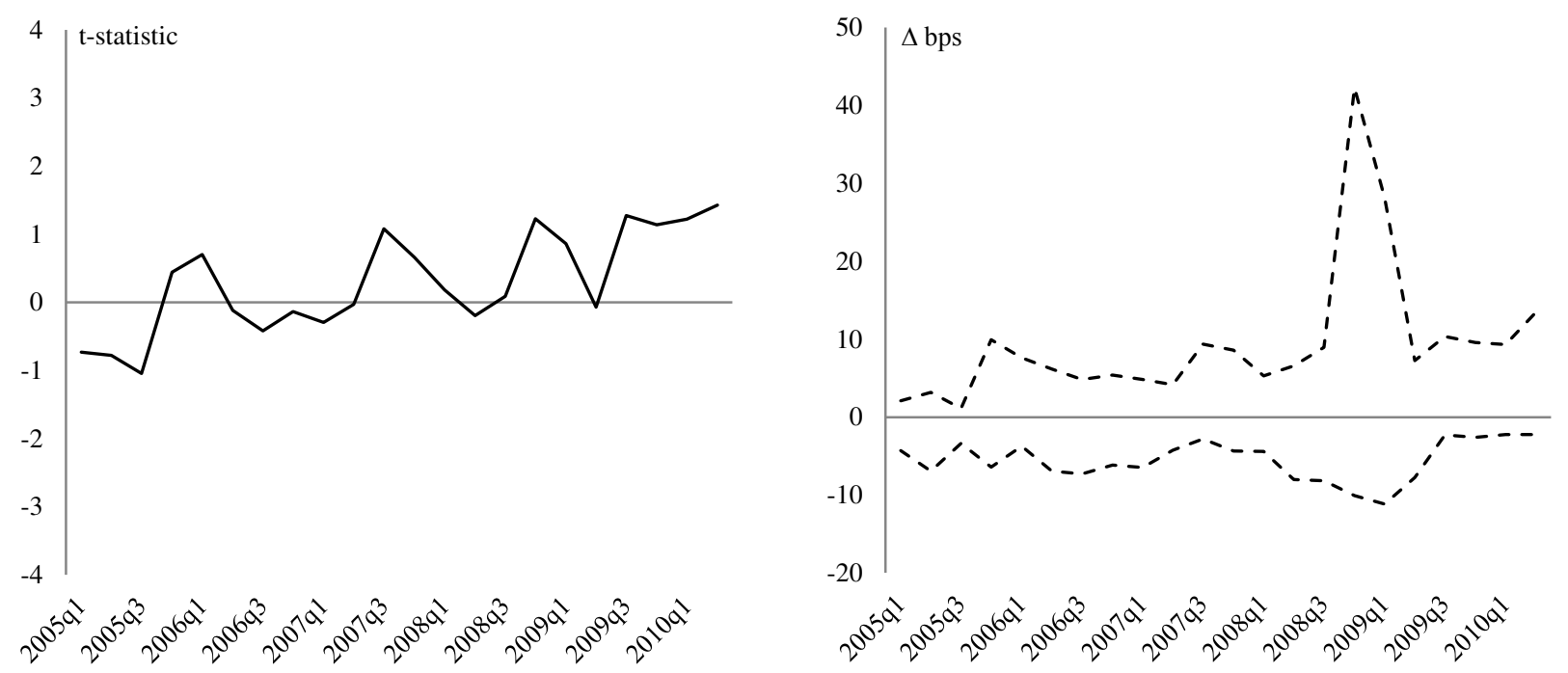


\section{Figure 5}

\section{Bank-Firm Relationship by Bank Risk and Deposit Amount}

The figure shows the relationship (trades) measure from January 2005 to June 2010. Figure 5A subdivides banks into high risk and low risk banks using the median value of bank risk determined via bank CDS spreads in each quarter as threshold. It shows the $25^{\text {th }}$ and the $75^{\text {th }}$ percentile of the relationship (trades) measure for these bank risk groups. Figure 5B subdivides the sample into small and large notional deposit amounts using the median value of notional deposit amounts in an auction in each quarter as threshold. It shows the $25^{\text {th }}$ and the $75^{\text {th }}$ percentile of the relationship (trades) measure for these size groups.

\section{Panel A: $25^{\text {th }}$ and $75^{\text {th }}$ percentile of relationship (trades) for high- and low-risk banks}

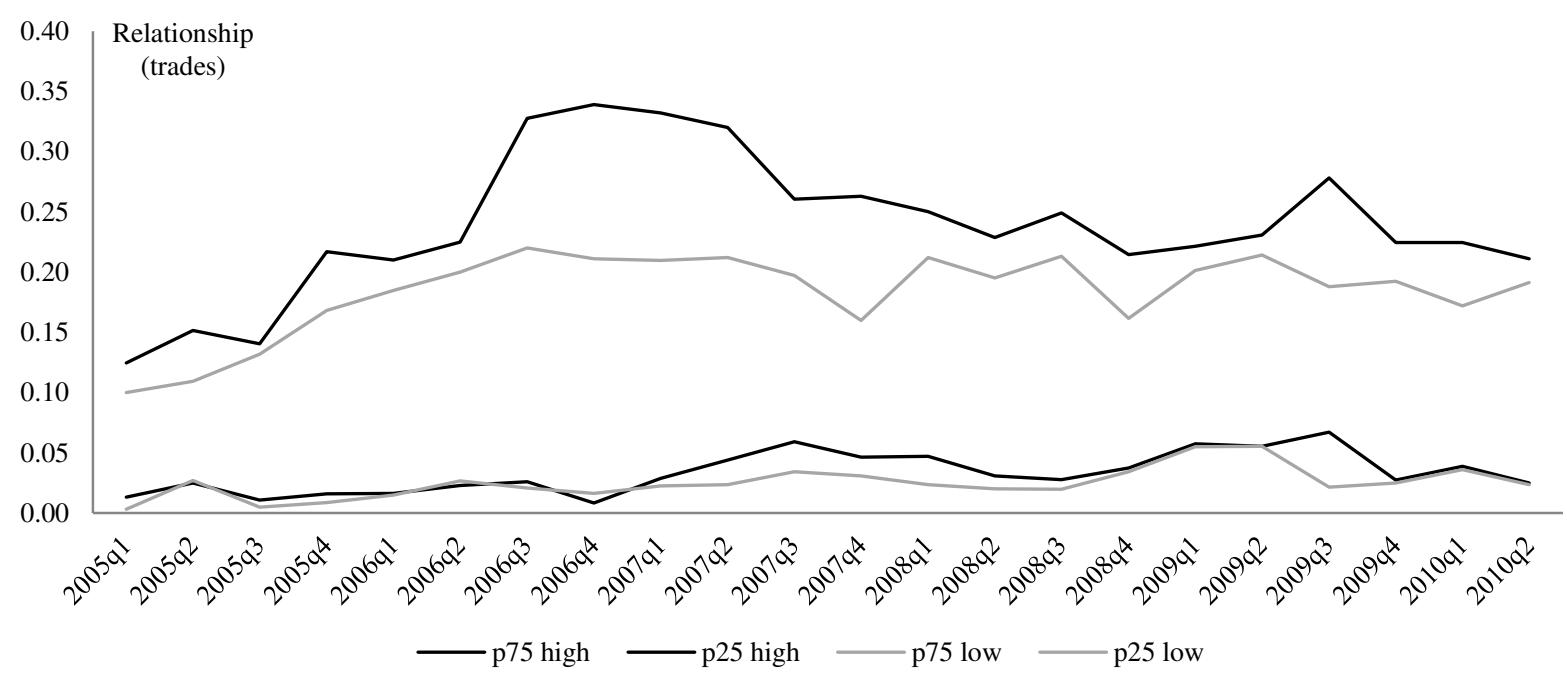

Panel B: $25^{\text {th }}$ and $75^{\text {th }}$ percentile of relationship (trades) for small and large amounts

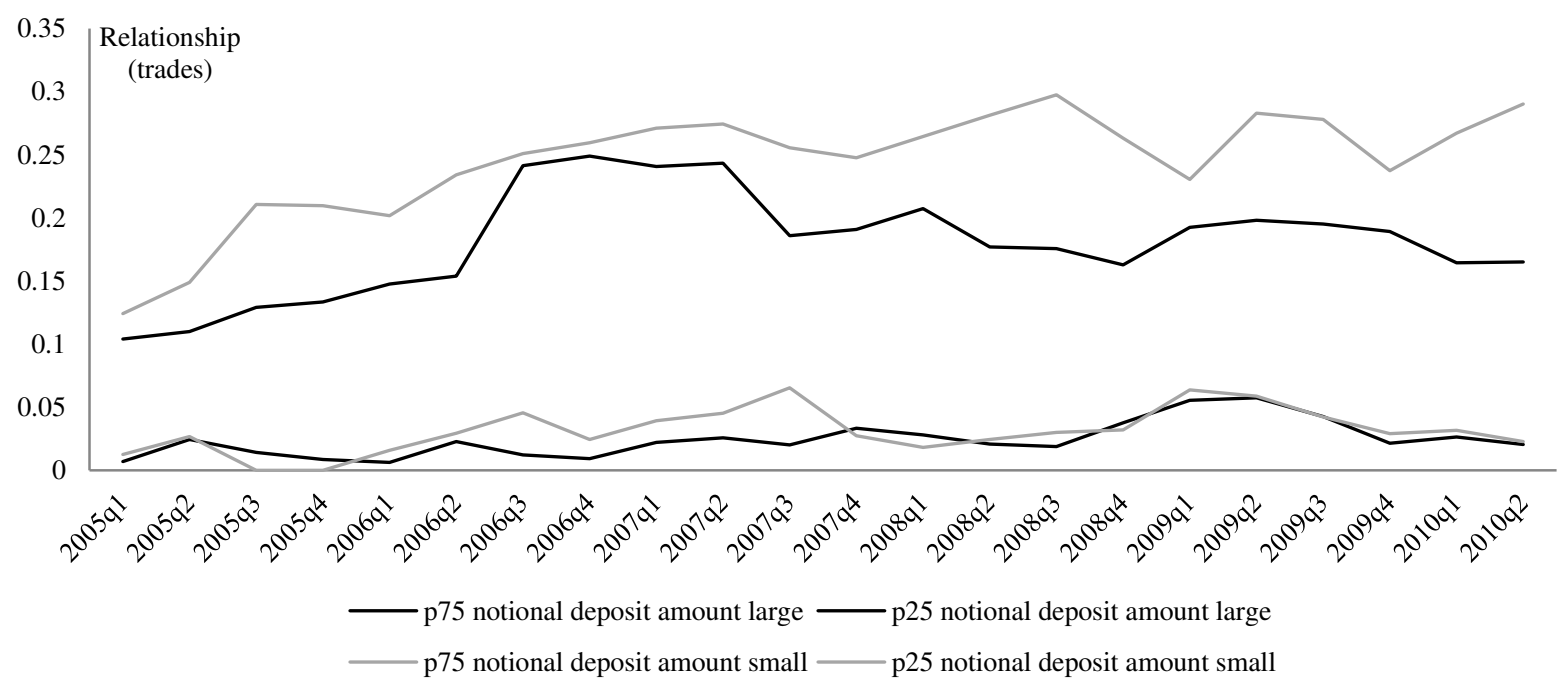




\section{Table 1}

\section{Descriptive Statistics}

The table shows descriptive statistics of data from January 2005 to June 2010. Panel A reports deposit transaction variables and Panel B bank characteristics. All variables in Panel B except Bank CDS spreads are measured in real terms with 2005 as base year using the Consumer Price Index (CPI) as published by the OECD. All variables are defined in Appendix A1.

\section{Panel A: Transaction variables}

\begin{tabular}{|c|c|c|c|c|c|c|c|}
\hline & 2005 & 2006 & 2007 & 2008 & 2009 & 2010:H1 & Total Period \\
\hline \multicolumn{8}{|l|}{ Firm-related transaction variables } \\
\hline Number of firms offering deposits & 40 & 55 & 81 & 115 & 109 & 91 & 192 \\
\hline Number of auctions per quarter & 1,472 & 1,981 & 3,424 & 4,779 & 4,738 & 4,835 & 3,420 \\
\hline$\%$ of auctions with transaction & $67.0 \%$ & $68.6 \%$ & $68.2 \%$ & $62.9 \%$ & $63.1 \%$ & $63.7 \%$ & $64.9 \%$ \\
\hline$\%$ of auctions with transaction, not highest bid selected & $14.7 \%$ & $13.1 \%$ & $11.4 \%$ & $19.2 \%$ & $15.4 \%$ & $20.9 \%$ & $15.9 \%$ \\
\hline Number of auctions per firm-quarter & 53 & 54 & 63 & 62 & 63 & 64 & 61 \\
\hline Number of auctions with transaction per firm-quarter & 41 & 42 & 46 & 45 & 47 & 47 & 45 \\
\hline Notional amount per auction $(€ m)$ & 87 & 71 & 79 & 61 & 62 & 68 & 69 \\
\hline Notional amount per auction with transaction $(€ m)$ & 98 & 75 & 83 & 63 & 71 & 69 & 74 \\
\hline Maturity per auction (days) & 5.2 & 4.7 & 4.5 & 7.1 & 11.6 & 11.4 & 7.9 \\
\hline Maturity per auction with transaction (days) & 4.8 & 3.9 & 3.9 & 5.4 & 8.6 & 8.3 & 6.0 \\
\hline \multicolumn{8}{|l|}{ Bank-related transaction variables } \\
\hline Number of banks bidding for deposits & 35 & 36 & 39 & 45 & 49 & 44 & 61 \\
\hline Number of bids per quarter & 6,920 & 7,621 & 11,018 & 15,714 & 13,070 & 16,619 & 11,391 \\
\hline Number of bids per bank-quarter & 243 & 246 & 336 & 422 & 309 & 391 & 325 \\
\hline Relationship (trades) & 0.121 & 0.146 & 0.174 & 0.160 & 0.161 & 0.147 & 0.155 \\
\hline Relationship (amount) & 0.122 & 0.147 & 0.175 & 0.159 & 0.163 & 0.148 & 0.156 \\
\hline \multicolumn{8}{|l|}{ Further transaction variables } \\
\hline Number of bidding banks per auction & 4.7 & 3.8 & 3.2 & 3.3 & 2.7 & 3.4 & 3.3 \\
\hline Deposit interest rate per auction (bps) & 208 & 285 & 385 & 373 & 57 & 26 & 229 \\
\hline $\begin{array}{l}\text { Difference between lowest and highest bid per auction } \\
\text { (bps) }\end{array}$ & 3 & 2 & 4 & 12 & 10 & 7 & 8 \\
\hline
\end{tabular}

Panel B: Bank characteristics

\begin{tabular}{lc}
\hline & Total Period \\
\hline Total assets (in 2005 $€ m$ ) & 570,547 \\
Leverage & 0.959 \\
Return on equity & 0.070 \\
Asset growth & -0.016 \\
Net interest margin & 0.011 \\
Cost / income ratio & 0.685 \\
Net loans / customer deposits & 0.796 \\
Non-performing loans / total loans & 0.027 \\
Balance-sheet (BS) derivate exposure / total assets & 0.004 \\
Off-balance-sheet (OBS) exposure & 0.188 \\
Bank CDS spread (bps) & 78.280 \\
\hline
\end{tabular}




\section{Table 2}

\section{Selection of Banks by Firms}

The table reports OLS regression results of an indicator variable, which is one when a bid is selected and zero otherwise, on control variables using data from January 2005 to June 2010. The data include all auctions where a bid is selected and at least two banks are bidding. All variables are defined in Appendix A1. Bank risk is used with its value on the day prior to the transaction. The relationship variables are derived over the previous year excluding the current transaction. Bank characteristics are used as stated in the annual report in the year prior to the transaction. The time fixed effects in Panels B to D are based on quarter. The crisis period in Panel C ranges from August 8, 2007 to June 30, 2010. The period 6 months after the default of Lehman Brothers in Panel D ranges from September 15, 2008 to March 15, 2009. The statistical significance of the results is indicated by $*=10 \%$ level, $* *=5 \%$ level and $* * *=1 \%$ level using heteroscedasticity-robust standard errors clustered at the bank-level.

\section{Panel A: Total period}

\begin{tabular}{|c|c|c|c|c|c|c|c|c|c|}
\hline \multirow[t]{2}{*}{ Dependent Variable } & \multicolumn{9}{|c|}{$1=$ Executed bid } \\
\hline & I & II & III & IV & $\mathrm{V}$ & VI & VII & VIII & IX \\
\hline \multicolumn{10}{|l|}{ Bank Risk } \\
\hline Bank risk & & $0.020 * *$ & & & & 0.010 & & 0.010 & \\
\hline Bank risk - within auction & & & 0.014 & & & & 0.001 & & 0.001 \\
\hline \multicolumn{10}{|l|}{ Transaction Variable } \\
\hline Highest bid of auction & $0.450 * * *$ & $0.457 * * *$ & $0.505^{* * *}$ & $0.416^{* * *}$ & $0.417 * * *$ & $0.422 * * *$ & $0.478 * * *$ & $0.423 * * *$ & $0.478 * * *$ \\
\hline \multicolumn{10}{|l|}{ Relationship } \\
\hline Relationship (trades) & & & & $0.514 * * *$ & & $0.508 * * *$ & $0.471 * * *$ & & \\
\hline Relationship (amount) & & & & & $0.486^{* * *}$ & & & $0.479 * * *$ & $0.444 * * *$ \\
\hline \multicolumn{10}{|l|}{ Other Transaction Variables } \\
\hline First bid of auction & 0.003 & -0.002 & $-0.020 *$ & -0.004 & -0.004 & -0.007 & $-0.018 * *$ & -0.007 & $-0.019 * *$ \\
\hline Log (number banks per auction) & $-0.120 * * *$ & $-0.120 * * *$ & $-0.160 * * *$ & $-0.076^{* * *}$ & $-0.080 * * *$ & $-0.078 * * *$ & $-0.104 * * *$ & $-0.081 * * *$ & $-0.108 * * *$ \\
\hline \multicolumn{10}{|l|}{ Bank Accounting Variables } \\
\hline Log (total assets) & $-0.017 *$ & $-0.028 * * *$ & $-0.027 * *$ & -0.000 & -0.002 & -0.006 & -0.005 & -0.008 & -0.006 \\
\hline Leverage & -0.838 & -0.488 & 0.234 & -0.633 & -0.453 & -0.442 & 0.265 & -0.274 & 0.396 \\
\hline Return on equity & -0.034 & 0.010 & -0.035 & -0.046 & $-0.049 *$ & -0.028 & -0.044 & -0.030 & -0.046 \\
\hline Asset growth & 0.048 & $0.154 * *$ & 0.096 & 0.032 & 0.020 & 0.083 & 0.058 & 0.072 & 0.043 \\
\hline Net interest margin & 0.001 & 0.014 & 0.032 & -0.003 & 0.001 & 0.006 & 0.014 & 0.009 & 0.019 \\
\hline Cost / income ratio & 0.004 & 0.010 & 0.005 & -0.007 & -0.011 & -0.004 & -0.002 & -0.008 & -0.002 \\
\hline Net loans / customer deposits & 0.010 & 0.004 & -0.037 & 0.014 & 0.001 & 0.007 & -0.023 & -0.004 & -0.034 \\
\hline Non-performing loans / total loans & 0.590 & $0.883^{*}$ & $1.111^{* *}$ & 0.391 & 0.369 & 0.511 & $0.891 * * *$ & 0.505 & $0.843 * *$ \\
\hline$B S$ derivate exposure / total assets & -0.091 & -0.035 & -0.027 & -0.169 & -0.195 & -0.131 & 0.105 & -0.159 & 0.121 \\
\hline OBS exposure & -0.094 & -0.092 & -0.085 & -0.064 & -0.058 & -0.068 & -0.057 & -0.060 & -0.051 \\
\hline Constant & $1.311 * *$ & 1.028 & 0.423 & 0.764 & 0.634 & 0.620 & -0.020 & 0.497 & -0.112 \\
\hline Observations & 112,750 & 105,078 & 57,829 & 112,213 & 112,213 & 104,577 & 57,552 & 104,577 & 57,552 \\
\hline Adjusted R-squared & 0.305 & 0.317 & 0.357 & 0.341 & 0.340 & 0.354 & 0.390 & 0.352 & 0.387 \\
\hline
\end{tabular}

Panel B: Total period, including fixed effects

\begin{tabular}{|c|c|c|c|c|c|c|c|c|c|}
\hline \multirow[t]{2}{*}{ Dependent Variable } & \multicolumn{9}{|c|}{$1=$ Executed bid } \\
\hline & $\mathrm{I}$ & II & III & IV & V & VI & VII & VIII & IX \\
\hline \multicolumn{10}{|l|}{ Bank Risk } \\
\hline Bank risk & & 0.005 & & & & 0.005 & & 0.004 & \\
\hline Bank risk - within auction & & & -0.001 & & & & -0.002 & & -0.003 \\
\hline \multicolumn{10}{|l|}{ Transaction Variable } \\
\hline Highest bid of auction & $0.430 * * *$ & $0.438^{* * * *}$ & $0.484 * * *$ & $0.412 * * *$ & $0.412 * * *$ & $0.419 * * *$ & $0.468 * * *$ & $0.420 * * *$ & $0.469 * * *$ \\
\hline \multicolumn{10}{|l|}{ Relationship } \\
\hline Relationship (trades) & & & & $0.585 * * *$ & & $0.594 * * *$ & $0.594 * * *$ & & \\
\hline Relationship (amount) & & & & & $0.530 * * *$ & & & $0.541 * * *$ & $0.548 * * *$ \\
\hline Other Transaction Variables & Yes & Yes & Yes & Yes & Yes & Yes & Yes & Yes & Yes \\
\hline Bank-Firm Fixed Effects & Yes & Yes & Yes & Yes & Yes & Yes & Yes & Yes & Yes \\
\hline Bank-Time Fixed Effects & Yes & Yes & Yes & Yes & Yes & Yes & Yes & Yes & Yes \\
\hline Observations & 145,434 & 127,992 & 70,051 & 144,744 & 144,744 & 127,394 & 69,721 & 127,394 & 69,721 \\
\hline Adjusted R-squared & 0.325 & 0.331 & 0.361 & 0.358 & 0.355 & 0.365 & 0.397 & 0.362 & 0.393 \\
\hline
\end{tabular}


Panel C: Crisis period, including fixed effects

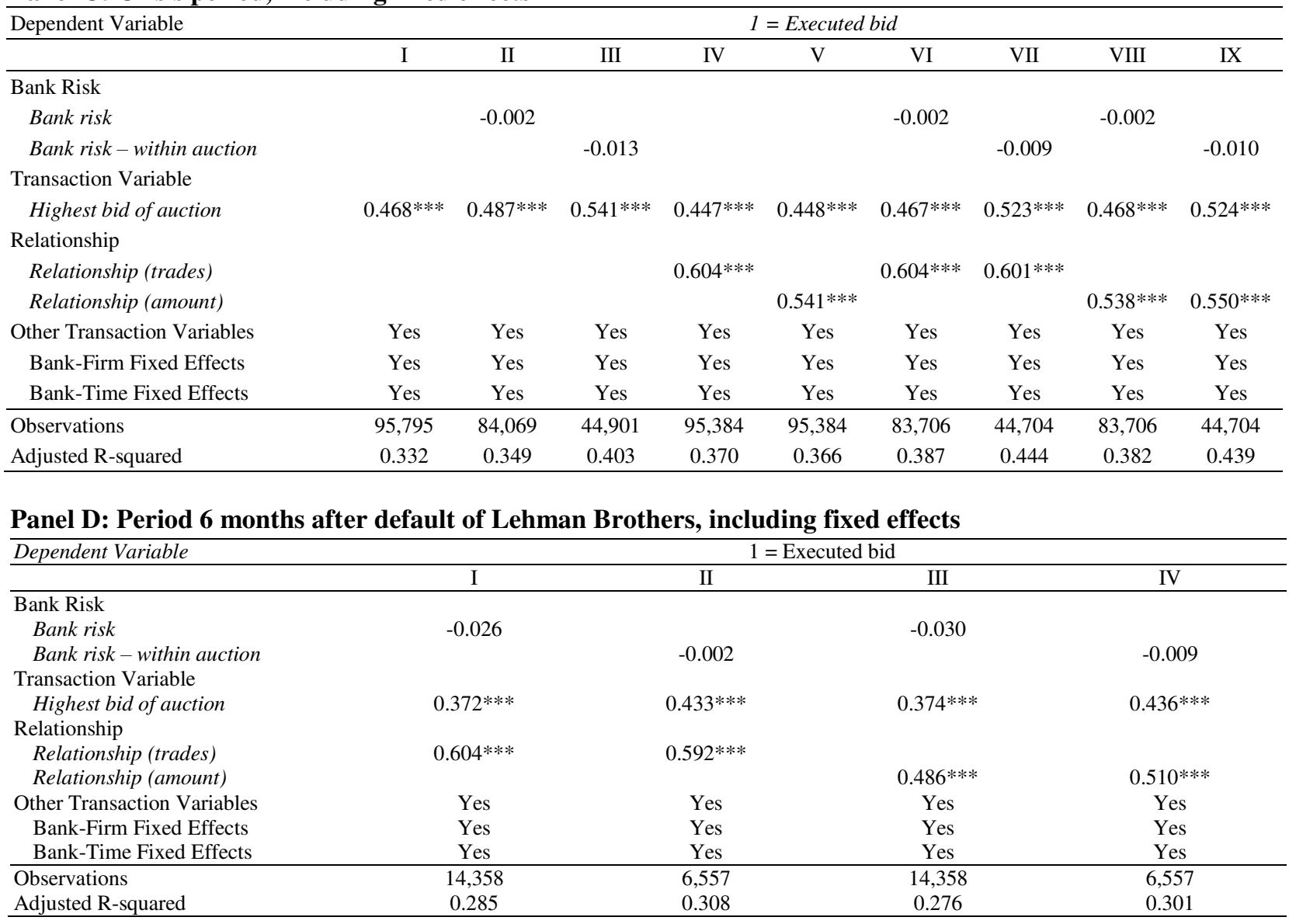




\section{Table 3}

\section{Selection of Banks by Firms - Relationship and Bank Risk}

The table reports OLS regression results of an indicator variable, which is one when a bid is selected and zero otherwise, on control variables using data from January 2005 to June 2010. The data include all auctions where a bid is selected and at least two banks are bidding. A constant is included but omitted. All variables are defined in Appendix A1. Bank risk is used with its value on the day prior to the transaction. The relationship variables are derived over the previous year excluding the current transaction. The time fixed effects are based on quarter. The crisis period in Columns V to VIII ranges from August 8, 2007 to June 30, 2010. The statistical significance of the results is indicated by $*=10 \%$ level, $* *=5 \%$ level and $* * *=1 \%$ level using heteroscedasticity-robust standard errors clustered at the bank-level.

\begin{tabular}{|c|c|c|c|c|c|c|c|c|}
\hline \multirow[t]{3}{*}{ Dependent Variable } & \multicolumn{8}{|c|}{$1=$ Executed bid } \\
\hline & \multicolumn{4}{|c|}{ Total Period } & \multicolumn{4}{|c|}{ Crisis Period } \\
\hline & $\mathrm{I}$ & II & III & IV & $\mathrm{V}$ & VI & VII & VIII \\
\hline \multicolumn{9}{|l|}{$\overline{\text { Bank Risk }}$} \\
\hline Bank risk & 0.002 & & 0.002 & & -0.005 & & -0.002 & \\
\hline Bank risk - within auction & & 0.005 & & 0.005 & & -0.008 & & -0.008 \\
\hline \multicolumn{9}{|l|}{ Transaction Variable } \\
\hline Highest bid of auction & $0.419 * * *$ & $0.469 * * *$ & $0.420 * * *$ & $0.469 * * *$ & $0.467 * * *$ & $0.523 * * *$ & $0.468 * * *$ & $0.524 * * *$ \\
\hline \multicolumn{9}{|l|}{ Relationship } \\
\hline Relationship (trades) & $0.479 * * *$ & $0.676^{* * *}$ & & & $0.524 * * *$ & $0.611 * * *$ & & \\
\hline Relationship (amount) & & & $0.485 * * *$ & $0.647 * * *$ & & & $0.538 * * *$ & $0.578 * * *$ \\
\hline \multicolumn{9}{|c|}{ Relationship-Bank Risk Interaction } \\
\hline $\begin{array}{l}\text { Relationship (trades) * } \\
\text { bank risk }\end{array}$ & 0.028 & & & & 0.018 & & & \\
\hline $\begin{array}{l}\text { Relationship }(\text { trades }) * \\
\text { bank risk - within auction }\end{array}$ & & -0.048 & & & & -0.006 & & \\
\hline $\begin{array}{l}\text { Relationship (amount) * } \\
\text { bank risk }\end{array}$ & & & 0.014 & & & & -0.000 & \\
\hline $\begin{array}{l}\text { Relationship (amount) } * \\
\text { bank risk-within auction }\end{array}$ & & & & -0.057 & & & & -0.017 \\
\hline Other Transaction Variables & Yes & Yes & Yes & Yes & Yes & Yes & Yes & Yes \\
\hline Bank-Firm Fixed Effects & Yes & Yes & Yes & Yes & Yes & Yes & Yes & Yes \\
\hline Bank-Time Fixed Effects & Yes & Yes & Yes & Yes & Yes & Yes & Yes & Yes \\
\hline Observations & 127,394 & 69,721 & 127,394 & 69,721 & 83,706 & 44,704 & 83,706 & 44,704 \\
\hline Adjusted R-squared & 0.365 & 0.397 & 0.362 & 0.393 & 0.387 & 0.444 & 0.382 & 0.439 \\
\hline
\end{tabular}




\section{Table 4}

Selection of Banks by Firms - Alternative Bank Risk Measures

The table reports OLS regression results of an indicator variable, which is one when a bid is selected and zero otherwise, on control variables using data from January 2005 to June 2010. The data include all auctions where a bid is selected and at least two banks are bidding. A constant is included but omitted. All variables are defined in Appendix A1. Bank risk is used with its value on the day prior to the transaction. The relationship variables are derived over the previous year excluding the current transaction. The time fixed effects are based on quarter. Bank risk (rating) is determined using Moody's long-term issuer ratings. Bank risk - within auction (rating) is calculated following the notion of Appendix A3 using these ratings. Non-performing loans are calculated as a fraction of the bank's gross loans. Leverage is calculated as a bank's total liabilities over total assets. The $z$-score is calculated as the natural logarithm of the sum of the return on assets and the ratio of total equity to total assets divided by the standard deviation of the return on assets. We use the previous 10 years for the latter's derivation in each year. The statistica significance of the results is indicated by $*=10 \%$ level, $* *=5 \%$ level and $* * *=1 \%$ level using heteroscedasticity-robust standard errors clustered at the bank-level.

\begin{tabular}{|c|c|c|c|c|c|c|c|c|c|c|c|c|c|c|c|}
\hline \multirow[t]{2}{*}{ Dependent Variable } & \multicolumn{15}{|c|}{$1=$ Executed bid } \\
\hline & I & II & III & IV & $\mathrm{V}$ & VI & VII & VIII & IX & $\mathrm{X}$ & XI & XII & XIII & XIV & $\mathrm{XV}$ \\
\hline \multicolumn{16}{|l|}{ Bank Risk } \\
\hline Bank risk (rating) & $-3.6 \mathrm{E}-3$ & $5.4 \mathrm{E}-4$ & $-3.7 \mathrm{E}-4$ & & & & & & & & & & & & \\
\hline Bank risk - within auction (rating) & & & & $-4.2 \mathrm{E}-3$ & $-1.4 \mathrm{E}-3$ & $-3.6 \mathrm{E}-4$ & & & & & & & & & \\
\hline Non-performing loans / total loans & & & & & & & 0.847 & $0.834 * *$ & $0.940 * *$ & & & & & & \\
\hline Leverage & & & & & & & & & & -0.509 & -0.400 & -0.319 & & & \\
\hline $\log (z$-score $)$ & & & & & & & & & & & & & -0.004 & -0.003 & -0.003 \\
\hline \multicolumn{16}{|l|}{ Transaction Variable } \\
\hline Highest bid of auction & $0.439 * * *$ & $0.409 * * *$ & $0.412^{* * *}$ & $0.468 * * *$ & $0.437 * * *$ & $0.439 * * *$ & $0.441 * * *$ & $0.416^{* * * *}$ & $0.417 * * *$ & $0.434 * * *$ & $0.406^{* * *}$ & $0.408^{* * *}$ & $0.433^{* * *}$ & $0.409 * * *$ & $0.412 * * *$ \\
\hline \multicolumn{16}{|l|}{ Relationship } \\
\hline Relationship (trades) & & $0.579 * * *$ & & & $0.560 * * *$ & & & $0.590 * * *$ & & & $0.584 * * *$ & & & $0.579 * * *$ & \\
\hline Relationship (amount) & & & $0.529 * * *$ & & & $0.515^{* * *}$ & & & $0.538 * * *$ & & & $0.535^{* * *}$ & & & $0.516^{* * *}$ \\
\hline Other Transaction Variables & Yes & Yes & Yes & Yes & Yes & Yes & Yes & Yes & Yes & Yes & Yes & Yes & Yes & Yes & Yes \\
\hline Bank-Firm Fixed Effects & Yes & Yes & Yes & Yes & Yes & Yes & Yes & Yes & Yes & Yes & Yes & Yes & Yes & Yes & Yes \\
\hline Time Fixed Effects & Yes & Yes & Yes & Yes & Yes & Yes & Yes & Yes & Yes & Yes & Yes & Yes & Yes & Yes & Yes \\
\hline Observations & 136,295 & 135,651 & 135,651 & 105,371 & 104,887 & 104,887 & 128,613 & 127,991 & 127,991 & 145,232 & 144,542 & 144,542 & 99,550 & 99,113 & 99,113 \\
\hline Adjusted R-squared & 0.322 & 0.358 & 0.355 & 0.335 & 0.368 & 0.366 & 0.321 & 0.358 & 0.354 & 0.319 & 0.356 & 0.353 & 0.325 & 0.356 & 0.352 \\
\hline
\end{tabular}




\section{Table 5}

\section{Selection of Banks by Firms - GIIPS banks}

The table reports OLS regression results of an indicator variable, which is one when a bid is selected and zero otherwise, on control variables using data from January 2005 to June 2010. The data include all auctions where a bid is selected and at least two banks are bidding. A constant is included but omitted. All variables are defined in Appendix A1. Bank risk is used with its value on the day prior to the transaction. The relationship variables are derived over the previous year excluding the current transaction. The time fixed effects are based on quarter. GIIPS bank is a dummy variable which is one when the bank is headquartered in Greece, Ireland, Italy, Portugal, or Spain, and zero otherwise. The crisis period in Panel B ranges from August 8, 2007 to June 30, 2010. The statistical significance of the results is indicated by $*=10 \%$ level, $* *=5 \%$ level and $* * *=1 \%$ level using heteroscedasticityrobust standard errors clustered at the bank-level.

\section{Panel A: Total period}

\begin{tabular}{|c|c|c|c|c|}
\hline \multirow[t]{2}{*}{ Dependent Variable } & \multicolumn{4}{|c|}{$1=$ Executed bid } \\
\hline & I & II & III & IV \\
\hline \multicolumn{5}{|l|}{ Bank Risk } \\
\hline Bank risk & -0.002 & & -0.002 & \\
\hline Bank risk - within auction & & -0.002 & & -0.002 \\
\hline \multicolumn{5}{|l|}{ Transaction Variable } \\
\hline Highest bid of auction & $0.424 * * *$ & $0.477 * * *$ & $0.425 * * *$ & $0.477 * * *$ \\
\hline \multicolumn{5}{|l|}{ Relationship } \\
\hline Relationship (trades) & $0.572 * * *$ & $0.561 * * *$ & & \\
\hline Relationship (amount) & & & $0.532 * * *$ & $0.524 * * *$ \\
\hline \multicolumn{5}{|l|}{ Bank Headquarter } \\
\hline GIIPS bank & 0.069 & $0.153 * *$ & 0.091 & $0.149 *$ \\
\hline \multicolumn{5}{|l|}{ Bank Risk - Bank Headquarter Interaction } \\
\hline Bank risk * GIIPS bank & -0.008 & & -0.013 & \\
\hline Bank risk - within auction * GIIPS bank & & -0.071 & & -0.072 \\
\hline \multicolumn{5}{|l|}{ Highest Bid - Bank Headquarter Interaction } \\
\hline Highest bid of auction * GIIPS bank & 0.054 & 0.018 & 0.048 & 0.015 \\
\hline Bank Accounting Variables & Yes & Yes & Yes & Yes \\
\hline Other Transaction Variables & Yes & Yes & Yes & Yes \\
\hline Firm Fixed Effects & Yes & Yes & Yes & Yes \\
\hline Time Fixed Effects & Yes & Yes & Yes & Yes \\
\hline Observations & 104,577 & 57,552 & 104,577 & 57,552 \\
\hline Adjusted R-squared & 0.364 & 0.401 & 0.361 & 0.397 \\
\hline
\end{tabular}

Panel B: Crisis period

\begin{tabular}{|c|c|c|c|c|}
\hline \multirow[t]{2}{*}{ Dependent Variable } & \multicolumn{4}{|c|}{$1=$ Executed bid } \\
\hline & I & II & III & IV \\
\hline \multicolumn{5}{|l|}{$\overline{\text { Bank Risk }}$} \\
\hline Bank risk & -0.005 & & -0.004 & \\
\hline Bank risk - within auction & & -0.006 & & -0.003 \\
\hline \multicolumn{5}{|l|}{ Transaction Variable } \\
\hline Highest bid of auction & $0.459 * * *$ & $0.522 * * *$ & $0.460 * * *$ & $0.523 * * *$ \\
\hline \multicolumn{5}{|l|}{ Relationship } \\
\hline Relationship (trades) & $0.551 * * *$ & $0.546^{* * *} *$ & & \\
\hline Relationship (amount) & & & $0.507 * * *$ & $0.508 * * *$ \\
\hline \multicolumn{5}{|l|}{ Bank Headquarter } \\
\hline GIIPS bank & 0.029 & $0.162 * *$ & 0.057 & $0.162 *$ \\
\hline \multicolumn{5}{|l|}{ Bank Risk - Bank Headquarter Interaction } \\
\hline Bank risk * GIIPS bank & -0.000 & & -0.006 & \\
\hline Bank risk - within auction * GIIPS bank & & -0.073 & & -0.075 \\
\hline \multicolumn{5}{|l|}{ Highest Bid - Bank Headquarter Interaction } \\
\hline Highest bid of auction * GIIPS bank & 0.028 & -0.016 & 0.020 & -0.022 \\
\hline Bank Accounting Variables & Yes & Yes & Yes & Yes \\
\hline Other Transaction Variables & Yes & Yes & Yes & Yes \\
\hline Firm FE & Yes & Yes & Yes & Yes \\
\hline Time FE & Yes & Yes & Yes & Yes \\
\hline Observations & 77,649 & 41,693 & 77,649 & 41,693 \\
\hline Adjusted R-squared & 0.379 & 0.439 & 0.375 & 0.434 \\
\hline
\end{tabular}




\section{Table 6}

Selection of Banks by Firms - Intensive Margin

The table reports descriptive statistics in Panel A and in Panel B OLS regression results of an indicator variable, which is one when a bid is selected and zero otherwise, on control variables using data from January 2005 to June 2010. Panel A shows the number of banks and the number of auctions in which these banks are bidding. A bank is defined to be on the intensive margin when it assumes deposits via the trading platform in the period prior to as well as in the financial crisis. The pre-crisis period ranges from January 3, 2005 to Aug. 7, 2007, the crisis period ranges from August 8, 2007 to June 30, 2010. The data in Panel B include all auctions where a bid is selected and at least two banks are bidding. A constant is included but omitted. All variables are defined in Appendix A1. Bank risk is used with its value on the day prior to the transaction. The relationship variables are derived over the previous year excluding the current transaction. The time fixed effects are based on quarter. The statistical significance of the results is indicated by $*=10 \%$ level, $* *=5 \%$ level and $* * *=1 \%$ level using heteroscedasticity-robust standard errors clustered at the bank-level.

Panel A: Descriptive statistics

\begin{tabular}{lccc}
\hline & Total Period & Pre-Crisis Period & Crisis Period \\
\hline Intensive Margin & & 37 & 37 \\
$\quad$ Number of banks & 37 & 76,424 & 166,031 \\
$\quad$ Number of observations & 242,455 & & 17 \\
Extensive Margin & 24 & 1,819 & 6,333 \\
$\quad$ Number of banks & 8,152 & Number of observations &
\end{tabular}

Panel B: Intensive margin

\begin{tabular}{|c|c|c|c|c|c|c|c|c|c|}
\hline \multirow[t]{2}{*}{ Dependent Variable } & \multicolumn{9}{|c|}{$1=$ Executed bid } \\
\hline & $\mathrm{I}$ & II & III & IV & $\mathrm{V}$ & VI & VII & VIII & IX \\
\hline \multicolumn{10}{|l|}{ Bank Risk } \\
\hline Bank risk & & 0.005 & & & & 0.005 & & 0.004 & \\
\hline Bank risk - within auction & & & -0.001 & & & & -0.002 & & -0.003 \\
\hline \multicolumn{10}{|l|}{ Transaction Variable } \\
\hline Highest bid of auction & $0.420 * * *$ & $0.428 * * *$ & $0.472 * * *$ & $0.403 * * *$ & $0.403 * * *$ & $0.410^{* * *}$ & $0.456^{* * *}$ & $0.410 * * *$ & $0.457 * * *$ \\
\hline \multicolumn{10}{|l|}{ Relationship } \\
\hline Relationship (trades) & & & & $0.588 * * *$ & & $0.597 * * *$ & $0.597 * * *$ & & \\
\hline Relationship (amount) & & & & & $0.532 * * *$ & & & $0.542 * * *$ & $0.551 * * *$ \\
\hline Other Transaction Variables & Yes & Yes & Yes & Yes & Yes & Yes & Yes & Yes & Yes \\
\hline Bank-Firm Fixed Effects & Yes & Yes & Yes & Yes & Yes & Yes & Yes & Yes & Yes \\
\hline Bank-Time Fixed Effects & Yes & Yes & Yes & Yes & Yes & Yes & Yes & Yes & Yes \\
\hline Observations & 140,837 & 124,635 & 68,524 & 140,169 & 140,169 & 124,049 & 68,204 & 124,049 & 68,204 \\
\hline Adjusted R-squared & 0.318 & 0.324 & 0.351 & 0.352 & 0.349 & 0.359 & 0.388 & 0.355 & 0.384 \\
\hline
\end{tabular}




\section{Table 7}

Selection of Banks by Firms when Bank Risk Increases Substantially

The table reports OLS regression results of an indicator variable, which is one when a bid is selected and zero otherwise, on control variables using data from January 2005 to June 2010. The data include all auctions where a bid is selected and at least two banks are bidding. A constant is included but omitted. All variables are defined in Appendix A1. Bank risk is used with its value on the day prior to the transaction. The relationship variables are derived over the previous year excluding the current transaction. The time fixed effects are based on quarter. Change $>5 \%$ above median is a dummy variable which is one when the percentage change of a bank's CDS spread is more than 5 percentage points above the median percentage change of CDS spreads of all sample banks over the same time interval. Increase $>x \%$ is a dummy variable which is one when a bank's CDS spread increases more than $\mathrm{x} \%$ over the specified time interval. In the regressions, these variables are used with their value in the previous period. The crisis period ranges from August 8, 2007 to June $30,2010$. The statistical significance of the results is indicated by $*=10 \%$ level, $* *=5 \%$ level and $* * *=1 \%$ level using heteroscedasticity-robust standard errors clustered at the banklevel.

\begin{tabular}{|c|c|c|c|c|c|c|c|c|c|c|c|c|}
\hline \multirow[t]{3}{*}{ Dependent Variable } & \multicolumn{12}{|c|}{$1=$ Executed bid } \\
\hline & \multicolumn{6}{|c|}{ Total Period } & \multicolumn{6}{|c|}{ Crisis Period } \\
\hline & I & II & III & IV & $\mathrm{V}$ & VI & VII & VIII & IX & $\mathrm{X}$ & XI & XII \\
\hline \multicolumn{13}{|l|}{ Change in bank risk - Week } \\
\hline Change $>5 \%$ above median & 0.003 & & & & & & 0.005 & & & & & \\
\hline Increase $>20 \%$ & & -0.009 & & & & & & -0.006 & & & & \\
\hline Increase $>70 \%$ & & & -0.013 & & & & & & -0.017 & & & \\
\hline \multicolumn{13}{|l|}{ Change in bank risk - Quarter } \\
\hline Change $>5 \%$ above median & & & & 0.005 & & & & & & 0.005 & & \\
\hline Increase $>20 \%$ & & & & & 0.002 & & & & & & 0.003 & \\
\hline Increase $>70 \%$ & & & & & & 0.006 & & & & & & 0.006 \\
\hline \multicolumn{13}{|l|}{ Bank Risk } \\
\hline Bank risk & 0.005 & 0.006 & 0.005 & 0.004 & 0.004 & 0.004 & -0.002 & -0.002 & -0.002 & -0.003 & -0.003 & -0.004 \\
\hline \multicolumn{13}{|l|}{ Transaction Variable } \\
\hline Highest bid of auction & $0.420^{* * * *}$ & $0.420 * * *$ & $0.420 * * *$ & $0.423 * * *$ & $0.423 * * *$ & $0.423 * * *$ & $0.466 * * *$ & $0.466 * * *$ & $0.466 * * *$ & $0.466 * * *$ & $0.466 * * *$ & $0.466^{* * * *}$ \\
\hline \multicolumn{13}{|l|}{ Relationship } \\
\hline Relationship (trades) & $0.595 * * *$ & $0.595 * * *$ & $0.595 * * *$ & $0.600 * * *$ & $0.600 * * *$ & $0.600 * * *$ & $0.604 * * *$ & $0.604 * * *$ & $0.604 * * *$ & $0.604 * * *$ & $0.604 * * *$ & $0.604 * * * *$ \\
\hline Other Transaction Variables & Yes & Yes & Yes & Yes & Yes & Yes & Yes & Yes & Yes & Yes & Yes & Yes \\
\hline Bank-Firm Fixed Effects & Yes & Yes & Yes & Yes & Yes & Yes & Yes & Yes & Yes & Yes & Yes & Yes \\
\hline Bank-Time Fixed Effects & Yes & Yes & Yes & Yes & Yes & Yes & Yes & Yes & Yes & Yes & Yes & Yes \\
\hline Observations & 125,916 & 125,916 & 125,916 & 121,192 & 121,192 & 121,192 & 83,183 & 83,183 & 83,183 & 82,333 & 82,333 & 82,333 \\
\hline Adjusted R-squared & 0.366 & 0.366 & 0.366 & 0.367 & 0.367 & 0.367 & 0.387 & 0.387 & 0.387 & 0.386 & 0.386 & 0.386 \\
\hline
\end{tabular}




\section{Table 8}

\section{Selection of Banks by Firms by Deposit Characteristics}

The table reports OLS regression results of an indicator variable, which is one when a bid is selected and zero otherwise, on control variables using data from January 2005 to June 2010. The data include all auctions where a bid is selected and at least two banks are bidding. A constant is included but omitted. All variables are defined in Appendix A1. Bank risk is used with its value on the day prior to the transaction. The relationship variables are derived over the previous year excluding the current transaction. The time fixed effects are based on quarter. In Panel A, Extremely high bid is defined as a dummy variable which is one if the highest bank bid is $50 \%$ above the median interest rate of all bids in this auction. Panel A only includes auctions where a bid is selected and at least three banks are bidding. In Panel B, columns I to IV only include auctions with a maturity of one day and columns V to VIII include only auctions with a maturity of more than five days. In Panel C, columns I to IV only include auctions with a notional amount of up to $€ 100$ million and columns V to VIII include only auctions with a notional amount of more than $€ 100$ million. The statistical significance of the results is indicated by $*=10 \%$ level, $* *=5 \%$ level and $* * *=$ $1 \%$ level using heteroscedasticity-robust standard errors clustered at the bank-level.

Panel A: Extremely high bids

\begin{tabular}{|c|c|c|c|c|c|c|c|c|c|}
\hline \multirow[t]{2}{*}{ Dependent Variable } & \multicolumn{9}{|c|}{$1=$ Executed bid } \\
\hline & $\mathrm{I}$ & II & III & IV & $\mathrm{V}$ & VI & VII & VIII & IX \\
\hline Extremely high bid & 0.029 & 0.021 & $0.144 * * *$ & -0.018 & -0.003 & -0.022 & 0.075 & -0.005 & 0.089 \\
\hline Bank Risk & & & & & & & & & \\
\hline Bank risk & & 0.005 & & & & 0.005 & & 0.004 & \\
\hline Bank risk - within auction & & & -0.003 & & & & -0.004 & & -0.005 \\
\hline Transaction Variable & & & & & & & & & \\
\hline Highest bid of auction & $0.412 * * *$ & $0.421 * * *$ & $0.472 * * *$ & $0.396 * * *$ & $0.396 * * *$ & $0.404 * * *$ & $0.459 * * *$ & $0.404 * * *$ & $0.459 * * *$ \\
\hline Relationship & & & & & & & & & \\
\hline Relationship (trades) & & & & $0.585 * * *$ & & $0.602 * * *$ & $0.601 * * *$ & & \\
\hline Relationship (amount) & & & & & $0.520 * * *$ & & & $0.538 * * *$ & $0.548 * * *$ \\
\hline Other Transaction Variables & Yes & Yes & Yes & Yes & Yes & Yes & Yes & Yes & Yes \\
\hline Bank-Firm Fixed Effects & Yes & Yes & Yes & Yes & Yes & Yes & Yes & Yes & Yes \\
\hline Bank-Time Fixed Effects & Yes & Yes & Yes & Yes & Yes & Yes & Yes & Yes & Yes \\
\hline Observations & 131,342 & 114,792 & 57,730 & 130,784 & 130,784 & 114,310 & 57,502 & 114,310 & 57,502 \\
\hline Adjusted R-squared & 0.290 & 0.295 & 0.332 & 0.320 & 0.317 & 0.327 & 0.365 & 0.323 & 0.361 \\
\hline
\end{tabular}

\section{Panel B: Deposit maturity}

\begin{tabular}{|c|c|c|c|c|c|c|c|c|}
\hline \multirow[t]{3}{*}{ Dependent Variable } & \multicolumn{8}{|c|}{$1=$ Executed bid } \\
\hline & \multicolumn{4}{|c|}{ Overnight } & \multicolumn{4}{|c|}{$>5$ days } \\
\hline & I & II & III & IV & $\mathrm{V}$ & VI & VII & VIII \\
\hline \multicolumn{9}{|l|}{ Bank Risk } \\
\hline Bank risk & 0.003 & & 0.002 & & $0.012 * * *$ & & $0.012 * * *$ & \\
\hline Bank risk - within auction & & -0.001 & & -0.003 & & 0.008 & & 0.008 \\
\hline \multicolumn{9}{|l|}{ Transaction Variable } \\
\hline Highest bid of auction & $0.360 * * *$ & $0.401 * * *$ & $0.359 * * *$ & $0.401 * * *$ & $0.657 * * *$ & $0.699 * * *$ & $0.658 * * *$ & $0.699 * * *$ \\
\hline \multicolumn{9}{|l|}{ Relationship } \\
\hline Relationship (trades) & $0.670 * * *$ & $0.667 * * *$ & & & $0.180 * * *$ & $0.160 * * *$ & & \\
\hline Relationship (amount) & & & $0.615^{* * *} *$ & $0.627 * * *$ & & & $0.161 * * *$ & $0.151 * * *$ \\
\hline Other Transaction Variables & Yes & Yes & Yes & Yes & Yes & Yes & Yes & Yes \\
\hline Bank-Firm Fixed Effects & Yes & Yes & Yes & Yes & Yes & Yes & Yes & Yes \\
\hline Bank-Time Fixed Effects & Yes & Yes & Yes & Yes & Yes & Yes & Yes & Yes \\
\hline Observations & 78,419 & 40,697 & 78,419 & 40,697 & 22,799 & 14,436 & 22,799 & 14,436 \\
\hline Adjusted R-squared & 0.343 & 0.364 & 0.340 & 0.360 & 0.520 & 0.584 & 0.520 & 0.584 \\
\hline
\end{tabular}

Panel C: Deposit notional amount

\begin{tabular}{|c|c|c|c|c|c|c|c|c|}
\hline \multirow[t]{3}{*}{ Dependent Variable } & \multicolumn{8}{|c|}{$1=$ Executed bid } \\
\hline & \multicolumn{4}{|c|}{$\leq € 100$ million } & \multicolumn{4}{|c|}{$>€ 100$ million } \\
\hline & $\mathrm{I}$ & II & III & IV & $\mathrm{V}$ & VI & VII & VIII \\
\hline \multicolumn{9}{|l|}{ Bank Risk } \\
\hline Bank risk & $0.010 * *$ & & $0.009 *$ & & -0.002 & & -0.003 & \\
\hline Bank risk - within auction & & 0.003 & & 0.001 & & -0.011 & & -0.012 \\
\hline \multicolumn{9}{|l|}{ Transaction Variable } \\
\hline Highest bid of auction & $0.400 * * *$ & $0.446 * * *$ & $0.401 * * *$ & $0.446 * * *$ & $0.481 * * *$ & $0.546 * * *$ & $0.479 * * *$ & $0.545 * * *$ \\
\hline \multicolumn{9}{|l|}{ Relationship } \\
\hline Relationship (trades) & $0.625 * * *$ & $0.633 * * *$ & & & $0.395 * * *$ & $0.309 * * *$ & & \\
\hline Relationship (amount) & & & $0.562 * * *$ & $0.585 * * *$ & & & $0.431 * * *$ & $0.322 * * *$ \\
\hline Other Transaction Variables & Yes & Yes & Yes & Yes & Yes & Yes & Yes & Yes \\
\hline Bank-Firm Fixed Effects & Yes & Yes & Yes & Yes & Yes & Yes & Yes & Yes \\
\hline Bank-Time Fixed Effects & Yes & Yes & Yes & Yes & Yes & Yes & Yes & Yes \\
\hline Observations & 93,385 & 55,128 & 93,385 & 55,128 & 34,009 & 14,593 & 34,009 & 14,593 \\
\hline Adjusted R-squared & 0.367 & 0.393 & 0.361 & 0.388 & 0.381 & 0.432 & 0.383 & 0.433 \\
\hline
\end{tabular}




\section{Table 9}

\section{Selection of Banks by Firms by Split Deposits}

The table uses data from January 2005 to June 2010 and reports descriptive statistics in Panel A as well as regression results in Panel B. In Panel A, a transaction is defined as split deposit when the same firm places a deposit with another bank on the same day. It includes only auctions where the firm selects a bank bid and reports statistics for the executed transactions. The statistical significance of the difference in variables is derived for all but the first two variables in the Panel via a t-test for unpaired data with unequal variance. Panel B reports OLS regression results of an indicator variable, which is one when a bid is selected and zero otherwise, on control variables. The data include all auctions where a bid is selected and at least two banks are bidding. All variables are defined in Appendix A1. Bank risk is used with its value on the day prior to the transaction. The relationship variables are derived over the previous year excluding the current transaction. The time fixed effects are based on quarter. The statistical significance of the results is indicated by $*=10 \%$ level, $* *=5 \%$ level and $* * *=1 \%$ level using heteroscedasticityrobust standard errors clustered at the bank-level.

\section{Panel A: Descriptive statistics of split and non-split deposits}

\begin{tabular}{|c|c|c|c|}
\hline & Split deposits & Non-split deposits & Difference \\
\hline Number of auctions & 30,924 & 17,939 & 12,985 \\
\hline $\begin{array}{l}\text { \% of auctions with transaction, not } \\
\text { highest bid selected }\end{array}$ & $18.0 \%$ & $12.5 \%$ & $5.5 \%$ \\
\hline Notional amount per transaction ( $€ m$ ) & 87.2 & 50.6 & $36.6^{* * * *}$ \\
\hline CDS spread of selected bank & 78.150 & 78.985 & -0.835 \\
\hline Bank relationship (trades) & 0.183 & 0.314 & $-0.131 * * *$ \\
\hline Bank relationship (amount) & 0.185 & 0.312 & $-0.128 * * *$ \\
\hline Number of banks bidding per auction & 3.287 & 3.366 & $-0.079 * * *$ \\
\hline Maturity per auction (days) & 6.221 & 5.738 & $0.483^{* * * *}$ \\
\hline
\end{tabular}

Panel B: Selection of banks by split and non-split deposits

\begin{tabular}{|c|c|c|c|c|c|c|c|c|}
\hline \multirow[t]{3}{*}{ Dependent Variable } & \multicolumn{8}{|c|}{$1=$ Executed bid } \\
\hline & \multicolumn{4}{|c|}{ Split deposits } & \multicolumn{4}{|c|}{ Non-split deposits } \\
\hline & I & II & III & IV & $\mathrm{V}$ & VI & VII & VIII \\
\hline \multicolumn{9}{|l|}{ Bank Risk } \\
\hline Bank risk & $-3.2 \mathrm{E}-4$ & & $-1.1 \mathrm{E}-3$ & & $0.011^{* *}$ & & $0.011^{*}$ & \\
\hline Bank risk - within auction & & -0.007 & & -0.007 & & 0.003 & & 0.001 \\
\hline \multicolumn{9}{|l|}{ Transaction Variable } \\
\hline Highest bid of auction & $0.401 * * *$ & $0.452 * * *$ & $0.401 * * *$ & $0.452 * * *$ & $0.449 * * *$ & $0.492 * * *$ & $0.449 * * *$ & $0.493 * * *$ \\
\hline \multicolumn{9}{|l|}{ Relationship } \\
\hline Relationship (trades) & $0.358 * * *$ & $0.367 * * *$ & & & $0.667 * * *$ & $0.652 * * *$ & & \\
\hline Relationship (amount) & & & $0.277 * * *$ & $0.276^{* * *}$ & & & $0.639 * * *$ & $0.625 * * *$ \\
\hline Other Transaction Variables & Yes & Yes & Yes & Yes & Yes & Yes & Yes & Yes \\
\hline Bank-Firm Fixed Effects & Yes & Yes & Yes & Yes & Yes & Yes & Yes & Yes \\
\hline Bank-Time Fixed Effects & Yes & Yes & Yes & Yes & Yes & Yes & Yes & Yes \\
\hline Observations & 79,410 & 43,042 & 79,410 & 43,042 & 47,984 & 26,679 & 47,984 & 26,679 \\
\hline Adjusted R-squared & 0.290 & 0.329 & 0.288 & 0.326 & 0.495 & 0.513 & 0.493 & 0.509 \\
\hline
\end{tabular}




\section{Table 10}

Selection of Banks by Firms when the Highest Bid is Not Selected

The table reports OLS regression results of an indicator variable, which is one when a bid is selected and zero otherwise, on control variables using data from January 2005 to June 2010. The data include all auctions where a bid is selected and at least two banks are bidding but exclude all auctions where the highest bid is selected. A constant is included but omitted. All variables are defined in Appendix A1. Bank risk is used with its value on the day prior to the transaction. The relationship variables are derived over the previous year excluding the current transaction. The time fixed effects are based on quarter. The crisis period in columns V to VIII ranges from August 8, 2007 to June 30,2010 . The statistical significance of the results is indicated by $*=10 \%$ level, $* *=5 \%$ level and $* * *=1 \%$ level using heteroscedasticity-robust standard errors clustered at the bank-level.

\begin{tabular}{|c|c|c|c|c|c|c|c|c|}
\hline \multirow[t]{3}{*}{ Dependent Variable } & \multicolumn{8}{|c|}{$1=$ Executed bid $\mid$ not highest bid selected } \\
\hline & \multicolumn{4}{|c|}{ Total Period } & \multicolumn{4}{|c|}{ Crisis Period } \\
\hline & $\mathrm{I}$ & II & III & IV & $\mathrm{V}$ & VI & VII & VIII \\
\hline \multicolumn{9}{|l|}{ Bank Risk } \\
\hline Bank risk & 0.001 & & -0.001 & & -0.005 & & -0.005 & \\
\hline Bank risk - within auction & & 0.001 & & -0.002 & & -0.009 & & -0.014 \\
\hline \multicolumn{9}{|l|}{ Relationship } \\
\hline Relationship (trades) & $0.821 * * *$ & $0.896 * * *$ & & & $0.791 * * *$ & $0.887 * * *$ & & \\
\hline Relationship (amount) & & & $0.688 * * *$ & $0.791 * * *$ & & & $0.651 * * *$ & $0.792 * * *$ \\
\hline Other Transaction Variables & Yes & Yes & Yes & Yes & Yes & Yes & Yes & Yes \\
\hline Bank-Firm Fixed Effects & Yes & Yes & Yes & Yes & Yes & Yes & Yes & Yes \\
\hline Bank-Time Fixed Effects & Yes & Yes & Yes & Yes & Yes & Yes & Yes & Yes \\
\hline Observations & 38,470 & 16,134 & 38,470 & 16,134 & 29,163 & 10,030 & 29,163 & 10,030 \\
\hline Adjusted R-squared & 0.179 & 0.204 & 0.164 & 0.185 & 0.189 & 0.235 & 0.174 & 0.216 \\
\hline
\end{tabular}




\section{Table 11}

\section{Bidding Highest in an Auction and Relationship Building}

The table only includes the selected bids from auctions where at least two banks are bidding. Panels A and B report OLS regression results of an indicator variable, which is one when the highest bid is selected and zero otherwise, on control variables using data from January 2005 to June 2010. Panel C reports OLS regressions of the deposit spread, defined as deposit interest rate minus the ECB deposit facility interest rate, on control variables using all deposit transactions on the platform since its initiation in the beginning of the 2000's until June 2010. The panel excludes transactions where a firm deposits with a bank more than the $600^{\text {th }}$ time. Further Transaction Variables include the first bid of the auction, the natural logarithm of the number of banks per auction, and the natural logarithm of the notional deposit amount per auction. A constant is included but omitted. All variables are defined in Appendix A1. Bank risk is used with its value on the day prior to the transaction. The relationship variables are derived over the previous year excluding the current transaction. The time fixed effects are based on quarter. Bank characteristics variables are used as stated in the annual report in the year prior to the transaction. The statistical significance of the results is indicated by $*=10 \%$ level, $* *=5 \%$ level and $* * *=1 \%$ level using heteroscedasticity-robust standard errors clustered at the bank-level.

Panel A: Highest bid selected

\begin{tabular}{|c|c|c|c|c|c|c|c|c|}
\hline \multirow[t]{2}{*}{ Dependent Variable } & \multicolumn{8}{|c|}{$1=$ Highest bid selected $\mid$ executed bid } \\
\hline & $\mathrm{I}$ & II & III & IV & $\mathrm{V}$ & VI & VII & VIII \\
\hline \multicolumn{9}{|l|}{ Bank Risk } \\
\hline Bank risk & -0.005 & & & & -0.005 & & -0.005 & \\
\hline Bank risk - within auction & & 0.024 & & & & 0.028 & & 0.026 \\
\hline \multicolumn{9}{|l|}{ Relationship } \\
\hline Relationship (trade) & & & -0.026 & & -0.023 & -0.068 & & \\
\hline Relationship (amount) & & & & -0.009 & & & -0.002 & -0.034 \\
\hline Transaction Variables & Yes & Yes & Yes & Yes & Yes & Yes & Yes & Yes \\
\hline Bank Accounting Variables & Yes & Yes & Yes & Yes & Yes & Yes & Yes & Yes \\
\hline Observations & 23,886 & 16,485 & 25,410 & 25,410 & 23,746 & 16,389 & 23,746 & 16,389 \\
\hline Adjusted R-squared & 0.101 & 0.050 & 0.101 & 0.101 & 0.101 & 0.051 & 0.101 & 0.049 \\
\hline
\end{tabular}

Panel B: Highest bid selected, including fixed effects

\begin{tabular}{|c|c|c|c|c|c|c|c|c|}
\hline \multirow[t]{2}{*}{ Dependent Variable } & \multicolumn{8}{|c|}{$1=$ Highest bid selected $\mid$ executed bid } \\
\hline & I & II & III & IV & $\mathrm{V}$ & VI & VII & VIII \\
\hline Bank Risk & & & & & & & & \\
\hline Bank risk & -0.005 & & & & -0.006 & & -0.005 & \\
\hline Bank risk - within auction & & 0.005 & & & & 0.005 & & 0.005 \\
\hline Relationship & & & & & & & & \\
\hline Relationship (trade) & & & $-0.149 * *$ & & $-0.137 *$ & $-0.187 * * *$ & & \\
\hline Relationship (amount) & & & & $-0.109 * *$ & & & -0.092 & $-0.130 * * *$ \\
\hline Transaction Variables & Yes & Yes & Yes & Yes & Yes & Yes & Yes & Yes \\
\hline Bank-Firm Fixed Effects & Yes & Yes & Yes & Yes & Yes & Yes & Yes & Yes \\
\hline Bank-Time Fixed Effects & Yes & Yes & Yes & Yes & Yes & Yes & Yes & Yes \\
\hline Observations & 28,343 & 19,253 & 31,562 & 31,562 & 28,184 & 19,142 & 28,184 & 19,142 \\
\hline Adjusted R-squared & 0.323 & 0.268 & 0.314 & 0.313 & 0.326 & 0.273 & 0.324 & 0.271 \\
\hline
\end{tabular}

\section{Panel C: Deposit spread}

\begin{tabular}{|c|c|c|c|c|}
\hline Dependent Variable & & & & \\
\hline & $\mathrm{I}$ & II & III & IV \\
\hline Dummy (1=Transactions \#0-100) & $2.764 * * *$ & $2.846^{* * * *}$ & $2.468 * * *$ & $2.887 * * *$ \\
\hline Dummy (1=Transactions \#101-300) & $1.968 * * *$ & $2.058 * * *$ & $2.028 * * *$ & $2.498 * * *$ \\
\hline Dummy (1=Transactions \#301-600) & 1.175 & 1.284 & 0.914 & 1.513 \\
\hline Bank Risk & & & & \\
\hline Bank risk & & & 0.714 & \\
\hline Bank risk - within auction & & & & -0.074 \\
\hline Further Transaction Variables & No & Yes & Yes & Yes \\
\hline Fixed Effects (FE) and Clustering & & & & \\
\hline Bank-Firm Fixed Effects & Yes & Yes & Yes & Yes \\
\hline Bank-Time Fixed Effects & Yes & Yes & Yes & Yes \\
\hline Observations & 159,801 & 159,801 & 127,393 & 69,790 \\
\hline Adjusted R-squared & 0.894 & 0.894 & 0.894 & 0.889 \\
\hline
\end{tabular}




\section{Table 12}

Difference between Successful and Unsuccessful Auctions

The table uses data aggregated to the auction level. It reports OLS regression results of an indicator variable, which is one when a bid is selected in an auction and zero otherwise, on control variables using data from January 2005 to June 2010. The data include all auctions where at least two banks are bidding. The control variables are used with their average value on the auction level. Further transaction variables included in the regressions are the logarithm of the number of bidding banks per auction, the difference between the highest and the lowest bid, and the logarithm of the notional deposit amount. A constant is included but omitted. All variables are defined in Appendix A1. Bank risk is used with its value on the day prior to the transaction prior to its aggregation. The relationship variables are derived over the previous year excluding the current transaction prior to their aggregation. The time fixed effects are based on quarter. The statistical significance of the results is indicated by $*=10 \%$ level, $* *=5 \%$ level and $* * *=$ $1 \%$ level using heteroscedasticity-robust standard errors clustered at the bank-level.

\begin{tabular}{|c|c|c|c|c|}
\hline \multirow[t]{2}{*}{ Dependent Variable } & \multicolumn{4}{|c|}{$1=$ Executed auction } \\
\hline & I & II & III & IV \\
\hline \multicolumn{5}{|l|}{ Bank Risk } \\
\hline Average bank risk & $2.4 \mathrm{E}-4$ & $2.1 \mathrm{E}-3$ & $5.6 \mathrm{E}-4$ & $1.5 \mathrm{E}-4$ \\
\hline \multicolumn{5}{|l|}{ Relationship } \\
\hline Average relationship (trades) & $1.078 * * *$ & & $1.286^{* * *}$ & \\
\hline Average relationship (amount) & & $1.031 * * *$ & & $1.222 * * *$ \\
\hline Further Transaction Variables & No & No & Yes & Yes \\
\hline Average Bank Accounting Variables & Yes & Yes & Yes & Yes \\
\hline Firm Fixed Effects & Yes & Yes & Yes & Yes \\
\hline Time Fixed Effects & Yes & Yes & Yes & Yes \\
\hline Observations & 48,369 & 48,369 & 48,369 & 48,369 \\
\hline Adjusted R-squared & 0.196 & 0.196 & 0.222 & 0.221 \\
\hline
\end{tabular}




\section{Table 13}

\section{Deposit Amount in Future Periods}

The table uses data aggregated to the bank-firm-quarter level. It reports OLS regression results using data from January 2005 to June 2010 . The dependent variable is the logarithm of the total deposit amount a bank receives from a firm on the platform in a quarter. The data include all auctions where a bid is selected and at least two banks are bidding. A constant is included but omitted. Lagged average bank risk is a bank's average CDS spread in the previous quarter. Lagged average relationship is a bank's average relationship with the firm in the previous quarter. Bank characteristics variables are used as stated in the annual report in the year prior to the quarter. The time fixed effects are based on quarter. The crisis period in columns V to VIII ranges from August 8, 2007 to June 30, 2010. The statistical significance of the results is indicated by $*=10 \%$ level, $* *=5 \%$ level and $* * *=1 \%$ level using heteroscedasticity-robust standard errors clustered at the bank-level.

\begin{tabular}{|c|c|c|c|c|c|c|c|c|}
\hline \multirow[t]{3}{*}{ Dependent Variable } & \multicolumn{8}{|c|}{ log (quarterly deposit amount from firm) } \\
\hline & \multicolumn{4}{|c|}{ Total Period } & \multicolumn{4}{|c|}{ During Crisis } \\
\hline & I & II & III & IV & $\mathrm{V}$ & VI & VII & VIII \\
\hline \multicolumn{9}{|l|}{ Bank Risk } \\
\hline Lagged bank risk & & & -0.004 & 0.028 & & & 0.049 & 0.070 \\
\hline \multicolumn{9}{|l|}{ Relationship } \\
\hline Lagged relationship (trades) & $21.868 * * *$ & & $21.749 * * *$ & & $20.402 * * *$ & & $20.371 * * *$ & \\
\hline Lagged relationship (amount) & & $20.413^{* * *}$ & & $20.315^{* * *}$ & & $19.287 * * *$ & & $19.309 * * *$ \\
\hline Bank Accounting Variables & Yes & Yes & Yes & Yes & Yes & Yes & Yes & Yes \\
\hline \multicolumn{9}{|l|}{ Fixed Effects $(F E)$ and Clustering } \\
\hline Bank-Firm Fixed Effects & Yes & Yes & Yes & Yes & Yes & Yes & Yes & Yes \\
\hline Firm-Time Fixed Effects & Yes & Yes & Yes & Yes & Yes & Yes & Yes & Yes \\
\hline Observations & 3,723 & 3,723 & 3,490 & 3,490 & 2,726 & 2,726 & 2,594 & 2,594 \\
\hline Adjusted R-squared & 0.407 & 0.399 & 0.401 & 0.392 & 0.440 & 0.434 & 0.439 & 0.432 \\
\hline
\end{tabular}




\section{Appendix A1.}

\section{Description of Variables}

The table describes all variables and their units of measurement. All financial variables are measured in real terms with 2005 as base year, using the Consumer Price Index (CPI) as published by the OECD.

\begin{tabular}{|c|c|c|}
\hline Variable Name & Unit & Description \\
\hline \multicolumn{3}{|l|}{ Dependent Variables } \\
\hline Executed bid & Dummy & Dummy variable, which is one when a bid is selected in an auction, and zero otherwise. \\
\hline $\begin{array}{l}\text { Executed bid I not highest } \\
\text { bid selected }\end{array}$ & Dummy & $\begin{array}{l}\text { Dummy variable, which is one when a bid is selected in an auction, and zero otherwise } \\
\text { (excludes auctions where the highest bid is selected). }\end{array}$ \\
\hline $\begin{array}{l}\text { Highest bid selected I } \\
\text { executed bid }\end{array}$ & Dummy & $\begin{array}{l}\text { Dummy variable, which is one when the highest bid is selected in an auction, and zero } \\
\text { otherwise (includes only executed bids). }\end{array}$ \\
\hline Deposit spread & bps & Deposit rate less the European Central Bank (ECB) deposit facility rate. \\
\hline Executed auction & Dummy & Dummy variable, which is one for all bids in an executed auction, and zero otherwise. \\
\hline $\begin{array}{l}\text { Log (quarterly deposit } \\
\text { amount from firm) }\end{array}$ & $\log (€ \mathrm{~m})$ & $\begin{array}{l}\text { Natural logarithm of the sum of deposit amount received by a bank from a respective firm } \\
\text { within a quarter. }\end{array}$ \\
\hline \multicolumn{3}{|l|}{ Bank Risk Variables } \\
\hline Average bank risk & $\log (\mathrm{bps})$ & $\begin{array}{l}\text { Mean bank risk of banks bidding in an auction, where bank risk is defined as the natural } \\
\text { logarithm of a banks' credit default swap spreads with a five-year maturity. }\end{array}$ \\
\hline Bank risk & $\log (b p s)$ & Natural logarithm of a banks' credit default swap spreads with a five-year maturity. \\
\hline Bank risk (rating) & \# & $\begin{array}{l}\text { Integer variable derived from Moody's long-term issuer ratings. The measure ranges from } \\
\text { zero to } 21 \text {, with } 21 \text { assigned to a Aaa rating. }\end{array}$ \\
\hline Bank risk - within auction & $\log (\#+1)$ & $\begin{array}{l}\text { All bidding banks in a transaction are ranked from lowest to highest using the banks' CDS } \\
\text { spread with a five-year maturity. A bank's risk rank in a transaction is then calculated by } \\
\text { taking the natural logarithm of each bank's rank, plus } 1 \text {. }\end{array}$ \\
\hline $\begin{array}{l}\text { Bank risk - within auction } \\
\text { (rating) }\end{array}$ & $\log (\#+1)$ & $\begin{array}{l}\text { All bidding banks in a transaction are ranked from lowest to highest using the banks' long- } \\
\text { term issuer rating. A bank's risk rank in a transaction is then calculated by taking the natural } \\
\text { logarithm of each bank's rank, plus } 1 \text {. }\end{array}$ \\
\hline Change $>5 \%$ above median & Dummy & $\begin{array}{l}\text { Dummy variable which is one when the percentage change of a bank's CDS spread is more } \\
\text { than } 5 \text { percentage points above the median percentage change of CDS spreads of all our } \\
\text { sample banks over the same time interval (weekly, quarterly), and zero otherwise. }\end{array}$ \\
\hline GIIPS bank & Dummy & $\begin{array}{l}\text { Dummy variable which is one when a bank is headquartered in Greece, Ireland, Italy, } \\
\text { Portugal, or Spain, and zero otherwise. }\end{array}$ \\
\hline Increase $>20 \%$ & Dummy & $\begin{array}{l}\text { Dummy variable which is one when a bank's CDS spread increases more than } 20 \% \text { over a } \\
\text { specified time interval (weekly, quarterly), and zero otherwise. }\end{array}$ \\
\hline Increase $>70 \%$ & Dummy & $\begin{array}{l}\text { Dummy variable which is one when a bank's CDS spread increases more than } 70 \% \text { over a } \\
\text { specified time interval (weekly, quarterly), and zero otherwise. }\end{array}$ \\
\hline Lagged bank risk & $\log (b p s)$ & $\begin{array}{l}\text { Average bank risk during the prior quarter/month, where bank risk is defined as the natural } \\
\text { logarithm of a banks' credit default swap spreads with a five-year maturity. }\end{array}$ \\
\hline $\log (\mathrm{z}$-score $)$ & $\log (\%)$ & $\begin{array}{l}\text { Natural logarithm of the sum of the return on assets and the ratio of total equity to total assets } \\
\text { divided by the standard deviation of the return on assets. The last } 10 \text { years for the latter's } \\
\text { derivation in each year is used. }\end{array}$ \\
\hline \multicolumn{3}{|l|}{ Relationship Variables } \\
\hline $\begin{array}{l}\text { Average relationship } \\
\text { (amount) }\end{array}$ & $\%$ & Average relationship (amount) of banks bidding in an auction. \\
\hline $\begin{array}{l}\text { Average relationship } \\
\text { (trades) }\end{array}$ & $\%$ & Average relationship (trades) of banks bidding in an auction. \\
\hline $\begin{array}{l}\text { Lagged relationship } \\
\text { (amount) }\end{array}$ & $\%$ & $\begin{array}{l}\text { Average relationship (amount) over all bids between a bank and a firm during the prior } \\
\text { quarter/month. }\end{array}$ \\
\hline Lagged relationship (trades) & $\%$ & $\begin{array}{l}\text { Average relationship (trades) over all bids between a bank and a firm during the prior } \\
\text { quarter/month. }\end{array}$ \\
\hline Relationship (amount) & $\%$ & $\begin{array}{l}\text { Notional amount of deposit transactions with a respective bank over the last year divided by } \\
\text { the notional amount of all deposit transactions of the firm over the last year, excluding the } \\
\text { current transaction in both cases. }\end{array}$ \\
\hline Relationship (trades) & $\%$ & $\begin{array}{l}\text { Number of deposit transactions with a respective bank over the last year divided by the } \\
\text { number of all deposit transactions of the firm over the last year, excluding the current } \\
\text { transaction in both cases. }\end{array}$ \\
\hline \multicolumn{3}{|l|}{ Transaction Variables } \\
\hline $\begin{array}{l}\text { Dummy }(1=\text { Transactions } \\
\# 0-100)\end{array}$ & Dummy & $\begin{array}{l}\text { Dummy variable which is one for all bank-firm transaction between } 0 \text { and } 100 \text {, and zero } \\
\text { otherwise. }\end{array}$ \\
\hline $\begin{array}{l}\text { Dummy (1=Transactions } \\
\# 101-300)\end{array}$ & Dummy & $\begin{array}{l}\text { Dummy variable which is one for all bank-firm transaction between } 101 \text { and 300, and zero } \\
\text { otherwise. }\end{array}$ \\
\hline $\begin{array}{l}\text { Dummy }(1=\text { Transactions } \\
\# 301-600)\end{array}$ & Dummy & $\begin{array}{l}\text { Dummy variable which is one for all bank-firm transaction between } 301 \text { and } 600 \text {, and zero } \\
\text { otherwise. }\end{array}$ \\
\hline Extremely high bid & Dummy & $\begin{array}{l}\text { Dummy variable which is one if the highest bank bid is } 50 \% \text { above the median interest rate of } \\
\text { all bids in this auction, and zero otherwise. }\end{array}$ \\
\hline
\end{tabular}




\begin{tabular}{|c|c|c|}
\hline First bid of auction & Dummy & Dummy variable, which is one for the first bid in a deposit auction, and zero otherwise. \\
\hline Highest bid of auction & Dummy & Dummy variable, which is one for the highest bid in a deposit auction, and zero otherwise. \\
\hline $\begin{array}{l}\text { Log (number banks per } \\
\text { auction) }\end{array}$ & $\log (\#)$ & $\begin{array}{l}\text { Natural logarithm of the number of bidding banks in an auction. Each bidding bank is } \\
\text { included only once in this calculation irrespective of the number of bids per bank within an } \\
\text { auction. }\end{array}$ \\
\hline Log (notional amount) & $\log (€ \mathrm{~m})$ & Natural logarithm of the notional deposit amount offered by the firm in a deposit auction. \\
\hline $\begin{array}{l}\text { Difference between lowest } \\
\text { and highest bid per auction }\end{array}$ & bps & Deposit rate of the highest bid less the deposit rate of the lowest bid in an auction. \\
\hline \multicolumn{3}{|l|}{ Bank Accounting Variables } \\
\hline Asset growth & $\%$ & Annual asset growth as calculated by Bankscope based on annual balance sheet data. \\
\hline $\begin{array}{l}\text { BS derivative exposure / } \\
\text { total assets }\end{array}$ & $\%$ & $\begin{array}{l}\text { Ratio of the difference between derivative assets and derivative liabilities to total assets as } \\
\text { recorded in Bankscope. }\end{array}$ \\
\hline Cost / income ratio & $\%$ & $\begin{array}{l}\text { Ratio of administrative costs to income excluding increase of risk provisions as calculated by } \\
\text { Bankscope. }\end{array}$ \\
\hline Leverage & $\%$ & Ratio of total liabilities to total assets as recorded in Bankscope. \\
\hline Log (total assets) & $\log (€ \mathrm{~m})$ & Natural logarithm of the bank's total assets in $€$-million as recorded in Bankscope. \\
\hline Net interest margin & $\%$ & Net interest margin as calculated by Bankscope. \\
\hline $\begin{array}{l}\text { Net loans / customer } \\
\text { deposits }\end{array}$ & $\%$ & Ratio of net loans to customer deposits as calculated by Bankscope. \\
\hline $\begin{array}{l}\text { Non-performing loans / } \\
\text { total loans }\end{array}$ & $\%$ & Ratio of non-performing loans to gross loans as calculated by Bankscope. \\
\hline OBS exposure & $\%$ & $\begin{array}{l}\text { Ratio of off-balance-sheet items divided by the sum of total assets and off-balance-sheet } \\
\text { items. The amount of off-balance-sheet items is used as recorded in Bankscope. It is } \\
\text { calculated as the sum of managed securitized assets reported off-balance-sheet, other off- } \\
\text { balance-sheet exposure to securitizations, guarantees, acceptances and documentary credits } \\
\text { reported off-balance-sheet, committed credit lines, and other contingent liabilities. }\end{array}$ \\
\hline Return on equity & $\%$ & Calculated as net income divided by equity as recorded in Bankscope. \\
\hline \multicolumn{3}{|l|}{ Descriptive Variables } \\
\hline \multicolumn{3}{|l|}{$\begin{array}{l}\text { Firm-related transaction } \\
\text { variables }\end{array}$} \\
\hline $\begin{array}{l}\% \text { of auctions with } \\
\text { transaction }\end{array}$ & $\%$ & Number of auctions with transaction divided by the total number of auctions. \\
\hline $\begin{array}{l}\% \text { of auctions with } \\
\text { transaction, not highest bid } \\
\text { selected }\end{array}$ & $\%$ & $\begin{array}{l}\text { Number of auctions with transaction where not the highest bid was selected divided by the } \\
\text { total number of executed auctions. }\end{array}$ \\
\hline Maturity per auction (days) & Days & Average maturity of auctions, measured by the number of trading days. \\
\hline $\begin{array}{l}\text { Maturity per auction with } \\
\text { transaction (days) }\end{array}$ & Days & Average maturity of auctions with transaction, measured by the number of trading days. \\
\hline $\begin{array}{l}\text { Notional amount per } \\
\text { auction }(€ \mathrm{~m})\end{array}$ & $€ \mathrm{~m}$ & Average notional deposit amount offered by firms per auction. \\
\hline $\begin{array}{l}\text { Notional amount per } \\
\text { auction with transaction }(€ \\
\mathrm{m})\end{array}$ & $€ \mathrm{~m}$ & Average notional deposit amount offered by firms per auction with transaction. \\
\hline $\begin{array}{l}\text { Number of auctions per } \\
\text { quarter }\end{array}$ & \# & Total number of auctions offered by firms per quarter. \\
\hline $\begin{array}{l}\text { Number of auctions per } \\
\text { firm-quarter }\end{array}$ & \# & Average number of auctions offered by firms per quarter. \\
\hline $\begin{array}{l}\text { Number of auctions with } \\
\text { transaction per firm-quarter }\end{array}$ & \# & Average number of auctions with transaction offered by firms per quarter. \\
\hline $\begin{array}{l}\text { Number of firms offering } \\
\text { deposits } \\
\text { Bank-related transaction } \\
\text { variables }\end{array}$ & \# & Number of firms that offered a notional deposit amount at least once. \\
\hline $\begin{array}{l}\text { Number of banks bidding } \\
\text { for deposits }\end{array}$ & \# & Number of banks that bid in auctions at least once. \\
\hline $\begin{array}{l}\text { Number of bids per bank- } \\
\text { quarter }\end{array}$ & \# & Average number of bank bids per quarter. \\
\hline $\begin{array}{l}\text { Number of bids per quarter } \\
\text { Further transaction variables }\end{array}$ & \# & Total number of bank bids per quarter. \\
\hline $\begin{array}{l}\text { Deposit interest rate per } \\
\text { auction (bps) }\end{array}$ & bps & Average deposit interest rate of all bids per auction. \\
\hline $\begin{array}{l}\text { Number of bidding banks } \\
\text { per auction }\end{array}$ & \# & Average number of bidding banks per auction. \\
\hline
\end{tabular}


Appendix A2.

Exemplary Deposit Auction

The table shows an exemplary deposit transaction for illustrative purposes.

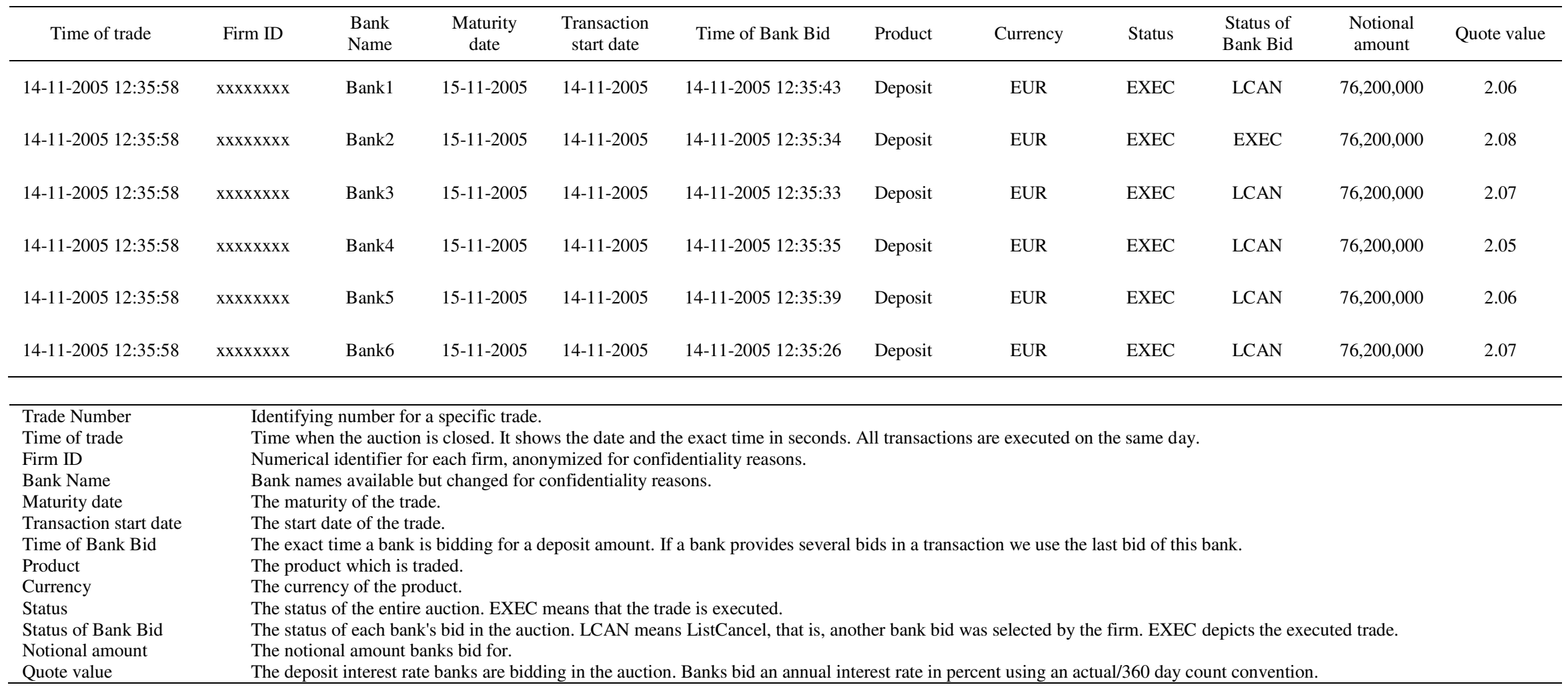




\section{Appendix A3.}

Example for the Derivation of the "Bank risk-within auction"-Variable

The table shows an exemplary auction with 10 bidding banks to illustrate the derivation of the "Bank risk - within auction"-variable.

\begin{tabular}{cccc}
\hline Bank Name & $\begin{array}{c}\text { Credit default swap spread on the banks' } \\
\text { senior unsecured debt with a 5 year } \\
\text { maturity }\end{array}$ & Bank risk rank & $\begin{array}{c}\text { Bank risk - within auction } \\
=1+\log \text { (bank risk rank) }\end{array}$ \\
\hline Bank1 & 14 & 1 & 1.000 \\
Bank2 & 15.1 & 2 & 1.693 \\
Bank3 & 15.2 & 3 & 2.099 \\
Bank4 & 16.1 & 4 & 2.386 \\
Bank5 & 16.1 & 4 & 2.386 \\
Bank6 & 16.1 & 4 & 2.386 \\
Bank7 & 23.8 & 7 & 2.946 \\
Bank8 & 23.8 & 7 & 2.946 \\
Bank9 & 26 & 9 & 3.197 \\
Bank10 & 26 & 9 & 3.197 \\
\hline
\end{tabular}




\title{
Do corporate depositors risk everything for nothing? The importance of deposit relationships, interest rates and bank risk
}

\author{
Daniel Friedmann $^{\# \quad \text { Björn Imbierowicz }}{ }^{\ddagger}$ Anthony Saunders* Sascha Steffen ${ }^{\circ}$
}

\footnotetext{
\# Goethe University Frankfurt, House of Finance, Theodor-W.-Adorno-Platz 3, 60323 Frankfurt (Germany), Email: danielfriedmann@ hotmail.com, Tel.: +49 6979833729.

† Copenhagen Business School, Finance Department and Center for Financial Frictions (FRIC), Solbjerg Plads 3, 2000 Frederiksberg, Copenhagen (Denmark), Email: bi.fi@cbs.dk, Tel: +45 38153736.

* John M. Schiff Professor of Finance, Department of Finance, New York University, Stern School of Business, 44 West 4th St., New York, NY 10012 (USA), Email: asaunder@ @stern.nyu.edu, Tel: +1-212-998-0711.

- University of Mannheim \& ZEW, L7, 1, 68161 Mannheim (Germany), Email: steffen@zew.de, Tel: +49 (0)621 1235-140.
} 


\section{NOT FOR PUBLICATION}

\section{Addition to Table 2}

\section{Selection of Banks by Firms}

The table reports OLS regression results of an indicator variable, which is one when a bid is selected and zero otherwise, on control variables using data from January 2005 to June 2010. The data include all auctions where a bid is selected and at least two banks are bidding. All variables are defined in Appendix A1. Bank risk is used with its value on the day prior to the transaction. The relationship variables are derived over the previous year excluding the current transaction. The time fixed effects in Panels A to $\mathrm{C}$ are based on month. The crisis period in Panel B ranges from August 8, 2007 to June 30, 2010. The period 6 months after the default of Lehman Brothers in Panel C ranges from September 15, 2008 to March 15, 2009. The statistical significance of the results is indicated by $*=10 \%$ level, $* *=5 \%$ level and $* * *=1 \%$ level using heteroscedasticity-robust standard errors clustered at the bank-level.

\section{Panel A: Total period}

\begin{tabular}{|c|c|c|c|c|c|c|c|c|c|}
\hline \multirow[t]{2}{*}{ Dependent Variable } & \multicolumn{9}{|c|}{$1=$ Executed bid } \\
\hline & I & II & III & IV & $\mathrm{V}$ & VI & VII & VIII & IX \\
\hline Bank Risk & & & & & & & & & 7 \\
\hline Bank risk & & 0.004 & & & & 0.004 & & 0.003 & \\
\hline Bank risk - within auction & & & -0.001 & & & & -0.002 & & -0.003 \\
\hline Transaction Variable & & & & & & & & & \\
\hline Highest bid of auction & $0.430 * * *$ & $0.438 * * *$ & $0.485 * * *$ & $0.412 * * *$ & $0.413 * * *$ & $0.420 * * *$ & $0.469 * * *$ & $0.420 * * *$ & $0.469 * * *$ \\
\hline Relationship & & & & & & & & & \\
\hline Relationship (trades) & & & & $0.585^{* * *} *$ & & $0.594 * * *$ & $0.594 * * *$ & & \\
\hline Relationship (amount) & & & & & $0.530 * * *$ & & & $0.541 * * *$ & $0.549 * * *$ \\
\hline Other Transaction Variables & Yes & Yes & Yes & Yes & Yes & Yes & Yes & Yes & Yes \\
\hline Bank-Firm Fixed Effects & Yes & Yes & Yes & Yes & Yes & Yes & Yes & Yes & Yes \\
\hline Bank-Time Fixed Effects & Yes & Yes & Yes & Yes & Yes & Yes & Yes & Yes & Yes \\
\hline Observations & 145,434 & 127,992 & 70,051 & 144,744 & 144,744 & 127,394 & 69,721 & 127,394 & 69,721 \\
\hline Adjusted R-squared & 0.325 & 0.331 & 0.361 & 0.358 & 0.355 & 0.365 & 0.397 & 0.362 & 0.393 \\
\hline
\end{tabular}

Panel B: Crisis period

\begin{tabular}{|c|c|c|c|c|c|c|c|c|c|}
\hline \multirow[t]{2}{*}{ Dependent Variable } & \multicolumn{9}{|c|}{$1=$ Executed bid } \\
\hline & I & II & III & IV & $\mathrm{V}$ & VI & VII & VIII & IX \\
\hline \multicolumn{10}{|l|}{ Bank Risk } \\
\hline Bank risk & & -0.002 & & & & -0.003 & & -0.003 & \\
\hline Bank risk - within auction & & & -0.01 & & & & -0.008 & & -0.010 \\
\hline \multicolumn{10}{|l|}{ Transaction Variable } \\
\hline Highest bid of auction & $0.469 * * *$ & $0.488 * * *$ & $0.541 * * *$ & $0.448 * * *$ & $0.449 * * *$ & $0.467 * * *$ & $0.524 * * *$ & $0.468 * * *$ & $0.524 * * *$ \\
\hline \multicolumn{10}{|l|}{ Relationship } \\
\hline Relationship (trades) & & & & $0.605 * * *$ & & $0.604 * * *$ & $0.601 * * *$ & & \\
\hline Relationship (amount) & & & & & $0.541 * * *$ & & & $0.538 * * *$ & $0.550 * * *$ \\
\hline Other Transaction Variables & Yes & Yes & Yes & Yes & Yes & Yes & Yes & Yes & Yes \\
\hline Bank-Firm Fixed Effects & Yes & Yes & Yes & Yes & Yes & Yes & Yes & Yes & Yes \\
\hline Bank-Time Fixed Effects & Yes & Yes & Yes & Yes & Yes & Yes & Yes & Yes & Yes \\
\hline Observations & 95,795 & 84,069 & 44,901 & 95,384 & 95,384 & 83,706 & 44,704 & 83,706 & 44,704 \\
\hline Adjusted R-squared & 0.332 & 0.349 & 0.403 & 0.370 & 0.366 & 0.387 & 0.444 & 0.382 & 0.439 \\
\hline
\end{tabular}

Panel C: Period 6 months after default of Lehman Brothers

\begin{tabular}{|c|c|c|c|c|}
\hline \multirow[t]{2}{*}{ Dependent Variable } & \multicolumn{4}{|c|}{$1=$ Executed bid } \\
\hline & $\mathrm{I}$ & II & III & IV \\
\hline \multicolumn{5}{|l|}{ Bank Risk } \\
\hline Bank risk & -0.026 & & -0.030 & \\
\hline Bank risk - within auction & & -0.002 & & -0.009 \\
\hline \multicolumn{5}{|l|}{ Transaction Variable } \\
\hline Highest bid of auction & $0.372 * * *$ & $0.433 * * *$ & $0.374 * * *$ & $0.436 * * *$ \\
\hline \multicolumn{5}{|l|}{ Relationship } \\
\hline Relationship (trades) & $0.604 * * *$ & $0.592 * * *$ & & \\
\hline Relationship (amount) & & & $0.486^{* * * *}$ & $0.510 * * *$ \\
\hline Other Transaction Variables & Yes & Yes & Yes & Yes \\
\hline Bank-Firm Fixed Effects & Yes & Yes & Yes & Yes \\
\hline Bank-Time Fixed Effects & Yes & Yes & Yes & Yes \\
\hline Observations & 14,358 & 6,557 & 14,358 & 6,557 \\
\hline Adjusted R-squared & 0.285 & 0.308 & 0.276 & 0.301 \\
\hline
\end{tabular}




\section{NOT FOR PUBLICATION}

\section{Addition to Table 3}

\section{Selection of Banks by Firms - Relationship and Bank Risk}

The table reports OLS regression results of an indicator variable, which is one when a bid is selected and zero otherwise, on control variables using data from January 2005 to June 2010. The data include all auctions where a bid is selected and at least two banks are bidding. A constant is included but omitted. All variables are defined in Appendix A1. Bank risk is used with its value on the day prior to the transaction. The relationship variables are derived over the previous year excluding the current transaction. The time fixed effects are based on month. The crisis period in Columns V to VIII ranges from August 8, 2007 to June 30, 2010. The statistical significance of the results is indicated by $*=10 \%$ level, $* *=5 \%$ level and $* * *=1 \%$ level using heteroscedasticity-robust standard errors clustered at the bank-level.

\begin{tabular}{|c|c|c|c|c|c|c|c|c|}
\hline \multirow[t]{3}{*}{ Dependent Variable } & \multicolumn{8}{|c|}{$1=$ Executed bid } \\
\hline & \multicolumn{4}{|c|}{ Total Period } & \multicolumn{4}{|c|}{ Crisis Period } \\
\hline & I & II & III & IV & V & VI & VII & VIII \\
\hline \multicolumn{9}{|l|}{ Bank Risk } \\
\hline Bank risk & 0.001 & & 0.002 & & -0.005 & & -0.003 & \\
\hline Bank risk - within auction & & 0.005 & & 0.005 & & -0.008 & & -0.007 \\
\hline \multicolumn{9}{|l|}{ Transaction Variable } \\
\hline Highest bid of auction & $0.420 * * *$ & $0.469 * * *$ & $0.420 * * *$ & $0.469 * * *$ & $0.467 * * *$ & $0.524 * * *$ & $0.468 * * *$ & $0.524 * * *$ \\
\hline \multicolumn{9}{|l|}{ Relationship } \\
\hline Relationship (trades) & $0.481 * * *$ & $0.675 * * *$ & & & $0.521 * * *$ & $0.610 * * *$ & . & \\
\hline Relationship (amount) & & & $0.488 * * *$ & $0.647 * * *$ & & & $0.535 * * *$ & $0.577 * * *$ \\
\hline \multicolumn{9}{|c|}{ Relationship-Bank Risk Interaction } \\
\hline $\begin{array}{l}\text { Relationship (trades) * } \\
\text { bank risk }\end{array}$ & 0.028 & & & & 019 & & & \\
\hline $\begin{array}{l}\text { Relationship (trades) * } \\
\text { bank risk-within auction }\end{array}$ & & -0.047 & & & & -0.005 & & \\
\hline $\begin{array}{l}\text { Relationship (amount) * } \\
\text { bank risk }\end{array}$ & & & 0.013 & & & & 0.001 & \\
\hline $\begin{array}{l}\text { Relationship (amount) * } \\
\text { bank risk - within auction }\end{array}$ & & & & & & & & -0.016 \\
\hline Other Transaction Variables & Yes & Yes & Yes & Yes & Yes & Yes & Yes & Yes \\
\hline Bank-Firm Fixed Effects & Yes & Yes & Yes & Yes & Yes & Yes & Yes & Yes \\
\hline Bank-Time Fixed Effects & Yes & Yes & Yes & Yes & Yes & Yes & Yes & Yes \\
\hline Observations & 127,394 & 69,721 & 127,394 & 69,721 & 83,706 & 44,704 & 83,706 & 44,704 \\
\hline Adjusted R-squared & 0.365 & 0.397 & 0.362 & 0.393 & 0.387 & 0.444 & 0.382 & 0.439 \\
\hline
\end{tabular}




\section{NOT FOR PUBLICATION}

\section{Addition to Table 4}

Selection of Banks by Firms - Alternative Bank Risk Measures

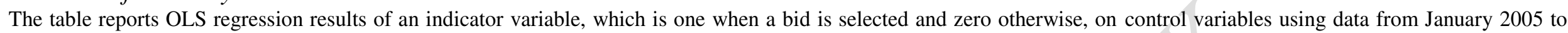
June 2010. The data include all auctions where a bid is selected and at least two banks are bidding. A constant is included but omitted. All variables are defined in Appendix A1. Bank risk is used with its value on the day prior to the transaction. The relationship variables are derived over the previous year excluding the current transaction. The time fixed

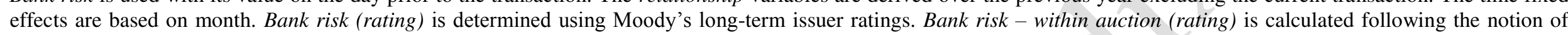
Appendix A3 using these ratings. Non-performing loans are calculated as a fraction of the bank's gross loans. Leverage is calculated as a bank's total liabilities over total assets.

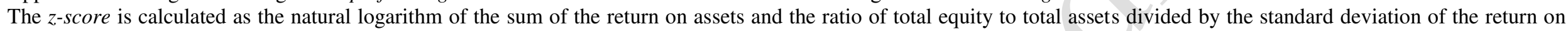
assets. We use the previous 10 years for the latter's derivation in each year. The statistical significance of the results is indicated by $*=10 \%$ level, $* *=5 \%$ level and $* * *=1 \%$ level using heteroscedasticity-robust standard errors clustered at the bank-level.

\begin{tabular}{|c|c|c|c|c|c|c|c|c|c|c|c|c|c|c|c|}
\hline \multirow[t]{2}{*}{ Dependent Variable } & \multicolumn{15}{|c|}{$1=$ Executed bid } \\
\hline & I & II & III & IV & $\mathrm{V}$ & VI & $\begin{array}{l}\text { VII } \\
\end{array}$ & VIII & IX & $\mathrm{X}$ & XI & XII & XIII & XIV & $\mathrm{XV}$ \\
\hline \multicolumn{16}{|l|}{ Bank Risk } \\
\hline Bank risk (rating) & $-3.4 \mathrm{E}-3$ & 7.6E-4 & $-1.7 \mathrm{E}-4$ & & & & & & & & & & & & \\
\hline Bank risk - within auction (rating) & & & & $-4.2 \mathrm{E}-3$ & $-1.5 \mathrm{E}-3$ & $-4.5 \mathrm{E}-4$ & & & & & & & & & \\
\hline Non-performing loans / total loans & & & & & & & 839 & $0.826^{* * *}$ & $0.932 * *$ & & & & & & \\
\hline Leverage & & & & & & & & & & -0.513 & -0.401 & -0.320 & & & \\
\hline $\log (z$-score $)$ & & & & & & & & & & & & & -0.004 & -0.003 & -0.003 \\
\hline \multicolumn{16}{|l|}{ Transaction Variable } \\
\hline & & $0.579 * * *$ & & & $0.560 * * *$ & & & \\
\hline Relationship (amount) & & & $0.529 * * *$ & & & $0.515 * * *$ & & & $0.538 * * *$ & & & $0.534 * * *$ & & & $0.516^{* * *}$ \\
\hline Other Transaction Variables & Yes & Yes & Yes & Yes & Yes & Yes & Yes & Yes & Yes & Yes & Yes & Yes & Yes & Yes & Yes \\
\hline Bank-Firm Fixed Effects & Yes & Yes & Yes & Yes & Yes & Yes & Yes & Yes & Yes & Yes & Yes & Yes & Yes & Yes & Yes \\
\hline Time Fixed Effects & Yes & Yes & Yes & Yes & Yes & Yes & Yes & Yes & Yes & Yes & Yes & Yes & Yes & Yes & Yes \\
\hline Observations & 136,295 & 135,651 & 135,651 & 105,371 & 104,887 & 104,887 & 128,613 & 127,991 & 127,991 & 145,232 & 144,542 & 144,542 & 99,550 & 99,113 & 99,113 \\
\hline Adjusted R-squared & 0.322 & 0.358 & 0.355 & 0.335 & 0.368 & 0.366 & 0.321 & 0.358 & 0.354 & 0.319 & 0.356 & 0.353 & 0.325 & 0.356 & 0.352 \\
\hline
\end{tabular}




\section{NOT FOR PUBLICATION}

\section{Addition to Table 5}

\section{Selection of Banks by Firms - GIIPS banks}

The table reports OLS regression results of an indicator variable, which is one when a bid is selected and zero otherwise, on control variables using data from January 2005 to June 2010. The data include all auctions where a bid is selected and at least two banks are bidding. A constant is included but omitted. All variables are defined in Appendix A1. Bank risk is used with its value on the day prior to the transaction. The relationship variables are derived over the previous year excluding the current transaction. The time fixed effects are based on month. GIIPS bank is a dummy variable which is one when the bank is headquartered in Greece, Ireland, Italy, Portugal, or Spain, and zero otherwise. The crisis period in Panel B ranges from August 8, 2007 to June 30, 2010. The statistical significance of the results is indicated by $*=10 \%$ level, $* *=5 \%$ level and $* * *=1 \%$ level using heteroscedasticity-robust standard errors clustered at the bank-level.

\section{Panel A: Total period}

\begin{tabular}{|c|c|c|c|c|}
\hline \multirow[t]{2}{*}{ Dependent Variable } & \multicolumn{4}{|c|}{$1=$ Executed bid } \\
\hline & I & II & III & IV \\
\hline \multicolumn{5}{|l|}{ Bank Risk } \\
\hline Bank risk & -0.003 & & -0.002 & \\
\hline Bank risk - within auction & & -0.003 & & -0.002 \\
\hline \multicolumn{5}{|l|}{ Transaction Variable } \\
\hline Highest bid of auction & $0.425 * * *$ & $0.478 * * *$ & $0.426 * * *$ & $0.478 * * *$ \\
\hline \multicolumn{5}{|l|}{ Relationship } \\
\hline Relationship (trades) & $0.572 * * *$ & $0.561 * * *$ & & \\
\hline Relationship (amount) & & & $0.533 * * *$ & $0.525 * * *$ \\
\hline \multicolumn{5}{|l|}{ Bank Headquarter } \\
\hline GIIPS bank & 0.068 & $0.155^{*}$ & 0.088 & $0.151^{*}$ \\
\hline \multicolumn{5}{|l|}{ Bank Risk - Bank Headquarter Interaction } \\
\hline Bank risk * GIIPS bank & -0.008 & & -0.012 & \\
\hline Bank risk - within auction $*$ GIIPS bank & & -0.071 & & -0.072 \\
\hline \multicolumn{5}{|l|}{ Highest Bid - Bank Headquarter Interaction } \\
\hline Highest bid of auction * GIIPS bank & 0.055 & 0.016 & 0.048 & 0.013 \\
\hline Bank Accounting Variables & Yes & Yes & Yes & Yes \\
\hline Other Transaction Variables & Yes & Yes & Yes & Yes \\
\hline Firm Fixed Effects & Yes & Yes & Yes & Yes \\
\hline Time Fixed Effects & Yes & Yes & Yes & Yes \\
\hline Observations & 104,577 & 57,552 & 104,577 & 57,552 \\
\hline Adjusted R-squared & 0.364 & 0.401 & 0.362 & 0.398 \\
\hline \multicolumn{5}{|l|}{ Panel B: Crisis period } \\
\hline \multirow[t]{2}{*}{ Dependent Variable } & 7 & \multicolumn{2}{|c|}{$1=$ Executed bid } & \\
\hline & $\mathrm{I}$ & II & III & IV \\
\hline \multicolumn{5}{|l|}{ Bank Risk } \\
\hline Bank risk & -0.005 & & -0.004 & \\
\hline Bank risk - within auction & & -0.006 & & -0.003 \\
\hline \multicolumn{5}{|l|}{ Transaction Variable } \\
\hline Highest bid of auction & $0.459 * * *$ & $0.522 * * *$ & $0.461 * * *$ & $0.523 * * *$ \\
\hline \multicolumn{5}{|l|}{ Relationship } \\
\hline Relationship (trades) & $0.551 * * *$ & $0.546^{* * *}$ & & \\
\hline Relationship (amount) & & & $0.507 * * *$ & $0.508 * * *$ \\
\hline \multicolumn{5}{|l|}{ Bank Headquarter } \\
\hline GIIPS bank & 0.033 & $0.164 *$ & 0.059 & $0.164 *$ \\
\hline \multicolumn{5}{|l|}{ Bank Risk - Bank Headquarter Interaction } \\
\hline Bank risk * GIIPS bank & -0.001 & & -0.006 & \\
\hline Bank risk - within auction * GIIPS bank & & -0.074 & & -0.076 \\
\hline \multicolumn{5}{|l|}{ Highest Bid - Bank Headquarter Interaction } \\
\hline Highest bid of auction * GIIPS bank & 0.029 & -0.017 & 0.021 & -0.022 \\
\hline Bank Accounting Variables & Yes & Yes & Yes & Yes \\
\hline Other Transaction Variables & Yes & Yes & Yes & Yes \\
\hline Firm FE & Yes & Yes & Yes & Yes \\
\hline Time FE & Yes & Yes & Yes & Yes \\
\hline Observations & 77,649 & 41,693 & 77,649 & 41,693 \\
\hline Adjusted R-squared & 0.379 & 0.439 & 0.375 & 0.434 \\
\hline
\end{tabular}




\section{NOT FOR PUBLICATION}

Addition to Table 6

Selection of Banks by Firms - Intensive Margin

The table reports OLS regression results of an indicator variable, which is one when a bid is selected and zero otherwise, on control variables using data from January 2005 to June 2010. A bank is defined to be on the intensive margin when it assumes deposits via the trading platform in the period prior to as well as in the financial crisis. The data include all auctions where a bid is selected and at least two banks are bidding. A constant is included but omitted. All variables are defined in Appendix A1. Bank risk is used with its value on the day prior to the transaction. The relationship variables are derived over the previous year excluding the current transaction. The time fixed effects are based on month. The statistical significance of the results is indicated by $*=10 \%$ level, $* *=5 \%$ level and $* * *=1 \%$ level using heteroscedasticity-robust standard errors clustered at the bank-level.

\begin{tabular}{|c|c|c|c|c|c|c|c|c|c|}
\hline \multirow[t]{2}{*}{ Dependent Variable } & \multicolumn{9}{|c|}{$1=$ Executed bid } \\
\hline & $\mathrm{I}$ & II & III & IV & $\mathrm{V}$ & VI & VII & VIII & IX \\
\hline \multicolumn{10}{|l|}{ Bank Risk } \\
\hline Bank risk & & 0.005 & & & & 0.005 & O & 0.004 & \\
\hline Bank risk - within auction & & & -0.001 & & & & -0.002 & & -0.003 \\
\hline \multicolumn{10}{|l|}{ Transaction Variable } \\
\hline Highest bid of auction & $0.421 * * *$ & $0.428 * * *$ & $0.472 * * *$ & $0.403 * * *$ & $0.404 * * *$ & $0.410 * * *$ & $0.457 * * *$ & $0.411 * * *$ & $0.457 * * *$ \\
\hline \multicolumn{10}{|l|}{ Relationship } \\
\hline Relationship (trades) & & & & $0.588 * * *$ & & $0.597 * * *$ & $0.598 * * *$ & & \\
\hline Relationship (amount) & & & & & $0.532 * * *$ & & & $0.542 * * *$ & $0.552 * * *$ \\
\hline Other Transaction Variables & Yes & Yes & Yes & Yes & Yes & Yes & Yes & Yes & Yes \\
\hline Bank-Firm Fixed Effects & Yes & Yes & Yes & Yes & Yes & Yes & Yes & Yes & Yes \\
\hline Bank-Time Fixed Effects & Yes & Yes & Yes & Yes & Yes & Yes & Yes & Yes & Yes \\
\hline Observations & 140,837 & 124,635 & 68,524 & 140,169 & 140,169 & 124,049 & 68,204 & 124,049 & 68,204 \\
\hline Adjusted R-squared & 0.318 & 0.324 & 0.351 & 0.352 & 0.349 & 0.359 & 0.388 & 0.355 & 0.384 \\
\hline
\end{tabular}




\section{NOT FOR PUBLICATION}

\section{Addition to Table 7}

Selection of Banks by Firms when Bank Risk Increases Substantially

The table reports OLS regression results of an indicator variable, which is one when a bid is selected and zero otherwise, on control variables using data from January 2005 to June 2010. The data include all auctions where a bid is selected and at least two banks are bidding. A constant is included but omitted. All variables are defined in Appendix A1. Bank risk is used with its value on the day prior to the transaction. The relationship variables are derived over the previous year excluding the current transaction. The time fixed effects are based on month. Change $>5 \%$ above median is a dummy variable which is one when the percentage change of a bank's CDS spread is more than 5 percentage points above the median percentage change of CDS spreads of all sample banks over the same time interval. Increase $>x \%$ is a dummy variable which is one when a bank's CDS spread increases more than $\mathrm{x} \%$ over the specified time interval. In the regressions, these variables are used with their value in the previous period. The crisis period ranges from August 8, 2007 to June 30, 2010. The statistical significance of the results is indicated by $*=10 \%$ level, $* *=5 \%$ level and $* * *=1 \%$ level using heteroscedasticity-robust standard errors clustered at the bank-level.

\begin{tabular}{|c|c|c|c|c|c|c|c|c|c|c|c|c|}
\hline \multirow[t]{3}{*}{ Dependent Variable } & \multicolumn{12}{|c|}{$1=$ Executed bid } \\
\hline & \multicolumn{6}{|c|}{ Total Period } & \multicolumn{5}{|c|}{ Crisis Period } & \multirow[b]{2}{*}{ XII } \\
\hline & I & II & III & IV & $\mathrm{V}$ & VI & VII & VIII & IX & $\mathrm{X}$ & $\mathrm{XI}$ & \\
\hline \multicolumn{13}{|l|}{ Change in bank risk - Week } \\
\hline Change $>5 \%$ above median & 0.004 & & & & & & 0.005 & & & & & \\
\hline $\begin{array}{l}\text { Increase }>20 \% \\
\text { Increase }>70 \%\end{array}$ & & -0.008 & & & & & & -0.006 & & & & \\
\hline \multicolumn{13}{|l|}{ Change in bank risk - Quarter } \\
\hline Change $>5 \%$ above median & & & & 0.004 & & & & & & 0.004 & & \\
\hline Increase $>20 \%$ & & & & & 0.002 & & & & & & 0.002 & \\
\hline Increase $>70 \%$ & & & & & & 0.003 & & & & & & 0.006 \\
\hline \multicolumn{13}{|l|}{ Bank Risk } \\
\hline Bank risk & 0.004 & 0.005 & 0.005 & 0.004 & 0.004 & 0.004 & -0.003 & -0.002 & -0.002 & -0.003 & -0.003 & -0.004 \\
\hline \multicolumn{13}{|l|}{ Transaction Variable } \\
\hline Highest bid of auction & $0.421 * * *$ & $0.421 * * *$ & $0.421^{* * * *}$ & $0.423 * * *$ & $0.424 * * *$ & $0.423 * * *$ & $0.467 * * *$ & $0.467 * * *$ & $0.467 * * *$ & $0.467 * * *$ & $0.467 * * *$ & $0.467 * * *$ \\
\hline \multicolumn{13}{|l|}{ Relationship } \\
\hline Relationship (trades) & $0.595 * * *$ & $0.595 * * *$ & $0.595 * * *$ & $0.600 * * *$ & $0.600 * * *$ & $0.600 * * *$ & $0.604 * * *$ & $0.604 * * *$ & $0.604 * * *$ & $0.604 * * *$ & $0.604 * * *$ & $0.604 * * *$ \\
\hline Other Transaction Variables & Yes & Yes & Yes & Yes & Yes & Yes & Yes & Yes & Yes & Yes & Yes & Yes \\
\hline Bank-Firm Fixed Effects & Yes & Yes & Yes & Yes & Yes & Yes & Yes & Yes & Yes & Yes & Yes & Yes \\
\hline Bank-Time Fixed Effects & Yes & Yes & Yes & Yes & Yes & Yes & Yes & Yes & Yes & Yes & Yes & Yes \\
\hline Observations & 125,916 & 125,916 & 125,916 & 121,192 & 121,192 & 121,192 & 83,183 & 83,183 & 83,183 & 82,333 & 82,333 & 82,333 \\
\hline Adjusted R-squared & 0.366 & 0.366 & 0.366 & 0.367 & 0.367 & 0.367 & 0.387 & 0.387 & 0.387 & 0.386 & 0.386 & 0.386 \\
\hline
\end{tabular}




\section{Addition to Table 8}

\section{Selection of Banks by Firms by Deposit Characteristics}

The table reports OLS regression results of an indicator variable, which is one when a bid is selected and zero otherwise, on control variables using data from January 2005 to June 2010. The data include all auctions where a bid is selected and at least two banks are bidding. A constant is included but omitted. All variables are defined in Appendix A1. Bank risk is used with its value on the day prior to the transaction. The relationship variables are derived over the previous year excluding the current transaction. The time fixed effects are based on month. In Panel A, Extremely high bid is defined as a dummy variable which is one if the highest bank bid is $50 \%$ above the median interest rate of all bids in this auction. Panel A only includes auctions where a bid is selected and at least three banks are bidding. In Panel B, columns I to IV only include auctions with a maturity of one day and columns V to VIII include only auctions with a maturity of more than five days. In Panel C, columns I to IV only include auctions with a notional amount of up to $€ 100$ million and columns V to VIII include only auctions with a notional amount of more than $€ 100$ million. The statistical significance of the results is indicated by $*=10 \%$ level, $* *=5 \%$ level and $* * *=1 \%$ level using heteroscedasticity-robust standard errors clustered at the banklevel.

Panel A: Extremely high bids

\begin{tabular}{|c|c|c|c|c|c|c|c|c|c|}
\hline Dependent Variable & & & & & $=$ Executed & & 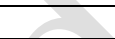 & Y & \\
\hline & $\mathrm{I}$ & II & III & IV & V & VI & VII & VIII & IX \\
\hline Extremely high bid & 0.030 & 0.022 & $0.144 * * *$ & -0.018 & -0.002 & -0.022 & 0.074 & -0.005 & 0.088 \\
\hline Bank Risk & & & & & & & & & \\
\hline Bank risk & & 0.004 & & & & 0.004 & & 0.003 & \\
\hline Bank risk - within auction & & & -0.003 & & & & -0.003 & & -0.004 \\
\hline Transaction Variable & & & & & & & & & \\
\hline Highest bid of auction & $0.413 * * *$ & $0.422 * * *$ & $0.473 * * *$ & $0.396 * * *$ & $0.397 * * *$ & $0.405 * * *$ & $0.460 * * *$ & $0.405^{* * *}$ & $0.460 * * *$ \\
\hline Relationship & & & & & & & & & \\
\hline Relationship (trades) & & & & $0.585 * * *$ & & $0.602 * * *$ & $0.602 * * *$ & & \\
\hline Relationship (amount) & & & & & $0.520 * * *$ & & & $0.538 * * *$ & $0.548 * * *$ \\
\hline Other Transaction Variables & Yes & Yes & Yes & Yes & Yes & Yes & Yes & Yes & Yes \\
\hline Bank-Firm Fixed Effects & Yes & Yes & Yes & Yes & Yes & Yes & Yes & Yes & Yes \\
\hline Bank-Time Fixed Effects & Yes & Yes & Yes & Yes & Yes & Yes & Yes & Yes & Yes \\
\hline Observations & 131,342 & 114,792 & 57,730 & 130,784 & 130,784 & 114,310 & 57,502 & 114,310 & 57,502 \\
\hline Adjusted R-squared & 0.290 & 0.295 & 0.332 & 0.320 & 0.317 & 0.327 & 0.365 & 0.323 & 0.361 \\
\hline
\end{tabular}

Panel B: Deposit maturity

\begin{tabular}{|c|c|c|c|c|c|c|c|c|}
\hline \multirow[t]{3}{*}{ Dependent Variable } & \multicolumn{8}{|c|}{$1=$ Executed bid } \\
\hline & \multicolumn{4}{|c|}{ Overnight } & \multicolumn{4}{|c|}{$>5$ days } \\
\hline & $\mathrm{I}$ & II & III & IV & $\mathrm{V}$ & VI & VII & VIII \\
\hline Bank Risk & & & & & & & & \\
\hline Bank risk & 0.003 & & 0.001 & & $0.011 * * *$ & & $0.011 * * *$ & \\
\hline Bank risk - within auction & & -0.001 & & -0.003 & & 0.008 & & 0.008 \\
\hline Transaction Variable & & & & & & & & \\
\hline Highest bid of auction & .360 & $0.402 * * *$ & $0.360 * * *$ & $0.402 * * *$ & $0.659 * * *$ & $0.701 * * *$ & $0.659 * * *$ & $0.701 * * *$ \\
\hline Relationship & & & & & & & & \\
\hline Relationship (trades) & $0.670 * * *$ & $0.668 * * *$ & & & $0.179 * * *$ & $0.160^{* * *}$ & & \\
\hline Relationship (amount) & & & $0.615 * * *$ & $0.627 * * *$ & & & $0.161 * * *$ & $0.151 * * *$ \\
\hline Other Transaction Variables & Yes & Yes & Yes & Yes & Yes & Yes & Yes & Yes \\
\hline Bank-Firm Fixed Effects & Yes & Yes & Yes & Yes & Yes & Yes & Yes & Yes \\
\hline Bank-Time Fixed Effects & Yes & Yes & Yes & Yes & Yes & Yes & Yes & Yes \\
\hline Observations & 78,419 & 40,697 & 78,419 & 40,697 & 22,799 & 14,436 & 22,799 & 14,436 \\
\hline Adjusted R-squared & 0.343 & 0.363 & 0.340 & 0.359 & 0.520 & 0.584 & 0.520 & 0.584 \\
\hline
\end{tabular}

Panel C: Deposit notional amount

\begin{tabular}{|c|c|c|c|c|c|c|c|c|}
\hline \multirow[t]{3}{*}{ Dependent Variable } & \multicolumn{8}{|c|}{$1=$ Executed bid } \\
\hline & \multicolumn{4}{|c|}{$\leq € 100$ million } & \multicolumn{4}{|c|}{$>€ 100$ million } \\
\hline & I & II & III & IV & $\mathrm{V}$ & VI & VII & VIII \\
\hline \multicolumn{9}{|l|}{ Bank Risk } \\
\hline Bank risk & $0.010 * *$ & & $0.009^{*}$ & & -0.003 & & -0.003 & \\
\hline Bank risk - within auction & & 0.003 & & 0.001 & & -0.012 & & -0.013 \\
\hline \multicolumn{9}{|l|}{ Transaction Variable } \\
\hline Highest bid of auction & $0.401 * * *$ & $0.447 * * *$ & $0.402 * * *$ & $0.447 * * *$ & $0.482 * * *$ & $0.547 * * *$ & $0.480 * * *$ & $0.546 * * *$ \\
\hline \multicolumn{9}{|l|}{ Relationship } \\
\hline Relationship (trades) & $0.625 * * *$ & $0.633 * * *$ & & & $0.393 * * *$ & $0.307 * * *$ & & \\
\hline Relationship (amount) & & & $0.562^{* * *}$ & $0.585^{* * *}$ & & & $0.428 * * *$ & $0.321 * * *$ \\
\hline Other Transaction Variables & Yes & Yes & Yes & Yes & Yes & Yes & Yes & Yes \\
\hline Bank-Firm Fixed Effects & Yes & Yes & Yes & Yes & Yes & Yes & Yes & Yes \\
\hline Bank-Time Fixed Effects & Yes & Yes & Yes & Yes & Yes & Yes & Yes & Yes \\
\hline Observations & 93,385 & 55,128 & 93,385 & 55,128 & 34,009 & 14,593 & 34,009 & 14,593 \\
\hline Adjusted R-squared & 0.366 & 0.393 & 0.361 & 0.388 & 0.381 & 0.432 & 0.383 & 0.433 \\
\hline
\end{tabular}




\section{Addition to Table 9}

\section{Selection of Banks by Firms by Split Deposits}

The table uses data from January 2005 to June 2010 and reports OLS regression results of an indicator variable, which is one when a bid is selected and zero otherwise, on control variables. The data include all auctions where a bid is selected and at least two banks are bidding. All variables are defined in Appendix A1. Bank risk is used with its value on the day prior to the transaction. The relationship variables are derived over the previous year excluding the current transaction. The time fixed effects are based on month. The statistical significance of the results is indicated by $*=10 \%$ level, $* *=5 \%$ level and $* * *=1 \%$ level using heteroscedasticity-robust standard errors clustered at the bank-level.

\begin{tabular}{|c|c|c|c|c|c|c|c|c|}
\hline \multirow[t]{3}{*}{ Dependent Variable } & \multicolumn{8}{|c|}{$1=$ Executed bid } \\
\hline & \multicolumn{4}{|c|}{ Split deposits } & \multicolumn{4}{|c|}{ Non-split deposits } \\
\hline & $\mathrm{I}$ & II & III & IV & $\mathrm{V}$ & VI & VII & VIII \\
\hline \multicolumn{9}{|l|}{ Bank Risk } \\
\hline Bank risk & $-2.2 \mathrm{E}-4$ & & $-1.0 \mathrm{E}-3$ & & $0.009 *$ & & $0.009 *$ & \\
\hline Bank risk - within auction & & -0.007 & & -0.007 & & 0.004 & & 0.002 \\
\hline \multicolumn{9}{|l|}{ Transaction Variable } \\
\hline Highest bid of auction & $0.401 * * *$ & $0.453 * * *$ & $0.402 * * *$ & $0.453^{* * *}$ & $0.449 * * *$ & $0.493 * * *$ & $0.450 * * *$ & $0.494 * * *$ \\
\hline \multicolumn{9}{|l|}{ Relationship } \\
\hline Relationship (trades) & $0.357 * * *$ & $0.368 * * *$ & & & $0.667 * * *$ & $0.652 *$ & & \\
\hline Relationship (amount) & & & $0.276^{* * *}$ & $0.276^{* * *}$ & & & $0.640 * * *$ & $0.626^{* * *} *$ \\
\hline Other Transaction Variables & Yes & Yes & Yes & Yes & Yes & Yes & Yes & Yes \\
\hline Bank-Firm Fixed Effects & Yes & Yes & Yes & Yes & Yes & Yes & Yes & Yes \\
\hline Bank-Time Fixed Effects & Yes & Yes & Yes & Yes & Yes & Yes & Yes & Yes \\
\hline Observations & 79,410 & 43,042 & 79,410 & 43,042 & 47,984 & 26,679 & 47,984 & 26,679 \\
\hline Adjusted R-squared & 0.290 & 0.328 & 0.288 & 0.326 & 0.495 & 0.512 & 0.493 & 0.509 \\
\hline
\end{tabular}




\section{Addition to Table 10}

\section{Selection of Banks by Firms when the Highest Bid is Not Selected}

The table reports OLS regression results of an indicator variable, which is one when a bid is selected and zero otherwise, on control variables using data from January 2005 to June 2010. The data include all auctions where a bid is selected and at least two banks are bidding but exclude all auctions where the highest bid is selected. A constant is included but omitted. All variables are defined in Appendix A1. Bank risk is used with its value on the day prior to the transaction. The relationship variables are derived over the previous year excluding the current transaction. The time fixed effects are based on month. The crisis period in columns V to VIII ranges from August 8, 2007 to June 30, 2010. The statistical significance of the results is indicated by $*=10 \%$ level, ** $=5 \%$ level and $* * *=1 \%$ level using heteroscedasticity-robust standard errors clustered at the bank-level.

\begin{tabular}{|c|c|c|c|c|c|c|c|c|}
\hline \multirow[t]{3}{*}{ Dependent Variable } & \multicolumn{8}{|c|}{$1=$ Executed bid $\mid$ not highest bid selected } \\
\hline & \multicolumn{4}{|c|}{ Total Period } & \multicolumn{4}{|c|}{ Crisis Period } \\
\hline & $\mathrm{I}$ & II & III & IV & $\mathrm{V}$ & VI & VII & VIII \\
\hline \multicolumn{9}{|l|}{ Bank Risk } \\
\hline Bank risk & 0.000 & & -0.001 & & -0.006 & & -0.006 & \\
\hline Bank risk - within auction & & 0.001 & & -0.002 & & -0.008 & & -0.013 \\
\hline \multicolumn{9}{|l|}{ Relationship } \\
\hline Relationship (trades) & $0.821 * * *$ & $0.896^{* * *}$ & & & $0.791 * * *$ & $0.886^{*}=$ & & \\
\hline Relationship (amount) & & & $0.688 * * *$ & $0.791 * * *$ & & & $0.651 * * *$ & $0.791 * * *$ \\
\hline Other Transaction Variables & Yes & Yes & Yes & Yes & Yes & Yes & Yes & Yes \\
\hline Bank-Firm Fixed Effects & Yes & Yes & Yes & Yes & Yes & Yes & Yes & Yes \\
\hline Bank-Time Fixed Effects & Yes & Yes & Yes & Yes & Yes & Yes & Yes & Yes \\
\hline Observations & 38,470 & 16,134 & 38,470 & 16,134 & 29,163 & 10,030 & 29,163 & 10,030 \\
\hline Adjusted R-squared & 0.178 & 0.202 & 0.164 & 0.183 & 0.189 & 0.234 & 0.174 & 0.214 \\
\hline
\end{tabular}




\section{Addition to Table 11}

\section{Bidding Highest in an Auction and Relationship Building}

The table only includes the selected bids from auctions where at least two banks are bidding. Panel A reports OLS regression results of an indicator variable, which is one when the highest bid is selected and zero otherwise, on control variables using data from January 2005 to June 2010. Panel B reports OLS regressions of the deposit spread, defined as deposit interest rate minus the ECB deposit facility interest rate, on control variables using all deposit transactions on the platform since its initiation in the beginning of the 2000's until June 2010. The panel excludes transactions where a firm deposits with a bank more than the $600^{\text {th }}$ time. Further Transaction Variables include the first bid of the auction, the natural logarithm of the number of banks per auction, and the natural logarithm of the notional deposit amount per auction. A constant is included but omitted. All variables are defined in Appendix A1. Bank risk is used with its value on the day prior to the transaction. The relationship variables are derived over the previous year excluding the current transaction. The time fixed effects are based on month. The statistical significance of the results is indicated by $*=10 \%$ level, $* *=5 \%$ level and $* * *=1 \%$ level using heteroscedasticity-robust standard errors clustered at the bank-level.

Panel A: Highest bid selected

\begin{tabular}{|c|c|c|c|c|c|c|c|c|}
\hline \multirow[t]{2}{*}{ Dependent Variable } & & & \multicolumn{4}{|c|}{$1=$ Highest bid selected $\mid$ executed bid } & \multirow{2}{*}{ VII } & \multirow{2}{*}{ VIII } \\
\hline & $\mathrm{I}$ & II & III & IV & $\mathrm{V}$ & VI & & \\
\hline Bank Risk & & & & & & & & \\
\hline Bank risk & -0.005 & & & & -0.006 & & -0.005 & \\
\hline Bank risk - within auction & & 0.005 & & & & 0.005 & & 0.005 \\
\hline Relationship & & & & & & & & \\
\hline Relationship (trade) & & & $-0.149 * *$ & & $-0.137 *$ & $-0.187 * * *$ & & \\
\hline Relationship (amount) & & & & $-0.109 * *$ & & & -0.092 & $-0.130 * * *$ \\
\hline Transaction Variables & Yes & Yes & Yes & Yes & Yes & Yes & Yes & Yes \\
\hline Bank-Firm Fixed Effects & Yes & Yes & Yes & Yes & Yes & Yes & Yes & Yes \\
\hline Bank-Time Fixed Effects & Yes & Yes & Yes & Yes & Yes & Yes & Yes & Yes \\
\hline Observations & 28,343 & 19,253 & 31,562 & 31,562 & 28,184 & 19,142 & 28,184 & 19,142 \\
\hline Adjusted R-squared & 0.323 & 0.268 & 0.314 & 0.313 & 0.326 & 0.273 & 0.324 & 0.271 \\
\hline
\end{tabular}

Panel B: Deposit spread

\begin{tabular}{|c|c|c|c|c|}
\hline Dependent Variable & & 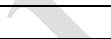 & & \\
\hline & I & II & III & IV \\
\hline Dummy (1=Transactions \#0-100) & $2.651 * * *$ & $2.832 * * *$ & $2.420 * * *$ & $2.850 * * *$ \\
\hline Dummy (1=Transactions \#101-300) & $1.878 * * *$ & $2.086 * * *$ & $2.064 * * *$ & $2.496 * * *$ \\
\hline Dummy (1=Transactions \#301-600) & 1.169 & 1.355 & 1.002 & 1.473 \\
\hline Bank Risk & & & & \\
\hline Bank risk & & & 0.688 & \\
\hline Bank risk-within auction & & & & -0.009 \\
\hline Further Transaction Variables & No & Yes & Yes & Yes \\
\hline Fixed Effects (FE) and Clustering & & & & \\
\hline Bank-Firm Fixed Effects & $\mathrm{Ye}$ & Yes & Yes & Yes \\
\hline Bank-Time Fixed Effects & Yes & Yes & Yes & Yes \\
\hline Observations & 159,801 & 159,801 & 127,393 & 69,790 \\
\hline Adjusted R-squared & 0.902 & 0.902 & 0.902 & 0.898 \\
\hline
\end{tabular}




\section{Addition to Table 12}

\section{Difference between Successful and Unsuccessful Auctions}

The table uses data aggregated to the auction level. It reports OLS regression results of an indicator variable, which is one when a bid is selected and zero otherwise, on control variables using data from January 2005 to June 2010. The data include all auctions where at least two banks are bidding. The control variables are used with their average value on the auction level. Further transaction variables included in the regressions are the logarithm of the number of bidding banks per auction, the difference between the highest and the lowest bid, and the logarithm of the notional deposit amount. A constant is included but omitted. All variables are defined in Appendix A1. Bank risk is used with its value on the day prior to the transaction prior to its aggregation. The relationship variables are derived over the previous year excluding the current transaction prior to their aggregation. The time fixed effects are based on month. The statistical significance of the results is indicated by $*=10 \%$ level, $* *=5 \%$ level and $* * *=1 \%$ level using heteroscedasticity-robust standard errors clustered at the bank-level.

\begin{tabular}{|c|c|c|c|c|}
\hline \multirow[t]{2}{*}{ Dependent Variable } & & \multicolumn{2}{|c|}{$1=$ Executed auction } & \multirow[b]{2}{*}{ IV } \\
\hline & $\mathrm{I}$ & II & III & \\
\hline \multicolumn{5}{|l|}{ Bank Risk } \\
\hline Average bank risk & 0.006 & 0.006 & 0.001 & 0.001 \\
\hline \multicolumn{5}{|l|}{ Relationship } \\
\hline Average relationship (trades) & $1.079 * * *$ & & $1.287 * * *$ & \\
\hline Average relationship (amount) & & $1.033 * * *$ & & $1.225 * * *$ \\
\hline Further Transaction Variables & Yes & Yes & Yes & Yes \\
\hline Average Bank Accounting Variables & Yes & Yes & Yes & Yes \\
\hline Firm Fixed Effects & Yes & Yes & Yes & Yes \\
\hline Time Fixed Effects & Yes & Yes & Yes & Yes \\
\hline Observations & 48,367 & 48,367 & 48,367 & 48,367 \\
\hline Adjusted R-squared & 0.197 & 0.197 & 0.223 & 0.222 \\
\hline
\end{tabular}




\section{Addition to Table 13}

\section{Deposit Amount and Maturity in Future Periods}

The table uses data aggregated to the bank-firm-month level (Panel A and C) as well as the bank-firm-quarter level (Panel B). It reports OLS regression results using data from January 2005 to June 2010. In Panel A, the dependent variable is the logarithm of the total deposit amount a bank receives from a firm on the platform in a month. In Panel B (Panel C), the dependent variable is the logarithm of the total deposit amount a bank receives from a firm on the platform in a quarter (month) times the average deposit maturity of all deposits a bank receives from a firm on the platform in a quarter (month). The data include all auctions where a bid is selected and at least two banks are bidding. A constant is included but omitted. In Panel A and C (Panel B), lagged bank risk is a bank's average CDS spread in the previous month (quarter). In Panel A and C (Panel B), lagged relationship is a bank's average relationship with the firm in the previous month (quarter). In Panel A and C (Panel B), bank characteristics variables are used as stated in the annual report in the year prior to the month (quarter). In Panel A and C (Panel B), the time fixed effects are based on month (quarter). The crisis period in columns V to VIII in both panels ranges from August 8, 2007 to June 30, 2010. The statistical significance of the results is indicated by $*=10 \%$ level, $* *=5 \%$ level and $* * *=1 \%$ level using heteroscedasticity-robust standard errors clustered at the bank-level.

Panel A: Deposit amount

\begin{tabular}{|c|c|c|c|c|c|c|c|c|}
\hline \multirow[t]{3}{*}{ Dependent Variable } & \multicolumn{8}{|c|}{$\log$ (monthly deposit amount from firm) } \\
\hline & \multicolumn{4}{|c|}{ Total Period } & \multicolumn{4}{|c|}{ During Crisis } \\
\hline & $\mathrm{I}$ & II & III & IV & $\mathrm{V}$ & VI & VII & VIII \\
\hline \multicolumn{9}{|l|}{ Bank Risk } \\
\hline Lagged bank risk & & & -0.268 & -0.250 & & & 0.023 & 0.039 \\
\hline \multicolumn{9}{|l|}{ Relationship } \\
\hline Lagged relationship (trades) & $21.664 * * *$ & & $21.631 * * *$ & & $20.125 * * *$ & & $20.149 * * *$ & \\
\hline Lagged relationship (amount) & & $20.304 * * *$ & & $20.263 * * *$ & & $19.138 * * *$ & & $19.172 * * *$ \\
\hline Bank Accounting Variables & Yes & Yes & Yes & Yes & Yes & Yes & Yes & Yes \\
\hline \multicolumn{9}{|l|}{ Fixed Effects (FE) and Clustering } \\
\hline Bank-Firm Fixed Effects & Yes & Yes & Yes & Yes & Yes & Yes & Yes & Yes \\
\hline Firm-Time Fixed Effects & Yes & Yes & Yes & Yes & Yes & Yes & Yes & Yes \\
\hline Observations & 8,867 & 8,867 & 8,333 & 8,333 & 6,453 & 6,453 & 6,150 & 6,150 \\
\hline Adjusted R-squared & 0.373 & 0.367 & 0.377 & 0.370 & 0.405 & 0.401 & 0.407 & 0.403 \\
\hline
\end{tabular}

Panel B: Deposit amount * deposit maturity, on a quarterly basis

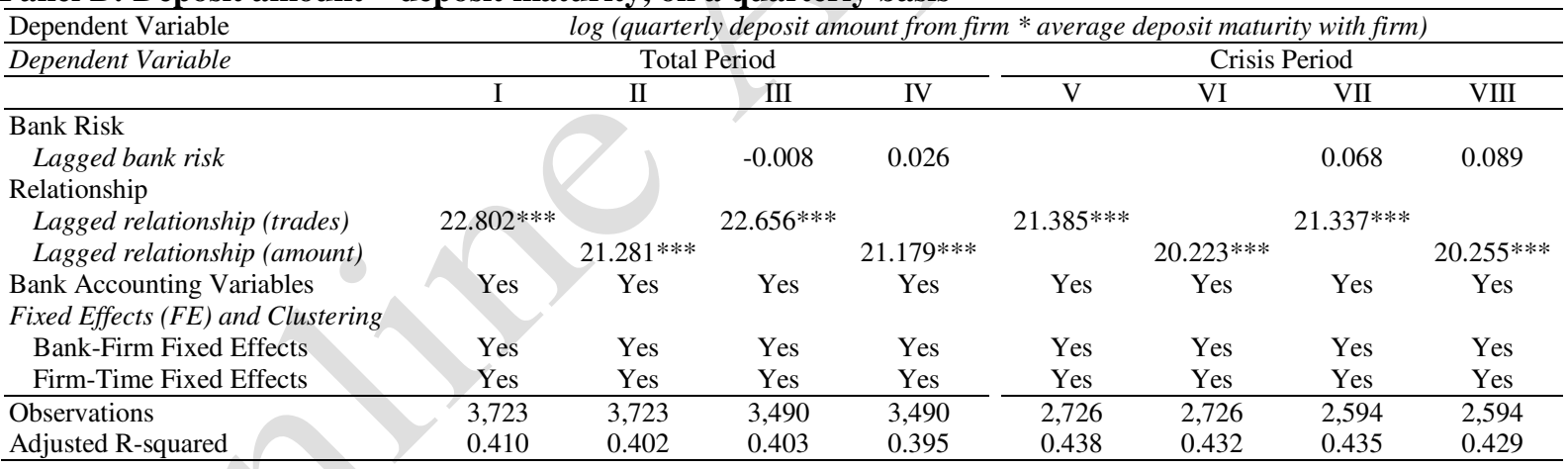

Panel C: Deposit amount * deposit maturity, on a monthly basis

\begin{tabular}{|c|c|c|c|c|c|c|c|c|}
\hline Dependent Variable & & $\log ($ monthl) & deposit am & unt from fir & * average d & eposit matur & ty with firm) & \\
\hline & & Total & Period & & & Crisis & Period & \\
\hline 7 & I & II & III & IV & V & VI & VII & VIII \\
\hline Bank Risk & & & & & & & & \\
\hline Lagged bank risk & & & -0.291 & -0.272 & & & 0.034 & 0.050 \\
\hline Relationship & & & & & & & & \\
\hline Lagged relationship (trades) & $22.616^{* * * *}$ & & $22.562 * * *$ & & $21.110^{* * *}$ & & $21.116^{* * *}$ & \\
\hline Lagged relationship (amount) & & $21.198 * * *$ & & $21.152 * * *$ & & $20.090 * * *$ & & $20.120 * * *$ \\
\hline Bank Accounting Variables & Yes & Yes & Yes & Yes & Yes & Yes & Yes & Yes \\
\hline Fixed Effects (FE) and Clustering & & & & & & & & \\
\hline Bank-Firm Fixed Effects & Yes & Yes & Yes & Yes & Yes & Yes & Yes & Yes \\
\hline Firm-Time Fixed Effects & Yes & Yes & Yes & Yes & Yes & Yes & Yes & Yes \\
\hline Observations & 8,867 & 8,867 & 8,333 & 8,333 & 6,453 & 6,453 & 6,150 & 6,150 \\
\hline Adjusted R-squared & 0.375 & 0.370 & 0.378 & 0.372 & 0.403 & 0.399 & 0.405 & 0.401 \\
\hline
\end{tabular}

